\title{
Development of improved T cell receptor beta variable gene identification technology and its application post hematopoietic stem cell transplantation
}

Jamie Leigh Brewer

West Virginia University

Follow this and additional works at: https://researchrepository.wvu.edu/etd

\section{Recommended Citation}

Brewer, Jamie Leigh, "Development of improved T cell receptor beta variable gene identification technology and its application post hematopoietic stem cell transplantation" (2005). Graduate Theses, Dissertations, and Problem Reports. 2275.

https://researchrepository.wvu.edu/etd/2275

This Dissertation is protected by copyright and/or related rights. It has been brought to you by the The Research Repository @ WVU with permission from the rights-holder(s). You are free to use this Dissertation in any way that is permitted by the copyright and related rights legislation that applies to your use. For other uses you must obtain permission from the rights-holder(s) directly, unless additional rights are indicated by a Creative Commons license in the record and/ or on the work itself. This Dissertation has been accepted for inclusion in WVU Graduate Theses, Dissertations, and Problem Reports collection by an authorized administrator of The Research Repository @ WVU.

For more information, please contact researchrepository@mail.wvu.edu. 


\title{
Development of improved T cell receptor beta variable gene identification technology and its application post hematopoietic stem cell transplantation.
}

\author{
Jamie Leigh Brewer \\ Fulfillment of the Requirements for the Degree of \\ Doctor of Philosophy \\ In \\ Microbiology, Immunology, and Cell Biology \\ Solveig G. Ericson, M.D., Ph.D., Chair \\ Christopher Cuff, Ph.D. \\ Laura F. Gibson, Ph.D. \\ Daniel Lewis, Ph.D. \\ Muzaffar Qazilbash, M.D.
}

Dissertation Submitted to the School of Medicine at West Virginia University in Partial

Department of Microbiology, Immunology, and Cell Biology

Morgantown, West Virginia

2005

Keywords: T cell, T cell receptor, allogeneic hematopoietic stem cell transplant, PCR Copyright 2005 


\section{ABSTRACT \\ Development of improved T cell receptor beta variable gene identification technology and its application post hematopoietic stem cell transplantation}

\section{Jamie Leigh Brewer}

Much has yet to be understood about the role of specific families of $T$ lymphocytes in the post human hematopoietic stem cell (HSC) transplant environment. Prior work in the field has identified $\mathrm{T}$ cells based upon the expression of their $\mathrm{T}$ cell receptor beta variable regions (TCRBV). In this investigation we developed a comprehensive panel of oligonucleotides that can be used to determine the expression of all 91 alleles of the human TCRBV regions using real time PCR technology. Application of this technology to peripheral blood samples collected weekly from allogeneic peripheral blood stem cell transplant patients yielded the following findings: (1) specific TCRBV families are associated with the reactivation of cytomegalovirus (CMV) post HSC transplant with many of these same TCRBV families also being associated with the occurrence of GVHD, (2) the TCRBV repertoire engrafts in the recipient with a profile more similar to that found in the donor as opposed to that found in the recipient prior to transplant, and (3) the similar immunosuppressive agents, cyclosporin A (CSA) and tacrolimus (FK506), differentially alter the TCRBV repertoire with their administration, a difference which can not be attributed to a divergent inhibition of calcineurin or IL-2 production by CSA or FK506. 


\section{ACKNOWLEDGEMENTS}

I thank members of the West Virginia University Mary Babb Randolph Cancer Center's Blood and Marrow Transplantation and Hematological Malignancy Program who aided in the consenting of participants and collection of samples for our study. A sincere thank you is extended to the patients who participated in our study and who, despite the rigors of their transplant process, were eager to help further our understanding of blood and marrow transplantation. The author would also like to thank Ms. Alyssa Henderson for her constant support of this project throughout her tenure in my laboratory. The author would like to thank Geoff Routh, Ph.D., for his outstanding advice and technical assistance with the amplification reactions and Scott Stuckman for his helpful advice with the IOTest ${ }^{\circledR}$ antibody kit. I thank the laboratory of Dr. Kenneth Landreth (West Virginia University, Morgantown, WV) for their immeasurable advice pertaining to nucleic acid amplification reactions. I also thank Dr. David Weissman (National Institute for Occupational Safety and Health, Morgantown, WV) for graciously permitting my usage of his thermalcycler equipment. The author would like to thank Dr. Kathleen Brundage (West Virginia University, Morgantown, WV) and the laboratory of Dr. John Barnett (West Virginia University, Morgantown, WV) for their assistance and guidance with the in vitro Jurkat experiments. The author would also like to express her gratitude to Dr. Cynthia Cunningham (West Virginia University, Morgantown, WV) for her help with the 7-AAD and CFSE data acquisition. In addition, the author would like to thank Dr. James Harner, Dr. Daniel Chilko, Ms. Bixia Li, and Dr. Michael Webb for their outstanding advice and expertise with statistical calculations. The author also thanks the Institute for Scientific Research, Inc. (Fairmont, WV) and James Dilmore, Ph.D. (Reed Smith, Pittsburgh, PA) for their help in securing both U.S. and foreign patent protection of my TCRBV technology. This work was supported with funding provided by the Department of Medicine, West Virginia University, Morgantown,

WV, and NIH grant number 5 P20 RR16440-02. 


\section{TABLE OF CONTENTS}

ABSTRACT

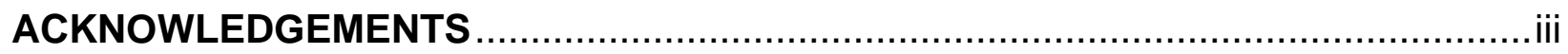

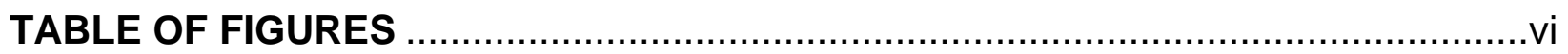

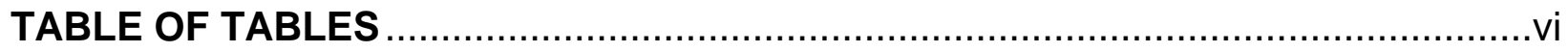

REVIEW OF LITERATURE ............................................................................... 1

The History of Hematopoietic Stem Cell Transplantation ........................................ 2

Types of Hematopoietic Stem Cell Transplantation ............................................ 2

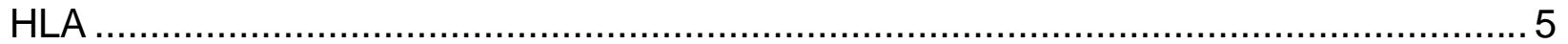

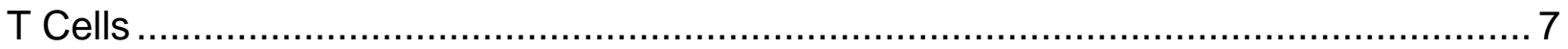

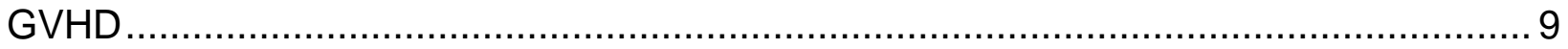

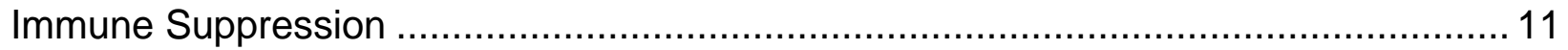

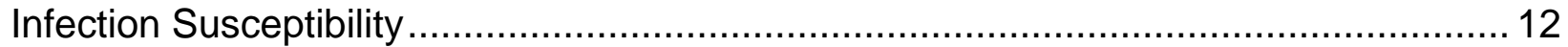

Identification of T Cells Involved in GVHD Through TCRBV Analysis ......................... 12

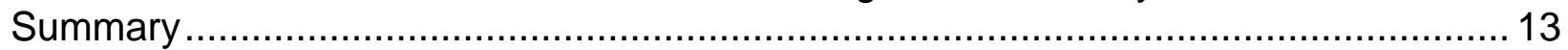

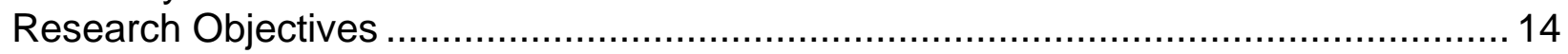

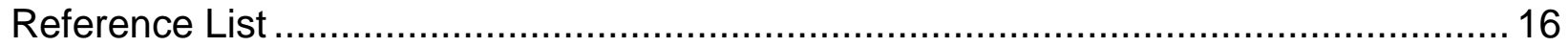

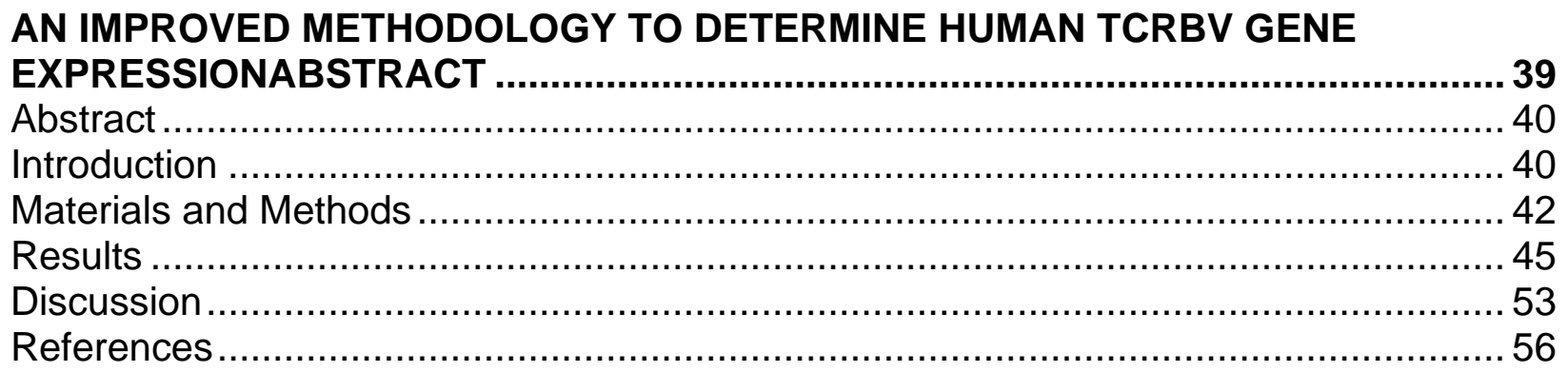

SIMILARITY IN REPERTOIRE OF T CELLS ASSOCIATED WITH OCCURRENCES OF CMV REACTIVATION AND GVHD POST HUMAN HEMATOPOIETIC STEM CELL

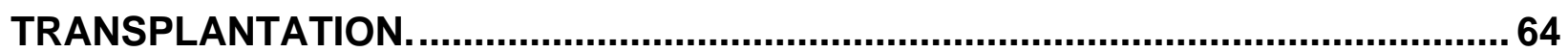

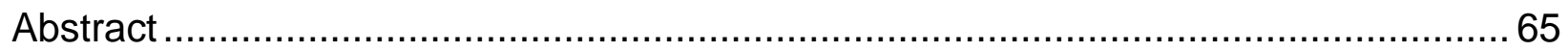

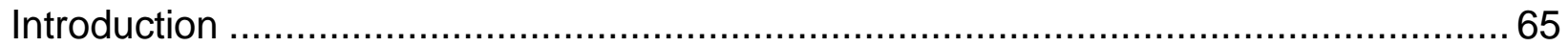

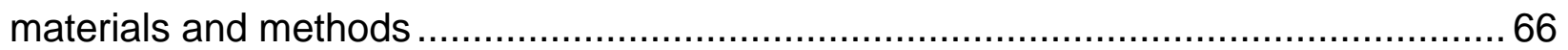

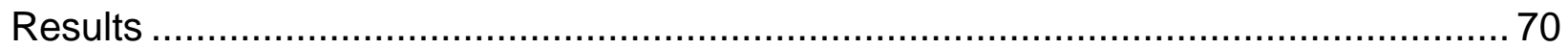

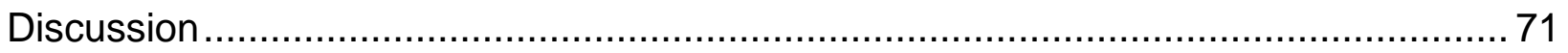

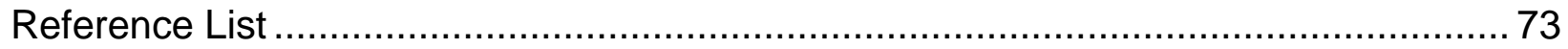

ENGRAFTMENT OF T CELL RECEPTOR (TCR) REPERTOIRE IN MYELOABLATED ALLOGENEIC HEMATOPOIETIC STEM CELL RECIPIENTS MIMICS DONOR TCR

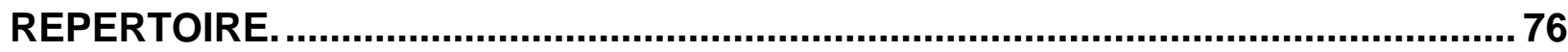

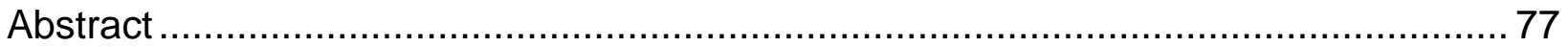




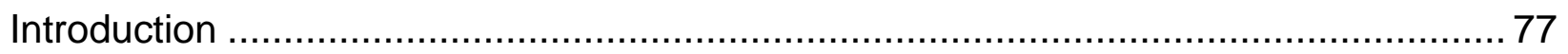

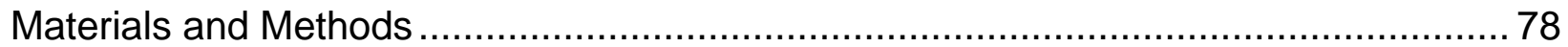

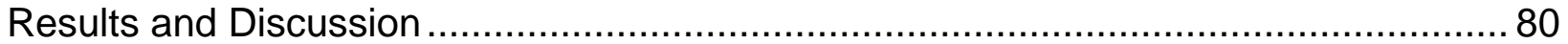

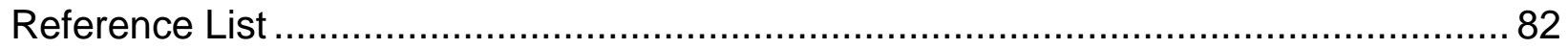

CYCLOSPORINE A (CSA) AND TACROLIMUS (FK506) DIFFERENTIALLY ALTER T

CELL RECEPTOR (TCR) EXPRESSION IN VIVO............................................ 83

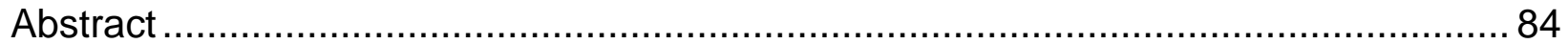

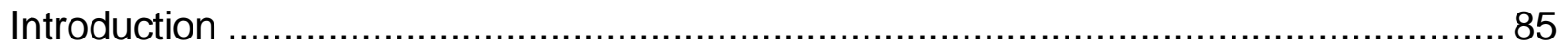

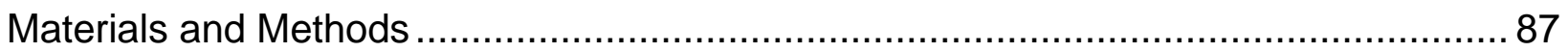

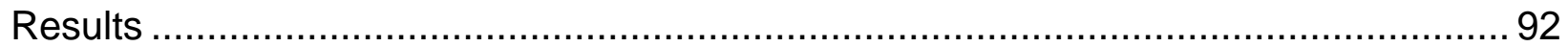

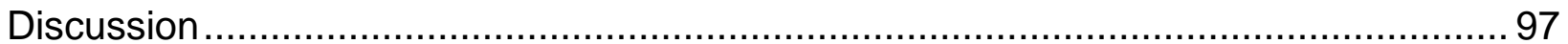

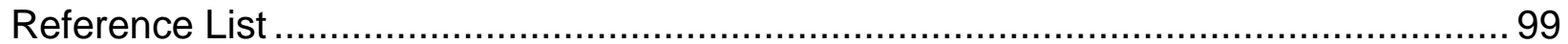

GENERAL CONCLUSIONS AND DISCUSSION ............................................ 102

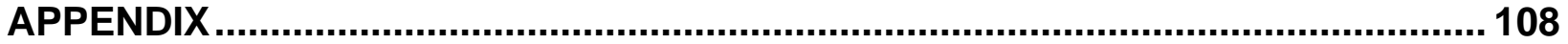

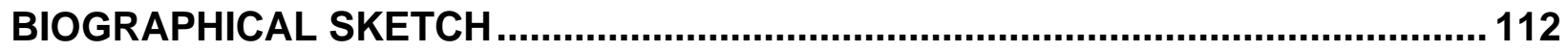

CUMULATIVE REFERENCES ......................................................................... 117 


\section{TABLE OF FIGURES}

Figure 1: Gene structure of the human major histocompatibiltiy complex (MHC)......... 6

Figure 2: $T$ cell receptor (TCR) gene rearrangement ....................................... 7

Figure 1: iCycler fluorescence readings during amplification of TCRBV1. ................. 49

Figure 2: Amplification efficiency analysis. ................................................. 50

Figure 3: Relative TCRBV mRNA expression levels of three human peripheral blood

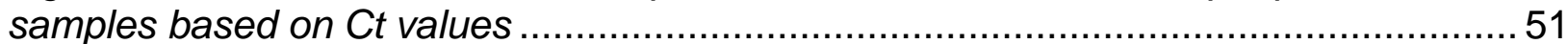

Figure 4: TCRBV1 expression level changes in a hematopoietic stem cell transplant

recipient before and after transplant. 52

Figure 1: Abbreviated schematic of the signaling pathway activated by engagement of the $T$ cell receptor (TCR) and its inhibition by CSA and FK506............................ 85

Figure 2: Effects of CSA and FK506 on Jurkat cell viability as measured by 7-AAD exclusion.

Figure 3: Effects of CSA and FK506 on Jurkat cell proliferation as determined by CFSE

cellular membrane labeling. 94

Figure 4: Effects of CSA and FK506 on IL-2 secretion by Jurkat cells as measured by ELISA.

\section{TABLE OF TABLES}

Table 1: TCRBV primer panel organization.

Table 2: Peripheral blood composition of donor samples....................................... 48

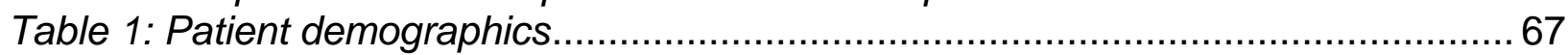

Table 2: Increased expression of specific families of TCRBV is associated with cytomegalovirus (CMV) reactivation and Graft-versus-Host Disease (GVHD) post peripheral blood stem cell transplant. ........................................................... 71

Table 1: patient demographics ........................................................ 79

Table 2: The TCRBV repertoire engrafts with a phenotype similar to that present in the donor.

Table 1: In vivo TCRBV expression changes in response to increases in (a) FK506 dose concentrations and (b) CSA dose concentrations. 


\section{CHAPTER 1}

\section{REVIEW OF LITERATURE}




\section{The History of Hematopoietic Stem Cell Transplantation}

Many advancements in the field of hematopoietic stem cell transplantation were borne from the seemingly unrelated birth of nuclear technologies. With the development of atomic technologies and the potential of nuclear warfare, the effects of irradiation on biological systems became an area of imminent interest ${ }^{1}$. This resulted in a series of experiments conducted over the past fifty years and has greatly increased our understanding of hematopoietic stem cell transplant and the immunological mechanisms that are so critical to its success.

The modern epoch of bone marrow transplantation was pioneered by Lorenz in 1951 when he demonstrated that mice could be protected against lethal irradiation by intravenous infusion of bone marrow ${ }^{2}$. This discovery quickly brought about the notion that hematological malignancies could potentially be cured through irradiation and subsequent marrow grafting. Barnes, et al., showed that murine leukemia could be successfully treated using sub-lethal doses of irradiation followed by the infusion of healthy marrow ${ }^{3}$. The following year, the first reports detailing similar clinical trials in humans were made, describing the immediate rescuing from radiation-induced pancytopenia in cancer patients by marrow infusion ${ }^{4,5}$. In 1959, Mathe et al., attempted bone marrow transplantation in humans on a larger scale when they tried to rescue six victims of a radiation accident in Vinca, Yugoslavia, by transplanting allogeneic bone marrow ${ }^{6}$. This group continued trying to use bone marrow transplantation as treatment for hematologic malignant conditions, however, it was not until 1963 that they reported the first case of a patient surviving beyond a year. While this patient remained leukemiafree, severe graft-versus-host disease (GVHD) reactions were documented, the first of such, and the patient succumbed to infection 20 months post-transplant ${ }^{7}$.

\section{Types of Hematopoietic Stem Cell Transplantation}

There are three primary types of hematopoietic stem cell transplants depending upon the stem cell source and the identity of the donor. These are termed autologous, allogeneic, and syngeneic transplants. The first type, autologous transplant, describes the process where an individual serves as his/her own stem cell source. In order for an autologous stem cell transplant to be successful, the individual's marrow must be virtually disease free prior to harvesting. An example of the use of this type of transplant 
is one in which a patient must undergo intensive treatment directed at his/her tumor, which, as a consequence, would inadvertently cause destruction to his/her hematopoietic system. After the high-dose tumor therapy, the patient can then be infused with the previously collected stem cells to rescue his/her hematopoietic system. Autologous transplants are now most frequently used for hematologic malignancies such as lymphomas. Advantages to autologous transplantations are that there is no need to locate a suitable stem cell donor as well as a decreased risk of treatmentrelated mortality. Such transplants, however, have a risk of tumor cell contamination in the graft. Additionally, autologous transplants cannot be used in the treatment of inherited non-malignant hematopoietic diseases or acquired marrow failure states, such as aplastic anemia ${ }^{8}$.

The second major type of hematopoietic stem cell transplant, termed an allogeneic transplant, is one in which the stem cell donor is separate from the recipient. The donor must be genetically matched to the recipient but the two can either be related or unrelated. Advantages of this type of transplant are that there is a low risk of the graft being contaminated with malignant cells and it can successfully be used in treating both malignant and non-malignant diseases of the hematopoietic system. An additional advantage to allogeneic transplant is the possible destruction of residual recipient tumor cells by the infused donor-derived cells, an occurrence termed graft-versus-tumor effect. Despite these advantages, however, there is often great difficulty in finding an appropriate donor and there is a greater increase, compared to autologous transplants, of post-transplant complications, such as graft-versus-host disease ${ }^{8}$.

The third major type of hematopoietic stem cell transplant is one in which the donor and recipient are genetically identical, such as the case that occurs when the recipient and donor are identical twins, and is termed a syngeneic transplant. Post transplant complications tend to be diminished in this setting, compared to a nonidentical allogeneic transplant, but while the majority of patients may have a sibling, it is relatively uncommon for the sibling to be an identical twin ${ }^{8}$.

Traditionally, hematopoietic stem cells (HSC) have been harvested from bone marrow through extraction at the iliac crests. Recent advancements in transplantation technology, though, have permitted the mobilization of hematopoietic stem cells from 
the bone marrow environment to the peripheral circulation through the use of growth factors such as granulocyte colony stimulating factor (G-CSF) ${ }^{9-13}$. HSC comprise only a small fraction of the total number of cells in the bone marrow, with a rate of approximately one $\mathrm{HSC} / 10,000$ total bone marrow cells and the number of HSC circulating in the peripheral blood is an exceedingly rare event ${ }^{14}$. After G-CSF administration, however, the frequency of HSC in the peripheral blood is increased two to five-fold greater than that found in the bone marrow ${ }^{15}$. Mobilized HSC can then be harvested from the peripheral blood by a pheresis procedure. A dose of at least five million $\mathrm{HSC} / \mathrm{kg}$ recipient weight has been reported to be the ideal dose to achieve engraftment ${ }^{16}$.

While multiple collections may be required in order to achieve the necessary number of stem cells for transplant using the G-CSF mobilization technique, there is a low toxicity profile associated with G-CSF administration in humans ${ }^{10-13}$. The side effects are generally limited to bone pain and general influenza-like symptoms and there have been no documented reports of termination of G-CSF administration to healthy donors due to its side effects. Thrombocytopenia, or the reduction in platelet number, is frequently observed post-pheresis in G-CSF mobilized donors. This reduction, as well as any bone discomfort, is generally reversed within 48 hours of cessation of drug administration. On the other hand, while bone marrow harvests require no mobilization therapies and can often be done in a single one-day collection, the pain associated with bone marrow harvests may take 2 to 4 weeks to subside ${ }^{17,18}$. In addition, various studies have reported a decreased time for reconstitution of the immune system, less transplant-related toxicities and mortalities, and a decreased rate of GVHD occurrence in peripheral blood stem cell recipients compared to bone marrow recipients ${ }^{19-23}$.

The benefits of peripheral blood stem cell harvesting, compared to bone marrow harvesting, have resulted in peripheral blood stem cell transplantation becoming much more frequently used compared to bone marrow transplantation. HSC have also been collected from umbilical cord blood and used successfully in allogeneic transplantation. While cord blood HSC have decreased alloreactive potential compared to their counterparts isolated from more mature donors, cord blood stem cells exhibit a delayed 
reconstitution of the hematopoietic system, thereby limiting their usage in hematopoietic stem cell transplantation ${ }^{24-30}$.

In allogeneic transplants the conditioning regimen the recipient receives prior to transplant is highly dependent upon the type of disease the patient has as well as how aggressively it behaves ${ }^{31}$. There are three main objectives to the treatment. The primary objective is to eradicate the underlying hematological disease in the recipient. The second objective is to suppress the recipient's immune system to decrease the risk of the recipient rejecting the donor's stem cells. The third objective in using a conditioning regimen pre-transplant is to create space in which the donor's stem cells can engraft and growth can be accommodated ${ }^{32}$. While the amount of time required for immune reconstitution post hematopoietic stem cell transplant varies depending upon parameters such as the type of transplant, conditioning regimens, and immunosuppressive therapies, $\mathrm{CD}^{+} \mathrm{T}$ cell counts tend to recover to normal values within the first month post transplant with a prolonged deficiency of $\mathrm{CD} 4^{+} \mathrm{T}$ cell counts often seen six to twelve months post transplant, leading to the characteristic inversion of the CD4:CD8 ratio observed post transplant ${ }^{33-37}$.

\section{HLA}

Based on experiments initially performed in mice ${ }^{38}$ antigenic principles underlying cellular transplantation began to be established. Such experiments led to the recognition of what became termed the $\mathrm{H} 2$ transplantation antigen system ${ }^{39}$ in mice and the HLA system in humans ${ }^{40}$. The human leukocyte antigen (HLA), also termed the major histocompatibility complex (MHC) forms a complex which is expressed on the cellular surface. The principle function of this molecule is to present peptides (from either self or non-self origin) to T lymphocytes, a vital component to the immune system. By doing so, the $T$ lymphocytes are able to distinguish self versus non-self. An illustration of this principle is afforded by examining what occurs during a viral infection: if a cell is infected with a virus, pieces of viral proteins (non-self) are loaded into the MHC molecule and presented on the surface of the infected cell. The interaction of a circulating $\mathrm{T}$ cell with this (non-self) MHC molecule can activate the T cell, causing it to destroy the infected cell, thereby limiting the spread of infection. The same is true in the setting of transplantation. T cells in the donor graft can recognize cells within the 
recipient's body as non-self, eliciting devastating immune reactions. This is the premise of a serious post-transplant complication called graft-versus-host disease (GVHD) ${ }^{41}$.

There are three classes of HLA (or MHC) genes, termed class I, class II, and class III genes, with all three being located on chromosome 6 in humans. The names HLA-A, HLA-B, and HLA-C are given to the human MHC class I genes while the MHC class II genes are identified as HLA-DR, HLA-DP, and HLA-DQ. The products of these $\mathrm{MHC}$ class I genes are expressed on the surface of nearly all cells within the human body while the expression of the MHC class II genes is restricted to antigen presenting cells and thymic epithelium. Classically, MHC class I proteins present endogenous antigen (or peptide) to $\mathrm{CD}^{+} \mathrm{T}$ cells while the MHC class II proteins present exogenous antigen (or peptide) to $\mathrm{CD}^{+} \mathrm{T}$ cells. The final class of genes, those located within the MHC class III region, encode various immunologically relevant proteins such as complement and the tumor necrosis factor cytokines ${ }^{42}$.

\section{Gene structure of the human MHC- chromosome 6}

HLA-

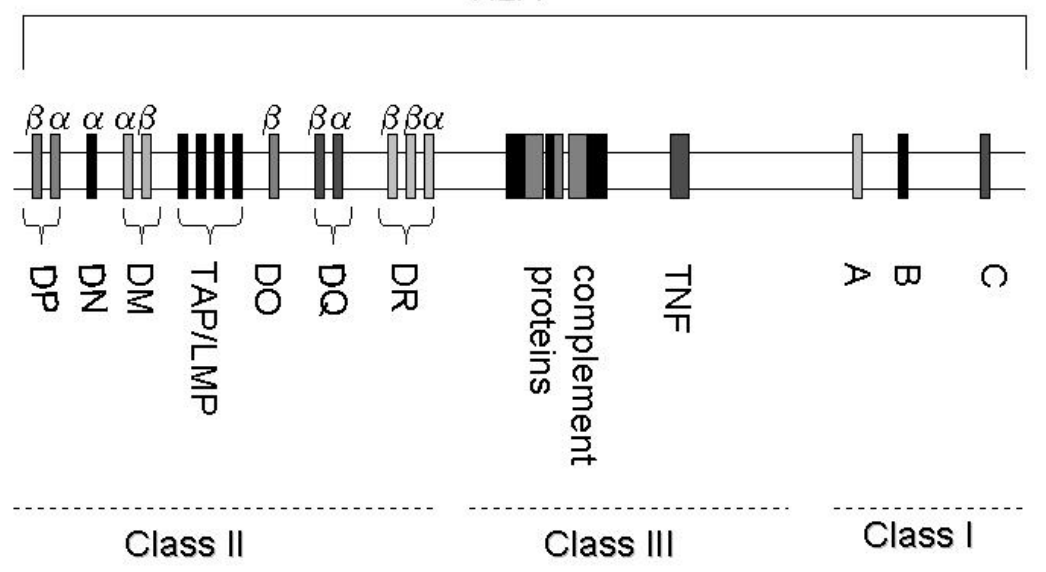

Figure 1: Gene structure of the human major histocompatibiltiy complex (MHC)

The HLA genes are expressed in a co-dominant fashion and are highly polymorphic ${ }^{43}$. In terms of their importance in hematopoietic stem cell transplantation, matching at the MHC class I HLA-A and HLA-B loci was given priority as previously there had been a lack of reagents available to accurately determine the HLA-C 
genotype. Due to the advancements of molecular biology, however, such discrimination is now possible. In fact, recent reports have been made concerning the importance of HLA-C matching in hematopoietic stem cell transplantation ${ }^{44-46}$. As it relates to the MHC class II molecules, allelic mismatching of the donor and recipient at the HLA-DR loci was the first to be shown to be associated with an increase in graft-versus-host disease reaction ${ }^{47}$. The importance of HLA-DQ matching is also becoming more apparent ${ }^{48}$. However, like its MHC class I counterpart (HLA-C), mismatching at the HLA-DQ locus has yet to become a basis for donor exclusion. The role of HLA-DP in transplantation has remained rather controversial and is also not typically evaluated when searching for an appropriate donor ${ }^{49}$. In summary, the common practice of HLA matching in related donor and recipient has remained matching of the HLA-A, HLA-B, and HLA-DR loci, although typing of additional loci is commonly performed when an unrelated donor is being considered. Likewise, HLA matching is typically performed using serological methods when the donor is related and by molecular analyses when the donor and the recipient are not related.

\section{T Cells}

On the converse side of the MHC molecule is the T cell, whose interaction with the $\mathrm{MHC}$ molecule is mediated through the $\mathrm{T}$ cell receptor (TCR). T lymphocytes originate in the bone marrow from a lymphoid progenitor cell and migrate to the thymus as immature cells. The thymus provides a unique microenvironment in which the $\mathrm{T}$ lymphocyte rearranges its receptor genes (chromosome 14, TCR alpha genes and chromosome 7, TCR beta

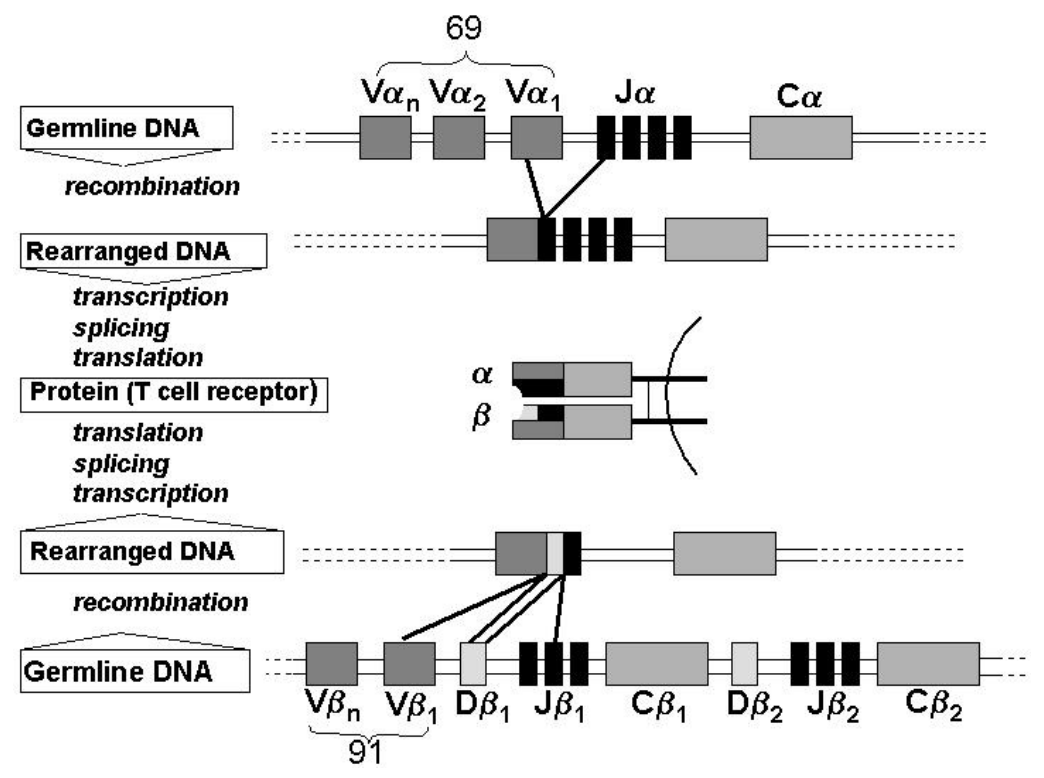

Figure 2: $T$ cell receptor (TCR) gene rearrangement 
genes ${ }^{50}$ ) and matures. T cell receptor (TCR) gene rearrangement occurs in the sub capsular region of the thymus with rearrangement of the heavy chain (or beta chain) genes occurring prior to rearrangement of the light chain (or alpha chain) genes. Within the $T$ cell receptor beta chain locus, a diversity (D) segment is randomly paired with a joining $(J)$ segment. This DJ unit is then rearranged with a variable (V) segment to form a VDJ segment. The constant (C) region exon is then spliced to the VDJ segment to generate the message, which is translated into the $\mathrm{T}$ cell receptor beta chain protein. Beta chain gene rearrangement is followed by rearrangement of the TCR alpha chain, which occurs in the same manner as for the heavy chain. However, as there is no diversity region in the light chain, rearrangement of the variable and joining segments is followed by the $\mathrm{VJ}$ pairing with a constant (C) segment ${ }^{50-52}$.

After the heavy and light chain rearrangements occur, the $T$ cell begins to undergo maturation and moves deeper into the thymus. In the cortex of the thymus the immature cells undergo positive selection where only those developing cells that recognize antigens presented by self-MHC molecules can mature. Those $\mathrm{T}$ cells that do not recognize antigen in the context of a self-MHC molecule are deleted by apoptosis. As the positively selected thymocytes move into the cortico-medullary junction of the thymus they undergo negative selection where those that recognize self-antigens too well are deleted. Negative selection helps to remove auto-reactive $T$ cells from the repertoire. Finally, those thymocytes that have survived both positive and negative selection exit through the medulla of the thymus and enter the peripheral circulation where they traffic through secondary lymphoid organs monitoring the body through $T$ cell receptor:peptide:MHC interactions ${ }^{50-52}$. The significance of the wide variety of MHC molecules (more than fifty alleles at each of the HLA-A, HLA-B, and HLA-DR loci identified ${ }^{53}$ ) and possible TCR rearrangements (24 million ${ }^{54}$ ) is critical to the ability of an individual's immune system to respond to a wide variety of pathogens.

With an understanding of the molecular interaction between the MHC molecule and the TCR, the importance of T cells in the post hematopoietic stem cell transplant setting becomes clearer. Investigations into these reactions and their role in graft rejection and graft-versus-host disease were made as early as $1963^{7,55}$. 


\section{GVHD}

Hematopoietic stem cell transplant offers patients a potential for recovery from otherwise lethal conditions. However, associated with this possibility is the threat of graft-versus-host disease (GVHD), a reaction where the transplant recipient's tissue is attacked and destroyed by the infused donor cells. GVHD-like reactions have been observed in mice that had been treated with allogeneic marrow after irradiation. While these mice recovered from their marrow ablation, the mice died from what was termed "secondary disease", now known as graft-versus-host disease ${ }^{41}$, a condition marked by weight loss, diarrhea, and liver and skin changes ${ }^{56,57}$.

In 1957, such observations in mice led Billingham to establish criteria essential for the development of graft-versus-host disease. The first of these criteria is that the graft must contain immunologically competent cells. Secondly, the recipient of this graft must not be able to mount an immune response against these transplanted cells, which would lead to their ultimate destruction. Finally, the recipient must also express antigens that are not present in the donor graft ${ }^{58}$.

Billingham's first requirement was further understood when in 1962, Gowen identified the cells responsible for GVHD as small lymphocytes ${ }^{59}$, but it was not until 25 years after these first observations that the "immunologically competent cells" were actually identified as T lymphocytes ${ }^{60}$. In 1986 Kernan demonstrated a direct correlation between the severity of GVHD and the number of donor T cells transfused 67 . Attempts have been made to T-cell deplete grafts (ex vivo) prior to transplant which decreases the risk of GVHD, and to then use "add-backs" of donor lymphocytes post transplant in order to promote the graft-versus-tumor effect ${ }^{61-79}$. The complete removal of $\mathrm{T}$ cells from the graft, however, has been shown to cause an increase in graft failure and is, therefore, not a practical option ${ }^{80,81}$.

Billingham's second requirement of the recipient being devoid of immunocompetent cells is typically not of great concern in hematopoietic stem cell transplantation as recipients classically receive intense immunosuppressive treatments in order to prevent the recipient-mediated rejection of the donor cells ${ }^{82-84}$. 
With the discovery of the MHC genes and the role that they play in transplantation, an increased understanding of Billingham's third requirement was achieved. As previously discussed, these MHC molecules are necessary for activation of $T$ cells, in both autologous and allogeneic transplant settings ${ }^{85}$. In allogeneic transplants the matching of the donor and recipient's HLA antigens is one of the foremost criteria in selecting an appropriate hematopoietic stem cell donor. It has been observed, though, that even with matching of these antigens, GVHD reactions can still occur ${ }^{86}$ and have been attributed to what have been termed minor histocompatibility antigens.

Minor histocompatibility antigens, or mHA, have been defined as a non-MHC locus that can elicit allogeneic tissue rejection ${ }^{87,88}$. Minor histocompatibility antigens are inherited and are not necessarily in close proximity to the HLA genes ${ }^{89}$. It has been shown that certain MHC present specific $\mathrm{mHA}^{90,91}$ and specific $\mathrm{mHA}$ elicit responses from specific TCRBV ${ }^{92}$. There have been seventeen minor histocompatibility antigens identified thus far, with the expression of twelve of these being restricted to cells of the hematopoietic lineage ${ }^{91,93,94}$. At the present time, while it is known that $\mathrm{mHA}$ differences can contribute to GVHD, it is difficult to predict the outcome of a hematopoietic stem cell transplant based upon identification of these minor histocompatibility antigens ${ }^{95,96}$.

One model describes the development of GVHD as occurring in two phases: the afferent and efferent phases. The afferent phase consists of the damage incurred to the recipient both by the pre-transplant conditioning regimens (chemotherapy/radiation) as well as by the activation of the donor T cells. It has been shown that the conditioning regimens cause damage to and activate tissues within the recipient, including the tissue of the gastrointestinal tract as well as the liver ${ }^{97-100,}$. Such damage results in the release of LPS and inflammatory cytokines, such as IL-1, tumor necrosis factor (TNF) alpha, and interferon (IFN) gamma, from the activated tissues which causes the subsequent activation of host antigen presenting cells ${ }^{23,101-112}$. Further complicating these circumstances is the fact that LPS and IFN gamma can act in a synergistic fashion, additionally increasing the levels of pro-inflammatory cytokines such as TNF alpha ${ }^{113}$. In addition it has been shown that the administration of antagonists to LPS, as well as to the receptors for these inflammatory cytokines, has ameliorated the effects of GVHD 
$103,105,110,114$. The important role of LPS in GVHD is also supported by the observation that pathogen-free mice have reduced incidence of GVHD after allogeneic transplant 115,116

The efferent stage of GVHD is comprised of the actual destruction of the recipient tissues by activated $T$ lymphocytes responding to allogeneic antigens ${ }^{117}$. A combination of the afferent and efferent stages contribute to the devastation seen in GVHD.

GVHD can present itself in two forms, acute and chronic. Acute GVHD presents within the first 100 days post-transplant whereas the chronic form appears post day 100. The pathology of the two forms show similarities, however ${ }^{41}$.

There are four grades of acute GVHD: I-IV, with IV being the most severe. While the development of GVHD grade I or II is associated with an increased risk of developing GVHD grade III or IV, little morbidity is associated with GVHD grade I. However, much greater levels of morbidity are seen with the progression of GVHD to grades II and III, and grade IV GVHD represents a life threatening condition ${ }^{41}$.

In acute GVHD the primary target organs are the skin, gastrointestinal tract, and liver, with the skin being the most easily observed and often first diagnosed target organ. In the skin, GVHD presents as erythema and rash, commonly located on the palms and soles initially, but can spread to involve the rest of the body. In severe situations, the skin may actually become desquamated (grade IV). In terms of its effect on the gastrointestinal tract and liver functioning, symptoms include nausea, vomiting, diarrhea and hyperbilirubinemia. In each instance, with increased severity of these symptoms or worsening laboratory findings, the higher the grade of GVHD ${ }^{41}$.

\section{Immune Suppression}

Allogeneic hematopoietic stem cell transplant recipients are routinely given immunosuppressive agents to facilitate engraftment and decrease the risk of developing GVHD post transplant. Cyclosporin A (CSA), tacrolimus (FK506), and methotrexate, are examples of such agents. CSA and FK506 have similar mechanisms of action, which is to bind to cyclophilin or FK binding protein (FKBP), respectively; the resulting drug-

protein complexes inhibit calcineurin activity ${ }^{118-128}$. The protein calcineurin is directly involved in the transcription of cytokines, such as IL-2. Through the administration of 
CSA or FK506 it is possible to inhibit expansion of allo-reactive T cells and their reactions post transplant. CSA and FK506 treatment is begun one day before transplant $(d-1)$ and continues throughout the post transplant period.

The mechanism of methotrexate, pulses of which the patients receive as part of standard GVHD prophylaxis, is through the inhibition of dihydrofolate reductase, the enzyme responsible for purine and pyrimidine synthesis, which leads to the suppression of $\mathrm{T}$ cell activation and adhesion molecule expression ${ }^{129}$. Methotrexate infusions are administered on days 1, 3, 6, and 11 post-transplant as standard GVHD prophylaxis.

While immunosuppressive agents such as these help to prevent graft rejection and GVHD, such suppression makes it difficult for the patient to mount immune responses against invading pathogens and also makes the patient more susceptible to the reactivation of latent infections, such as cytomegalovirus.

\section{Infection Susceptibility}

After hematopoietic stem cell transplant patients are highly susceptible to bacterial, viral, and fungal infections. To decrease the risk of overwhelming infections post-transplant, patients receive prophylactic antibiotics. Use of prophylactic anti-fungal agents, such as fluconozole, decreases the occurrence of fungal infections, but in spite of the use of prophylactic antifungal therapy, patients can develop fungal infections including those attributed to Candida and Aspergillus species ${ }^{130}$. Examples of bacterial infections that are commonly observed post transplant include both gram positive (Staphyloccocus, Enterococcus, Clostridium, and Corynebacterium) and gram negative bacteria (Haemophilus and Escherichia). As previously mentioned, reactivation of latent cytomegalovirus (CMV) is a common occurrence post hematopoietic stem cell transplant ${ }^{130}$.

\section{Identification of T Cells Involved in GVHD Through TCRBV Analysis}

In graft-versus-host disease (GVHD), the donor $T$ cells recognize the host (recipient) MHC molecule as foreign, causing destruction of the cells expressing the allo-reactive molecule. Such reactions are also important in the recipient's defense against reactivation of latent infections such as CMV. Since it is the variable region of the TCR that is in intimate contact with the MHC molecule, determining what specific 
variable families of T cells can be linked to the destructive effects of GVHD has been a focus of investigation ${ }^{131-143}$. Due to the prior lack of standardized nomenclature for TCR gene families, classification of the variable region data has become complicated because different investigators named the same family different names and, conversely, different families were named the same. To resolve this classification dilema an international team was formed to assign consistent and systematic names to all of the TCR variable gene segments. Bernhard Arden published the results in $1995{ }^{144}$. At present, there are 32 functional alpha TCR variable families in humans with 69 subfamily members and 25 functional beta TCR variable families in humans with 91 subfamily members. As antibodies recognizing all of these TCR variable families are not available, an alternative approach is to use RT-PCR to evaluate the expression of the messages (mRNA) used to make these surface proteins. Primer panels previously designed to detect the wide range of TCR variable families do not, however, detect all of the TCR variable families outlined in the Arden paper ${ }^{138,145-189}$, due to the unavailability of the classification system at the time of primer development or the labor-intensive task of developing and validating a truly complete primer panel.

\section{Summary}

Since its early inception, bone marrow transplantation has been used to treat conditions ranging from exposure to a radiation accident in the late 1950s to treating conditions such as leukemia and lymphoma, aplastic anemia, as well as immunedeficiency disorders such as congenital neutropenia in the twenty first century ${ }^{6}$.

Despite advancements in the field of hematopoietic stem cell transplantation, serious complications can still occur post transplant. These include the occurrence of GVHD, severely immune-suppressed states that can lead to reactivation of latent infections such as CMV, and therapeutic agent toxicities ${ }^{13,130,190}$.

If it is possible to determine prior to transplant the GVHD-causing $T$ cells, those cells can be depleted or inhibited prior to blood or marrow infusion, thereby preventing the development of GVHD. Experiments performed in mice have demonstrated that when TCR variable families have been identified as being implicated in GVHD, those cells can be depleted prior to transplant, preventing development of a graft-versus-host reaction ${ }^{191}$. In addition, those cells can be adoptively transferred into a lethally 
irradiated host and initiate a graft-versus-host disease reaction ${ }^{192}$. Should trials in humans yield such predictable results, blood and marrow transplantation could become a treatment modality with a much-decreased risk of morbidity and mortality and offer hope of a cure to more patients.

\section{Research Objectives}

The main objective of the work presented in this dissertation is to understand the role of specific groups of $\mathrm{T}$ cells after hematopoietic stem cell transplantation in humans. The importance of $T$ cells post hematopoietic stem cell transplantation has long been recognized. There is a significant lack of understanding, though, as to the role specific $T$ cells play in this setting. This project will determine the role of specific $T$ cells, as identified by expression of their $\mathrm{T}$ cell receptor beta variable region, in certain post hematopoietic stem cell transplant events. This dissertation will detail the following objectives:

1. Develop a methodology to accurately detect expression of all the human TCRBV families. Many previous investigations have detailed molecular based methods used to identify the various TCRBV families in humans. These reports fail to account for the standardized classification of the TCRBV genes by the World Health Organization and often leave specific subfamilies and alleles undetected. Serological methods, such as antibody staining, have also been employed by prior studies. This method, too, lacks the ability to detect all of the human TCRBV genes. We aimed to develop a modern molecular based method that can specifically detect all alleles of the human TCRBV repertoire.

2. Utilizing technology developed in objective 1 , determine the association of specific $T$ cell with the following post hematopoietic stem cell transplant related events: 


\section{a. Graft-Versus-Host Disease (GVHD)}

GVHD is a common post hematopoietic stem cell transplantation complication and we aim to determine if specific families of $T$ cells are associated with the occurrence of this condition.

b. Cytomegalovirus (CMV) reactivation

During the immune suppressed state post transplant, patients often experience reactivation of latent infections, such as CMV, which contribute additional complications to the recovery stage. GVHD and CMV have been linked to each other in previous reports. We aim to determine (1) what specific families of $T$ cells are associated with reactivation of CMV post transplant and (2) if there is any overlap in the T cells associated with both GVHD and CMV.

c. Immunosuppressive therapies Cyclosporin A (CSA) and tacrolimus (FK506) Immunosuppressive therapies, such as CSA and FK506, are administered post hematopoietic stem cell transplant to curtail the development of graft rejection and graft-versus-host disease. These agents target activated $\mathrm{T}$ cells through their suppression of IL-2 production. We aim to determine if the effects of these agents on the TCRBV repertoire is the same with both CSA and FK506.

d. Correlation of engraftment profiles to baseline donor and recipient samples It is not known whether the identity of the engrafting TCRBV repertoire is more like that found in the recipient prior to transplant or if it mimics that found in the donor. We aim to determine the answer to this question. 


\section{REFERENCE LIST}

(1) THOMAS ED, Blume KG. Historical markers in the development of allogeneic hematopoietic cell transplantation. Biol Blood Marrow Transplant. 1999;5:341346.

(2) LORENZ E, UPHOFF D, REID TR, SHELTON E. Modification of irradiation injury in mice and guinea pigs by bone marrow injections. J Natl Cancer Inst. 1951;12:197-201.

(3) BARNES DW, CORP MJ, LOUTIT JF, NEAL FE. Treatment of murine leukaemia with $X$ rays and homologous bone marrow; preliminary communication. Br Med J. 1956;32:626-627.

(4) KURNICK NB, MONTANO A, GERDES JC, FEDER BH. Preliminary observations on the treatment of postirradiation hematopoietic depression in man by the infusion of stored autogenous bone marrow. Ann Intern Med. 1958;49:973-986.

(5) THOMAS ED, LOCHTE HL, Jr., LU WC, FERREBEE JW. Intravenous infusion of bone marrow in patients receiving radiation and chemotherapy. $\mathrm{N}$ Engl J Med. 1957;257:491-496.

(6) Mathe G, JAMMET $H$, PENDIC $B$ et al. [Transfusions and grafts of homologous bone marrow in humans after accidental high dosage irradiation.]. Rev Fr Etud Clin Biol. 1959;4:226-238.

(7) Mathe G, Amiel JL, Schwarzenberg L, Cattan A, Schneider M. Adoptive immunotherapy of acute leukemia: experimental and clinical results. Cancer Res. 1965;25:1525-1531.

(8) Clinical Bone Marrow and Blood Stem Cell Transplantation. second ed. New York: Cambridge University Press; 2000. 
(9) Russell NH, Hunter A, Rogers S, Hanley J, Anderson D. Peripheral blood stem cells as an alternative to marrow for allogeneic transplantation. Lancet. 1993;341:1482.

(10) Dreger P, Haferlach T, Eckstein V et al. G-CSF-mobilized peripheral blood progenitor cells for allogeneic transplantation: safety, kinetics of mobilization, and composition of the graft. Br J Haematol. 1994;87:609-613.

(11) Schwinger W, Mache C, Urban C, Beaufort F, Toglhofer W. Single dose of filgrastim (rhG-CSF) increases the number of hematopoietic progenitors in the peripheral blood of adult volunteers. Bone Marrow Transplant. 1993;11:489492.

(12) Weaver $\mathrm{CH}$, Buckner $\mathrm{CD}$, Longin $\mathrm{K}$ et al. Syngeneic transplantation with peripheral blood mononuclear cells collected after the administration of recombinant human granulocyte colony-stimulating factor. Blood. 1993;82:1981-1984.

(13) Bensinger WI, Storb R. Allogeneic peripheral blood stem cell transplantation. Rev Clin Exp Hematol. 2001;5:67-86.

(14) Szilvassy SJ, Humphries RK, Lansdorp PM, Eaves AC, Eaves CJ. Quantitative assay for totipotent reconstituting hematopoietic stem cells by a competitive repopulation strategy. Proc Natl Acad Sci U S A. 1990;87:87368740.

(15) Rice A, Reiffers J. Mobilized blood stem cells: immunophenotyping and functional characteristics. J Hematother. 1992;1:19-26.

(16) Torrelo A, Madero L, Mediero IG, Zambrano A. A cutaneous eruption from GCSF in a healthy donor. Pediatr Dermatol. 2000;17:205-207.

(17) Anderlini P, Przepiorka D, Champlin R, Korbling M. Biologic and clinical effects of granulocyte colony-stimulating factor in normal individuals. Blood. 1996;88:2819-2825. 
(18) Bensinger WI, Buckner CD, Shannon-Dorcy $\mathrm{K}$ et al. Transplantation of allogeneic CD34+ peripheral blood stem cells in patients with advanced hematologic malignancy. Blood. 1996;88:4132-4138.

(19) Sheridan WP, Begley CG, Juttner CA et al. Effect of peripheral-blood progenitor cells mobilised by filgrastim (G-CSF) on platelet recovery after high-dose chemotherapy. Lancet. 1992;339:640-644.

(20) Bensinger WI, Clift R, Martin P et al. Allogeneic peripheral blood stem cell transplantation in patients with advanced hematologic malignancies: a retrospective comparison with marrow transplantation. Blood. 1996;88:27942800.

(21) Przepiorka D, Ippoliti C, Khouri I et al. Allogeneic transplantation for advanced leukemia: improved short-term outcome with blood stem cell grafts and tacrolimus. Transplantation. 1996;62:1806-1810.

(22) Russell JA, Brown C, Bowen $T$ et al. Allogeneic blood cell transplants for haematological malignancy: preliminary comparison of outcomes with bone marrow transplantation. Bone Marrow Transplant. 1996;17:703-708.

(23) Azevedo WM, Aranha FJ, Gouvea JV et al. Allogeneic transplantation with blood stem cells mobilized by rhG-CSF for hematological malignancies. Bone Marrow Transplant. 1995;16:647-653.

(24) Barker JN, Davies SM, DeFor $T$ et al. Survival after transplantation of unrelated donor umbilical cord blood is comparable to that of human leukocyte antigen-matched unrelated donor bone marrow: results of a matched-pair analysis. Blood. 2001;97:2957-2961.

(25) Cohen Y, Nagler A. Cord blood biology and transplantation. Isr Med Assoc J. 2004;6:39-46. 
(26) Frassoni F, Podesta M, Maccario R et al. Cord blood transplantation provides better reconstitution of hematopoietic reservoir compared with bone marrow transplantation. Blood. 2003;102:1138-1141.

(27) Inoue $\mathrm{H}$, Yasuda $\mathrm{Y}$, Hattori $\mathrm{K}$ et al. The kinetics of immune reconstitution after cord blood transplantation and selected CD34+ stem cell transplantation in children: comparison with bone marrow transplantation. Int $\mathrm{J}$ Hematol. 2003;77:399-407.

(28) Keever CA, Abu-Hajir M, Graf W et al. Characterization of the alloreactivity and anti-leukemia reactivity of cord blood mononuclear cells. Bone Marrow Transplant. 1995;15:407-419.

(29) Rocha V, Cornish J, Sievers EL et al. Comparison of outcomes of unrelated bone marrow and umbilical cord blood transplants in children with acute leukemia. Blood. 2001;97:2962-2971.

(30) Laughlin MJ, Eapen M, Rubinstein P et al. Outcomes After Transplantation of Cord Blood or Bone Marrow From Unrelated Donors in Adults With Leukemia. Obstet Gynecol Surv. 2005;60:295-296.

(31) van Bekkum DW. Conditioning regimens for marrow grafting. Semin Hematol. 1984;21:81-90.

(32) Thomas E, Storb R, Clift RA et al. Bone-marrow transplantation (first of two parts). N Engl J Med. 1975;292:832-843.

(33) Atkinson K, Hansen JA, Storb R et al. T-cell subpopulations identified by monoclonal antibodies after human marrow transplantation. I. Helper-inducer and cytotoxic-suppressor subsets. Blood. 1982;59:1292-1298.

(34) Atkinson K. Reconstruction of the haemopoietic and immune systems after marrow transplantation. Bone Marrow Transplant. 1990;5:209-226. 
(35) Fujimaki K, Maruta A, Yoshida $\mathrm{M}$ et al. Immune reconstitution assessed during five years after allogeneic bone marrow transplantation. Bone Marrow Transplant. 2001;27:1275-1281.

(36) Morecki S, Gelfand $\mathrm{Y}$, Nagler A et al. Immune reconstitution following allogeneic stem cell transplantation in recipients conditioned by low intensity vs myeloablative regimen. Bone Marrow Transplant. 2001;28:243-249.

(37) Storek J, Witherspoon RP, Storb R. T cell reconstitution after bone marrow transplantation into adult patients does not resemble $\mathrm{T}$ cell development in early life. Bone Marrow Transplant. 1995;16:413-425.

(38) Gorer PA. The antigenic basis of tumor transplantation. J Pathol Bacteriol. 1938;47:231.

(39) Snell GD. Methods for the study of histocompatibility genes. J Genetics. 1948;49:87.

(40) Festenstein H, Demant P. HLA and H-2 basic immunogenetics, biology, and clinical relevance. In: Turk J, ed. Current Topics in Immunology. London: Edward Arnold; 1978:212.

(41) Deeg HJ, Yamaguchi M. Acute graft-versus-host disease. In: Atkinson K, ed. Clinical Bone Marrow and Blood Stem Cell Transplantation. New York: Cambridge University Press; 2000:681-699.

(42) Trowsdale J, Campbell RD. Complexity in the major histocompatibility complex. Eur J Immunogenet. 1992;19:45-55.

(43) Bodmer JG, Marsh SG, Albert ED et al. Nomenclature for factors of the HLA system, 1996. Tissue Antigens. 1997;49:297-321.

(44) Barnardo MC, Davey NJ, Bunce $M$ et al. A correlation between HLA-C matching and donor antirecipient CTL precursor frequency in bone marrow transplantation. Transplantation. 1996;61:1420-1423. 
(45) Petersdorf EW, Longton GM, Anasetti C et al. Association of HLA-C disparity with graft failure after marrow transplantation from unrelated donors. Blood. 1997;89:1818-1823.

(46) Tatari Z, Esperou H, Chastang C, and et al. Influence of donor/recipient HLA$C$ disparity in 110 unrelated bone marrow transplantation [abstract]. Human Immunology. 1996;47:80.

(47) Petersdorf EW, Longton GM, Anasetti $C$ et al. The significance of HLA-DRB1 matching on clinical outcome after HLA-A, B, DR identical unrelated donor marrow transplantation. Blood. 1995;86:1606-1613.

(48) Petersdorf EW, Longton GM, Anasetti $C$ et al. Definition of HLA-DQ as a transplantation antigen. Proc Natl Acad Sci U S A. 1996;93:15358-15363.

(49) Petersdorf EW, Smith AG, Mickelson EM et al. The role of HLA-DPB1 disparity in the development of acute graft-versus-host disease following unrelated donor marrow transplantation. Blood. 1993;81:1923-1932.

(50) Kronenberg M, Siu G, Hood LE, Shastri N. The molecular genetics of the Tcell antigen receptor and T-cell antigen recognition. Annu Rev Immunol. 1986;4:529-591.

(51) Petrie HT. Role of thymic organ structure and stromal composition in steadystate postnatal T-cell production. Immunol Rev. 2002;189:8-19.

(52) von Boehmer H, Aifantis I, Gounari F et al. Thymic selection revisited: how essential is it? Immunol Rev. 2003;191:62-78.

(53) Parham P, Ohta T. Population biology of antigen presentation by MHC class I molecules. Science. 1996;272:67-74.

(54) Arstila TP, Casrouge A, Baron $V$ et al. A direct estimate of the human alphabeta T cell receptor diversity. Science. 1999;286:958-961. 
(55) Medawar PB. The immunology of transplantation. Harvey Lecture Series. 1958;52:144.

(56) van Bekkum DW, de Vries MJ, van der WD. Lesions characteristic of secondary disease in germfree heterologous radiation chimeras. J Natl Cancer Inst. 1967;38:223-231.

(57) Billingham RE, Brent L. Quantitative studies on tissue transplantation immunity. IV. Induction of tolerance in newborn mice and studies on the phenomenon of runt disease. Philos Trans R Soc Lond B Biol Sci. 1959;242:477.

(58) BILLINGHAM RE, BRENT L. A simple method for inducing tolerance of skin homografts in mice. Transplant Bull. 1957;4:67-71.

(59) GOWANS JL. The fate of parental strain small lymphocytes in F1 hybrid rats. Ann N Y Acad Sci. 1962;99:432-455.

(60) Korngold R, Sprent J. T cell subsets and graft-versus-host disease. Transplantation. 1987;44:335-339.

(61) Alyea EP, Canning C, Neuberg D et al. CD8+ cell depletion of donor lymphocyte infusions using cd8 monoclonal antibody-coated high-density microparticles (CD8-HDM) after allogeneic hematopoietic stem cell transplantation: a pilot study. Bone Marrow Transplant. 2004;34:123-128.

(62) Cavazzana-Calvo M, Andre-Schmutz I, Hacein-Bey-Abina S et al. Improving immune reconstitution while preventing graft-versus-host disease in allogeneic stem cell transplantation. Semin Hematol. 2002;39:32-40.

(63) Chakraverty R, Robinson S, Peggs $\mathrm{K}$ et al. Excessive $\mathrm{T}$ cell depletion of peripheral blood stem cells has an adverse effect upon outcome following allogeneic stem cell transplantation. Bone Marrow Transplant. 2001;28:827834. 
(64) Drobyski WR. Evolving strategies to address adverse transplant outcomes associated with T cell depletion. J Hematother Stem Cell Res. 2000;9:327337.

(65) Henslee-Downey PJ, Parrish RS, MacDonald JS et al. Combined in vitro and in vivo $\mathrm{T}$ lymphocyte depletion for the control of graft-versus-host disease following haploidentical marrow transplant. Transplantation. 1996;61:738-745.

(66) Ho VT, Kim HT, Li S et al. Partial CD8+ T-cell depletion of allogeneic peripheral blood stem cell transplantation is insufficient to prevent graftversus-host disease. Bone Marrow Transplant. 2004;34:987-994.

(67) Kernan NA, Bordignon C, Keever CA et al. Graft failures after T cell depleted marrow transplants for leukemia: clinical and in vitro characteristics. Transplant Proc. 1987;19:29-32.

(68) Lee C, Brouillette M, Lamb L et al. Use of a closed system for V alpha betapositive $\mathrm{T}$ cell depletion of marrow for use in partially mismatched related donor (PMRD) transplantation. Prog Clin Biol Res. 1994;389:523-532.

(69) Lee SJ, Zahrieh D, Alyea EP et al. Comparison of T-cell-depleted and non-Tcell-depleted unrelated donor transplantation for hematologic diseases: clinical outcomes, quality of life, and costs. Blood. 2002;100:2697-2702.

(70) Lewin SR, Heller G, Zhang L et al. Direct evidence for new T-cell generation by patients after either T-cell-depleted or unmodified allogeneic hematopoietic stem cell transplantations. Blood. 2002;100:2235-2242.

(71) Marks DI, Bird JM, Vettenranta K et al. T cell-depleted unrelated donor bone marrow transplantation for acute myeloid leukemia. Biol Blood Marrow Transplant. 2000;6:646-653.

(72) Martin PJ, Hansen JA, Buckner CD et al. Effects of in vitro depletion of T cells in HLA-identical allogeneic marrow grafts. Blood. 1985;66:664-672. 
(73) Martin PJ, Rowley SD, Anasetti C et al. A phase I-II clinical trial to evaluate removal of CD4 cells and partial depletion of CD8 cells from donor marrow for HLA-mismatched unrelated recipients. Blood. 1999;94:2192-2199.

(74) Martino R, Martin-Henao G, Sureda A et al. Allogeneic peripheral blood stem cell transplantation with CD34+-cell selection and delayed T-cell add-back in adults. Results of a single center pilot study. Haematologica. 2000;85:11651171.

(75) Mavroudis DA, Dermime S, Molldrem J et al. Specific depletion of alloreactive T cells in HLA-identical siblings: a method for separating graft-versus-host and graft-versus-leukaemia reactions. Br J Haematol. 1998;101:565-570.

(76) Panigrahi S, Morecki S, Yacovlev E et al. A novel approach for prevention of lethal GVHD by selective elimination of alloreactive donor lymphocytes prior to stem cell transplantation. Exp Hematol. 2004;32:756-764.

(77) Rencher SD, Houston JA, Lockey TD, Hurwitz JL. Eliminating graft-versushost potential from $\mathrm{T}$ cell immunotherapeutic populations. Bone Marrow Transplant. 1996;18:415-420.

(78) Simpson D. T-cell depleting antibodies: new hope for induction of allograft tolerance in bone marrow transplantation? BioDrugs. 2003;17:147-154.

(79) Solomon SR, Mielke S, Savani BN et al. Selective depletion of alloreactive donor lymphocytes- a novel method to reduce the severity of graft-versushost disease in older patients undergoing matched sibling donor stem cell transplantation. Blood. 2005.

(80) Kernan NA, Collins NH, Juliano $L$ et al. Clonable $\mathrm{T}$ lymphocytes in $\mathrm{T}$ celldepleted bone marrow transplants correlate with development of graft-v-host disease. Blood. 1986;68:770-773.

(81) Kernan NA, Flomenberg N, Dupont B, O'Reilly RJ. Graft rejection in recipients of T-cell-depleted HLA-nonidentical marrow transplants for leukemia. 
Identification of host-derived antidonor allocytotoxic $T$ lymphocytes. Transplantation. 1987;43:842-847.

(82) Kirk AD. Immunosuppression without immunosuppression? How to be a tolerant individual in a dangerous world. Transplant Infectious Disease. 1999;1:65-75.

(83) Power M, Rosenbloom AJ. Immunological Aspects of Transplant Management: Pharmacotherapy and Rejection. Journal of Intensive Care Medicine. 2000;15:126.

(84) Vincenti F. What's in the pipeline? New immunosuppressive drugs in transplantation. Am J Transplant. 2002;2:898-903.

(85) Krensky AM, Weiss A, Crabtree G, Davis MM, Parham P. T-lymphocyteantigen interactions in transplant rejection. N Engl J Med. 1990;322:510-517.

(86) Hess AD, Fischer AC. Immune mechanisms in cyclosporine-induced syngeneic graft-versus-host disease. Transplantation. 1989;48:895-900.

(87) Roopenian D, Choi EY, Brown A. The immunogenomics of minor histocompatibility antigens. Immunol Rev. 2002;190:86-94.

(88) Fleischhauer K, Kernan NA, O'Reilly RJ, Dupont B, Yang SY. Bone marrowallograft rejection by $T$ lymphocytes recognizing a single amino acid difference in HLA-B44. N Engl J Med. 1990;323:1818-1822.

(89) Schreuder GM, Pool J, Blokland E et al. A genetic analysis of human minor histocompatibility antigens demonstrates Mendelian segregation independent of HLA. Immunogenetics. 1993;38:98-105.

(90) Marijt WA, Kernan NA, Diaz-Barrientos $T$ et al. Multiple minor histocompatibility antigen-specific cytotoxic $T$ lymphocyte clones can be generated during graft rejection after HLA-identical bone marrow transplantation. Bone Marrow Transplant. 1995;16:125-132. 
(91) de Bueger M, Bakker A, van Rood JJ, Van der WF, Goulmy E. Tissue distribution of human minor histocompatibility antigens. Ubiquitous versus restricted tissue distribution indicates heterogeneity among human cytotoxic $\mathrm{T}$ lymphocyte-defined non-MHC antigens. J Immunol. 1992;149:1788-1794.

(92) Friedman TM, Gilbert M, Briggs C, Korngold R. Repertoire analysis of CD8+ T cell responses to minor histocompatibility antigens involved in graft-versushost disease. J Immunol. 1998;161:41-48.

(93) van der HD, Goulmy E, Falkenburg JH et al. Recognition of minor histocompatibility antigens on lymphocytic and myeloid leukemic cells by cytotoxic T-cell clones. Blood. 1994;83:1060-1066.

(94) Warren EH, Greenberg PD, Riddell SR. Cytotoxic T-lymphocyte-defined human minor histocompatibility antigens with a restricted tissue distribution. Blood. 1998;91:2197-2207.

(95) Goulmy E, Gratama JW, Blokland E, Zwaan FE, van Rood JJ. A minor transplantation antigen detected by MHC-restricted cytotoxic $\mathrm{T}$ lymphocytes during graft-versus-host disease. Nature. 1983;302:159-161.

(96) Irle C, Beatty PG, Mickelson E, THOMAS ED, Hansen JA. Alloreactive T cell responses between HLA-identical siblings. Detection of anti-minor histocompatibility T cell clones induced in vivo. Transplantation. 1985;40:329333.

(97) Clift RA, Buckner CD, Appelbaum FR et al. Allogeneic marrow transplantation in patients with acute myeloid leukemia in first remission: a randomized trial of two irradiation regimens. Blood. 1990;76:1867-1871.

(98) Gale RP, Bortin MM, van Bekkum DW et al. Risk factors for acute graftversus-host disease. $\mathrm{Br} \mathrm{J}$ Haematol. 1987;67:397-406. 
(99) Hill GR, Crawford JM, Cooke KR et al. Total body irradiation and acute graftversus-host disease: the role of gastrointestinal damage and inflammatory cytokines. Blood. 1997;90:3204-3213.

(100) Ringden O. Viral infections and graft-vs.host disease. In: Burakoff SJ, Deeg HJ, Ferrara J, Atkinson K, eds. Graft-vs.-Host Disease. New York: Marcel Dekker, Inc.; 1990:467.

(101) Troutt AB, Kelso A. Enumeration of lymphokine mRNA-containing cells in vivo in a murine graft-versus-host reaction using the PCR. Proc Natl Acad Sci U S A. 1992;89:5276-5280.

(102) Velardi A, Varese P, Terenzi A et al. Lymphokine production by T-cell clones after human bone marrow transplantation. Blood. 1989;74:1665-1672.

(103) Xun CQ, Thompson JS, Jennings CD, Brown SA, Widmer MB. Effect of total body irradiation, busulfan-cyclophosphamide, or cyclophosphamide conditioning on inflammatory cytokine release and development of acute and chronic graft-versus-host disease in $\mathrm{H}$-2-incompatible transplanted SCID mice. Blood. 1994;83:2360-2367.

(104) Parkman R, Lenarsky C, Barrantes B, et al. Cytokines versus cytotoxic T lymphocytes (CTL) in the pathogenesis of acute graft-versus-host disease (GVHD). J Cellular Biochem. 1992;16a (Supp):186.

(105) Herve P, Flesch M, Tiberghien P et al. Phase I-II trial of a monoclonal antitumor necrosis factor alpha antibody for the treatment of refractory severe acute graft-versus-host disease. Blood. 1992;79:3362-3368.

(106) Holler E, Kolb HJ, Moller A et al. Increased serum levels of tumor necrosis factor alpha precede major complications of bone marrow transplantation. Blood. 1990;75:1011-1016.

(107) Holler E, Kolb HJ, Hintermeier-Knabe R et al. Role of tumor necrosis factor alpha in acute graft-versus-host disease and complications following 
allogeneic bone marrow transplantation. Transplant Proc. 1993;25:12341236.

(108) Huber C, Niederwieser D. Role of cytokines and major histocompatibility complex antigens in graft-versus-host disease: in vitro studies using T-cell lines and keratinocytes or hemopoietic targets. Haematol Blood Transfus. 1990;33:652-654.

(109) Mason DW, Dallman M, Barclay AN. Graft-versus-host disease induces expression of la antigen in rat epidermal cells and gut epithelium. Nature. 1981;293:150-151.

(110) McCarthy PL, Jr., Abhyankar S, Neben S et al. Inhibition of interleukin-1 by an interleukin-1 receptor antagonist prevents graft-versus-host disease. Blood. 1991;78:1915-1918.

(111) Mowat AM. Antibodies to IFN-gamma prevent immunologically mediated intestinal damage in murine graft-versus-host reaction. Immunology. 1989;68:18-23.

(112) Piguet PF, Grau GE, Allet B, Vassalli P. Tumor necrosis factor/cachectin is an effector of skin and gut lesions of the acute phase of graft-vs.-host disease. J Exp Med. 1987;166:1280-1289.

(113) Gifford GE, Lohmann-Matthes ML. Gamma interferon priming of mouse and human macrophages for induction of tumor necrosis factor production by bacterial lipopolysaccharide. J Natl Cancer Inst. 1987;78:121-124.

(114) Cooke KR, Gerbitz A, Crawford JM et al. LPS antagonism reduces graftversus-host disease and preserves graft-versus-leukemia activity after experimental bone marrow transplantation. J Clin Invest. 2001;107:15811589. 
(115) Jones JM, Wilson R, Bealmear PM. Mortality and gross pathology of secondary disease in germfree mouse radiation chimeras. Radiat Res. 1971;45:577-588.

(116) van Bekkum DW, Roodenburg J, Heidt PJ, van der WD. Mitigation of secondary disease of allogeneic mouse radiation chimeras by modification of the intestinal microflora. J Natl Cancer Inst. 1974;52:401-404.

(117) Ghayur T, Seemayer T, Lapp WS. Histological correlates of immune functional deficits in graft-versus-host disease. In: Burakoff SJ, Deeg HJ, Ferrara J, Atkinson K, eds. Graft-versus-Host Disease: Immunology, Pathophysiology, and Treatment. New York: Marcel Dekker, Inc.; 1990:109132.

(118) Elliott JF, Lin Y, Mizel SB et al. Induction of interleukin 2 messenger RNA inhibited by cyclosporin A. Science. 1984;226:1439-1441.

(119) Handschumacher RE, Harding MW, Rice J, Drugge RJ, Speicher DW. Cyclophilin: a specific cytosolic binding protein for cyclosporin A. Science. 1984;226:544-547.

(120) Harding MW, Handschumacher RE, Speicher DW. Isolation and amino acid sequence of cyclophilin. J Biol Chem. 1986;261:8547-8555.

(121) Harding MW, Galat A, Uehling DE, Schreiber SL. A receptor for the immunosuppressant FK506 is a cis-trans peptidyl-prolyl isomerase. Nature. 1989;341:758-760.

(122) Kronke M, Leonard WJ, Depper JM et al. Cyclosporin A inhibits T-cell growth factor gene expression at the level of mRNA transcription. Proc Natl Acad Sci U S A. 1984;81:5214-5218.

(123) Liu J, Farmer JD, Jr., Lane WS et al. Calcineurin is a common target of cyclophilin-cyclosporin A and FKBP-FK506 complexes. Cell. 1991;66:807815. 
(124) Maki N, Sekiguchi F, Nishimaki J et al. Complementary DNA encoding the human T-cell FK506-binding protein, a peptidylprolyl cis-trans isomerase distinct from cyclophilin. Proc Natl Acad Sci U S A. 1990;87:5440-5443.

(125) Metcalfe S. Cyclosporine does not prevent cytoplasmic calcium changes associated with lymphocyte activation. Transplantation. 1984;38:161-164.

(126) Randak C, Brabletz T, Hergenrother M, Sobotta I, Serfling E. Cyclosporin A suppresses the expression of the interleukin 2 gene by inhibiting the binding of lymphocyte-specific factors to the IL-2 enhancer. EMBO J. 1990;9:25292536.

(127) Siekierka JJ, Hung SH, Poe M, Lin CS, Sigal NH. A cytosolic binding protein for the immunosuppressant FK506 has peptidyl-prolyl isomerase activity but is distinct from cyclophilin. Nature. 1989;341:755-757.

(128) Standaert RF, Galat A, Verdine GL, Schreiber SL. Molecular cloning and overexpression of the human FK506-binding protein FKBP. Nature. 1990;346:671-674.

(129) Johnston A, Gudjonsson JE, Sigmundsdottir H, Ludviksson BR, Valdimarsson $\mathrm{H}$. The anti-inflammatory action of methotrexate is not mediated by lymphocyte apoptosis, but by the suppression of activation and adhesion molecules. Clin Immunol. 2005;114:154-163.

(130) Wingard JR. Opportunistic infections after blood and marrow transplantation. Transplant Infectious Disease. 1999;1:3-20.

(131) Akatsuka Y, Cerveny C, Hansen JA. T cell receptor clonal diversity following allogeneic marrow grafting. Hum Immunol. 1996;48:125-134.

(132) Dietrich PY, Caignard A, Diu A et al. Analysis of T-cell receptor variability in transplanted patients with acute graft-versus-host disease. Blood. 1992;80:2419-2424. 
(133) Dietrich PY, Caignard A, Lim A et al. In vivo T-cell clonal amplification at time of acute graft-versus-host disease. Blood. 1994;84:2815-2820.

(134) Epperson DE, Margolis DA, McOlash L, Janczak T, Barrett AJ. In vitro T-cell receptor $\mathrm{V}$ beta repertoire analysis may identify which $\mathrm{T}$-cell $\mathrm{V}$ beta families mediate graft-versus-leukaemia and graft-versus-host responses after human leucocyte antigen-matched sibling stem cell transplantation. $\mathrm{Br} \mathrm{J}$ Haematol. 2001;114:57-62.

(135) Hirokawa M, Matsutani $T$, Saitoh $\mathrm{H}$ et al. Distinct TCRAV and TCRBV repertoire and CDR3 sequence of $\mathrm{T}$ lymphocytes clonally expanded in blood and GVHD lesions after human allogeneic bone marrow transplantation. Bone Marrow Transplant. 2002;30:915-923.

(136) Kubo K, Yamanaka K, Kiyoi $\mathrm{H}$ et al. Different T-cell receptor repertoires between lesions and peripheral blood in acute graft-versus-host disease after allogeneic bone marrow transplantation. Blood. 1996;87:3019-3026.

(137) Liu X, Chesnokova V, Forman SJ, Diamond DJ. Molecular analysis of T-cell receptor repertoire in bone marrow transplant recipients: evidence for oligoclonal T-cell expansion in graft-versus-host disease lesions. Blood. 1996;87:3032-3044.

(138) Margolis DA, Casper JT, Segura AD et al. Infiltrating T cells during liver graftversus-host disease show a restricted T-cell repertoire. Biol Blood Marrow Transplant. 2000;6:408-415.

(139) Michalek J, Collins RH, Durrani HP et al. Definitive separation of graft-versusleukemia- and graft-versus-host-specific CD4+ $T$ cells by virtue of their receptor beta loci sequences. Proc Natl Acad Sci U S A. 2003;100:11801184. 
(140) Nikaein A, Poole T, Fishbeck R et al. Characterization of skin-infiltrating cells during acute graft-versus-host disease following bone marrow transplantation using unrelated marrow donors. Hum Immunol. 1994;40:68-76.

(141) Tsutsumi $Y$, Tanaka J, Miura $Y$ et al. Molecular analysis of T-cell repertoire in patients with graft-versus-host disease after allogeneic stem cell transplantation. Leuk Lymphoma. 2004;45:481-488.

(142) Wang L, Tadokoro K, Tokunaga K et al. Restricted use of T-cell receptor V beta genes in posttransfusion graft-versus-host disease. Transfusion. 1997;37:1184-1191.

(143) Yamanaka K, Kwok WW, Mickelson EM et al. Selective T-cell-receptor gene usage in allorecognition and graft-versus-host disease. Transplantation. 1993;55:1167-1175.

(144) Arden B, Clark SP, Kabelitz D, Mak TW. Human T-cell receptor variable gene segment families. Immunogenetics. 1995;42:455-500.

(145) Abe J, Forrester J, Nakahara T et al. Selective stimulation of human T cells with streptococcal erythrogenic toxins A and B. J Immunol. 1991;146:37473750 .

(146) Abe J, Kotzin BL, Jujo K et al. Selective expansion of T cells expressing T-cell receptor variable regions $\mathrm{V}$ beta 2 and $\mathrm{V}$ beta 8 in Kawasaki disease. Proc Natl Acad Sci U S A. 1992;89:4066-4070.

(147) Ben Nun A, Liblau RS, Cohen L et al. Restricted T-cell receptor $V$ beta gene usage by myelin basic protein-specific T-cell clones in multiple sclerosis: predominant genes vary in individuals. Proc Natl Acad Sci U S A. 1991;88:2466-2470.

(148) Blumberg RS, Yockey CE, Gross GG, Ebert EC, Balk SP. Human intestinal intraepithelial lymphocytes are derived from a limited number of $\mathrm{T}$ cell clones 
that utilize multiple $\vee$ beta T cell receptor genes. J Immunol. 1993;150:51445153.

(149) Bragado R, Lauzurica P, Lopez D, Lopez de Castro JA. T cell receptor V beta gene usage in a human alloreactive response. Shared structural features among HLA-B27-specific T cell clones. J Exp Med. 1990;171:1189-1204.

(150) Choi YW, Kotzin B, Herron L et al. Interaction of Staphylococcus aureus toxin "superantigens" with human T cells. Proc Natl Acad Sci U S A. 1989;86:89418945.

(151) Dietrich PY, Caignard A, Diu A et al. Analysis of T-cell receptor variability in transplanted patients with acute graft-versus-host disease. Blood. 1992;80:2419-2424.

(152) Dietrich PY, Caignard A, Lim A et al. In vivo T-cell clonal amplification at time of acute graft-versus-host disease. Blood. 1994;84:2815-2820.

(153) Dombret H, Loiseau P, Bories JC, Sigaux F. Unexpected consistent involvement of $\mathrm{V}$ beta gene segments in inappropriate $\mathrm{T}$-cell receptor beta gene rearrangements occurring in B-lineage acute lymphoblastic leukemias. Blood. 1992;80:2614-2621.

(154) Even J, Lim A, Puisieux I et al. T-cell repertoires in healthy and diseased human tissues analysed by T-cell receptor beta-chain CDR3 size determination: evidence for oligoclonal expansions in tumours and inflammatory diseases. Res Immunol. 1995;146:65-80.

(155) Gagne K, Brouard S, Giral M et al. Highly altered V beta repertoire of T cells infiltrating long-term rejected kidney allografts. J Immunol. 2000;164:15531563.

(156) Genevee C, Diu A, Nierat J et al. An experimentally validated panel of subfamily-specific oligonucleotide primers ( $V$ alpha 1-w29/V beta 1-w24) for 
the study of human $\mathrm{T}$ cell receptor variable $\mathrm{V}$ gene segment usage by polymerase chain reaction. Eur J Immunol. 1992;22:1261-1269.

(157) Gorochov G, Debre P, Leblond V et al. Oligoclonal expansion of CD8+ CD57+ T cells with restricted T-cell receptor beta chain variability after bone marrow transplantation. Blood. 1994;83:587-595.

(158) Gorski J, Yassai $M$, Zhu $X$ et al. Circulating $T$ cell repertoire complexity in normal individuals and bone marrow recipients analyzed by CDR3 size spectratyping. Correlation with immune status. J Immunol. 1994;152:51095119.

(159) Hirokawa M, Matsutani $T$, Horiuchi $T$ et al. Extensive clonal expansion of $T$ lymphocytes causes contracted diversity of complementarity-determining region 3 and skewed T cell receptor repertoires after allogeneic hematopoietic cell transplantation. Bone Marrow Transplant. 2001;27:607-614.

(160) Hirokawa M, Matsutani T, Saitoh $\mathrm{H}$ et al. Distinct TCRAV and TCRBV repertoire and CDR3 sequence of $\mathrm{T}$ lymphocytes clonally expanded in blood and GVHD lesions after human allogeneic bone marrow transplantation. Bone Marrow Transplant. 2002;30:915-923.

(161) Ikeda $H$, Sato N, Matsuura A, Kikuchi K. Analysis of T-cell receptor V region gene usage of cytotoxic T-lymphocytes and tumor-infiltrating lymphocytes derived from human autologous gastric signet ring cell carcinomas. Cancer Res. 1993;53:3078-3084.

(162) Kalams SA, Johnson RP, Trocha AK et al. Longitudinal analysis of $\mathrm{T}$ cell receptor (TCR) gene usage by human immunodeficiency virus 1 envelopespecific cytotoxic T lymphocyte clones reveals a limited TCR repertoire. J Exp Med. 1994;179:1261-1271.

(163) Kalams SA, Johnson RP, Dynan MJ et al. T cell receptor usage and fine specificity of human immunodeficiency virus 1-specific cytotoxic T lymphocyte 
clones: analysis of quasispecies recognition reveals a dominant response directed against a minor in vivo variant. J Exp Med. 1996;183:1669-1679.

(164) Kubo H, Abe J, Obata F et al. Dual recognition of a human cytotoxic T-cell clone for melanoma antigens. Cancer Res. 1996;56:2368-2374.

(165) Kuijpers KC, van Dongen JJ, van der BP et al. A combined immunodeficiency with oligoclonal CD8+, $\mathrm{V}$ beta 3-expressing, cytotoxic $\mathrm{T}$ lymphocytes in the peripheral blood. J Immunol. 1992;149:3403-3410.

(166) Kusaka S, Grailer AP, Fechner JH, Jr. et al. Clonotype analysis of human alloreactive T cells: a novel approach to studying peripheral tolerance in a transplant recipient. J Immunol. 2000;164:2240-2247.

(167) Lang R, Pfeffer K, Wagner H, Heeg K. A rapid method for semiquantitative analysis of the human $\mathrm{V}$ beta-repertoire using TaqManR PCR. J Immunol Methods. 1997;203:181-192.

(168) Liu X, Chesnokova V, Forman SJ, Diamond DJ. Molecular analysis of T-cell receptor repertoire in bone marrow transplant recipients: evidence for oligoclonal T-cell expansion in graft-versus-host disease lesions. Blood. 1996;87:3032-3044.

(169) Lynas C, Howe D. Additional TCRV beta primers and minor method modifications improve detection of clonal T-cell populations by RT-PCR. Mol Pathol. 1997;50:53-55.

(170) Maslanka K, Piatek T, Gorski J, Yassai M, Gorski J. Molecular analysis of T cell repertoires. Spectratypes generated by multiplex polymerase chain reaction and evaluated by radioactivity or fluorescence. Hum Immunol. 1995;44:28-34.

(171) Matsutani T, Yoshioka T, Tsuruta Y, Iwagami S, Suzuki R. Analysis of TCRAV and TCRBV repertoires in healthy individuals by microplate hybridization assay. Hum Immunol. 1997;56:57-69. 
(172) Matsutani T, Yoshioka T, Tsuruta $Y$ et al. Restricted usage of T-cell receptor alpha-chain variable region (TCRAV) and T-cell receptor beta-chain variable region (TCRBV) repertoires after human allogeneic haematopoietic transplantation. Br J Haematol. 2000;109:759-769.

(173) McCarthy KP, Sloane JP, Kabarowski JH, Matutes E, Wiedemann LM. The rapid detection of clonal T-cell proliferations in patients with lymphoid disorders. Am J Pathol. 1991;138:821-828.

(174) Nuovo GJ, Morrison C, Porcu P, Caligiuri MA, Suster S. In situ determination of T-cell receptor beta expression patterns. J Histochem Cytochem. 2001;49:139-145.

(175) Oaks MK, Downs JA, Tector AJ. T-cell receptor alpha and beta chain gene expression in cells infiltrating human cardiac allografts. Am J Med Sci. 1995;309:26-34.

(176) Orsini E, Alyea EP, Schlossman R et al. Changes in T cell receptor repertoire associated with graft-versus-tumor effect and graft-versus-host disease in patients with relapsed multiple myeloma after donor lymphocyte infusion. Bone Marrow Transplant. 2000;25:623-632.

(177) Panzara MA, Gussoni E, Steinman L, Oksenberg JR. Analysis of the T cell repertoire using the PCR and specific oligonucleotide primers. Biotechniques. 1992;12:728-735.

(178) Pilch $\mathrm{H}$, Hohn $\mathrm{H}$, Freitag $\mathrm{K}$ et al. Improved assessment of T-cell receptor (TCR) VB repertoire in clinical specimens: combination of TCR-CDR3 spectratyping with flow cytometry-based TCR VB frequency analysis. Clin Diagn Lab Immunol. 2002;9:257-266.

(179) Puisieux I, Even J, Pannetier C et al. Oligoclonality of tumor-infiltrating lymphocytes from human melanomas. J Immunol. 1994;153:2807-2818. 
(180) Roers A, Montesinos-Rongen M, Hansmann ML, Rajewsky K, Kuppers R. Amplification of TCRbeta gene rearrangements from micromanipulated single cells: T cells rosetting around Hodgkin and Reed-Sternberg cells in Hodgkin's disease are polyclonal. Eur J Immunol. 1998;28:2424-2431.

(181) Sarzotti M, Patel DD, Li X et al. T cell repertoire development in humans with SCID after nonablative allogeneic marrow transplantation. J Immunol. 2003;170:2711-2718.

(182) Sebille F, Gagne K, Guillet M et al. Direct recognition of foreign MHC determinants by naive $T$ cells mobilizes specific Vbeta families without skewing of the complementarity-determining region 3 length distribution. $\mathrm{J}$ Immunol. 2001;167:3082-3088.

(183) Smith TJ, Terada N, Robinson CC, Gelfand EW. Acute infectious mononucleosis stimulates the selective expression/expansion of $\mathrm{V}$ beta 6.1-3 and $\mathrm{V}$ beta 7 T cells. Blood. 1993;81:1521-1526.

(184) Tsuruta Y, Yoshioka T, Suzuki R, Sakata T. Analysis of the population of human $\mathrm{T}$ cell receptor gamma and delta chain variable region subfamilies by reverse dot blot hybridization. J Immunol Methods. 1994;169:17-23.

(185) Tsutsumi Y, Tanaka J, Sugita J et al. Analysis of T-cell repertoire and mixed chimaerism in a patient with aplastic anaemia after allogeneic bone marrow transplantation. Br J Haematol. 2002;118:136-139.

(186) Ueda D, Sato N, Matsuura A et al. T-cell receptor gene structures of HLAA26-restricted cytotoxic $T$ lymphocyte lines against human autologous pancreatic adenocarcinoma. Jpn J Cancer Res. 1995;86:691-697.

(187) Willenbrock K, Roers A, Blohbaum B, Rajewsky K, Hansmann ML. CD8(+) T cells in Hodgkin's disease tumor tissue are a polyclonal population with limited clonal expansion but little evidence of selection by antigen. Am J Pathol. 2000;157:171-175. 
(188) Wucherpfennig KW, Ota K, Endo $\mathrm{N}$ et al. Shared human $\mathrm{T}$ cell receptor $\mathrm{V}$ beta usage to immunodominant regions of myelin basic protein. Science. 1990;248:1016-1019.

(189) Yoshioka T, Matsutani T, Iwagami S et al. Quantitative analysis of the usage of human $\mathrm{T}$ cell receptor alpha and beta chain variable regions by reverse dot blot hybridization. J Immunol Methods. 1997;201:145-155.

(190) O'Brien SN, Blijlevens NM, Mahfouz TH, Anaissie EJ. Infections in patients with hematological cancer: recent developments. Hematology (Am Soc Hematol Educ Program ). 2003;438-472.

(191) Muluk SC, Hakim FT, Shearer GM. Regulation of graft-versus-host-reaction by Mlsa-reactive donor T cells. Eur J Immunol. 1992;22:1967-1973.

(192) Friedman TM, Statton D, Jones SC et al. Vbeta spectratype analysis reveals heterogeneity of CD4+ T-cell responses to minor histocompatibility antigens involved in graft-versus-host disease: correlations with epithelial tissue infiltrate. Biol Blood Marrow Transplant. 2001;7:2-13. 
CHAPTER 2

AN IMPROVED METHODOLOGY TO DETERMINE HUMAN TCRBV GENE EXPRESSION 


\begin{abstract}
Comprehensive gene expression analysis of the $T$ cell receptor repertoire of an individual can be very useful in evaluating the immune response in a variety of conditions. Antibody based analysis methods can detect approximately sixty percent of the human $\mathrm{T}$ cell receptor beta variable (TCRBV) proteins, while gene expression analysis, primarily through employment of the polymerase chain reaction (PCR), has had somewhat greater success in the detection of additional TCRBV families. Many of these previous PCR methods, however, have been unable to detect all 91 alleles of the human TCRBV genes. This is primarily due to either deficiencies in the amplification of all of the variable beta families, subfamilies, and alleles, or the prior lack of a systematic classification of the TCR variable family gene segment sequences. We describe here a real time reverse-transcription polymerase chain reaction based method, which allows efficient automation and integration of amplification, detection, and analysis with sequence specific detection of all $T$ cell receptor beta variable gene families, subfamilies, and alleles. This method, which in itself contributes significant improvements over existing technologies through its comprehensiveness and efficiency, also functions independently of variables such as sample source and sample processing and has the ability to run on multiple real-time PCR platforms, affording one the implementation of personal preferences.
\end{abstract}

\title{
INTRODUCTION
}

T cells constitute a component of the immune system that is able to distinguish "self" versus "non-self". This is accomplished through the interaction of their $\mathrm{T}$ cell receptor (TCR) with the antigen:major histocompatibility complex (a:MHC) expressed on the surface of cells. The $\alpha \beta$ T cell receptor is a heterodimer, one component of which is a beta (B) chain, consisting of both a variable (V) and a constant $(C)$ region. It is the variable region of the chain that directly contacts the a:MHC, eliciting the $T$ cell response. Each individual has multiple TCRBV gene segments (or families) allowing for the ability to respond to a large number of a:MHC complexes ${ }^{1}$. 
A primary way to analyze the $T$ cell receptor repertoire in an individual is through the use of antibody-based methods. Antibody based analysis methods can detect approximately sixty percent of the human $T$ cell receptor beta variable (TCRBV) proteins, while gene expression analysis, primarily through employment of the polymerase chain reaction (PCR) ${ }^{2}$, has had somewhat greater success in the detection of additional TCRBV families. Many of these previous PCR methods, however, have been unable to detect all 91 alleles of the human TCRBV genes. Such a comprehensive PCR strategy, however, requires the usage of both uniform and systematic organizations of the TCRBV genetic sequences. Such a TCRBV classification system was established by the World Health Organization (WHO) and has resulted in the identification of 25 different functional B variable families (with 91 subfamily and allele members total) ${ }^{3}$. Based on the WHO classification of the TCRBV families, two sequences reside within the same family if there is at least $50 \%$ homology between the two sequences. Subfamily members share at least $75 \%$ sequence homology and alleles of a given TCRV gene differ at no more than a few residues ${ }^{3}$.

Previous attempts at establishing PCR-based methods to evaluate the expression of all members of the TCR families have not taken into account the new WHO systematic classification or the wide variety of subfamilies and alleles that exist for many of the variable families ${ }^{4-49}$. When possible, such references were consulted for potential primer sequences. However, many of those sequences did not satisfy the requirements of amplifying all of the various subfamilies and alleles within a given variable family or they inadvertently cross-amplified the sequence of a closely related variable family. The generation of a comprehensive panel of TCRBV primer sequences presented a significant challenge as the TCRBV families all share nearly $50 \%$ homology with each other and sequences designed to detect a specific family can inadvertently cross-amplify a closely related TCRBV family. We designed primers that will specifically detect all known alleles within the identified TCRBV families and, when possible, we designed a single primer to detect all alleles of a given TCRBV family, thereby improving on previous panels that required using multiple primer sequences to amplify multiple alleles of a given TCRBV family. In addition, some of the primer sequences from previous panels, while potentially meeting our stringent specificity requirements, 
had a melting temperature that fell outside of our desired ten-degree melting range of $55^{\circ} \mathrm{C}$ to $65^{\circ} \mathrm{C}$, making it difficult to analyze expression of all of the TCRBV families in a single experiment with a single amplification cycling protocol.

We describe here how we have established a complete panel of PCR primers that can be used with sequence specific real-time PCR methodology to evaluate the expression of all the TCRBV gene families, including all subfamily and allele members. The user has the flexibility of using many sample sources and processing methods, as well as benefiting from automated and integrated amplification, detection, and analysis in a gel free environment on a wide variety of real time PCR platforms. The technology can be applied to any area of study examining T cell biology, including autoimmunity, transplantation, cancer therapy, and infectious disease.

\section{MATERIALS AND METHODS}

\section{Primer and Probe Development}

Primer sequences were developed using the TCRBV classification system described by Arden, et al. ${ }^{3}$. Sequences were analyzed and potential primer sequences were evaluated for cross-reactivity using GenBank's BLAST tool (National Center for Biotechnology Information, http://www.ncbi.nlm.nih.gov/BLAST/). Human $18 \mathrm{~S}$ rRNA primers and $\operatorname{TaqMan}^{\circledR}$ probe were designed using Beacon Designer 2 software (PremierBiosoft International, Palo Alto, CA, USA). TaqMan ${ }^{\circledR}$ probes were analyzed for cross-reactivity using GenBank's BLAST tool (National Center for Biotechnology Information).

\section{Peripheral Blood Samples}

A volume of $\sim 20 \mathrm{~mL}$ of peripheral blood was collected, via venipuncture from individual healthy donors and from a hematopoietic stem cell transplant patient, into acid citrate dextrose VACUTAINER ${ }^{\mathrm{TM}}$ blood collection tubes (Becton Dickinson, Franklin Lakes, NJ, USA). Informed consent was obtained from participants after the nature and possible consequences of the study had been fully explained according to West Virginia University's Internal Review Board guidelines. Buffy coat layers were isolated via centrifugation at 3300 rcf for 10 minutes. Contaminating red blood cells were removed by hypotonic lysis. 


\section{Flow Cytometric Analysis}

Peripheral blood composition was determined by light scatter profiling using a CELL-DYN 3500 (Abbott Diagnostics, Santa Clara, CA, USA). Additional classification of the lymphocyte population was performed by cell surface staining using antibodies specific to CD4 (Beckman Coulter, New York, NY, USA), at a volume of $20 \mu \mathrm{L}$ antibody per $5 \times 10^{5}$ cells, CD8, and CD19 (Caltag Laboratories, Burlingame, CA, USA), both at antibody concentrations of $1 \mu \mathrm{g}$ per $1 \times 10^{6}$ cells. Cells were blocked prior to antibody addition by incubating cells for five minutes at room temperature with human IgG at a concentration of $200 \mu \mathrm{g}$ per $5 \times 10^{5}$ cells (Sigma Chemical Co., St. Louis, MO, USA). After antibody addition, cells were incubated 30 minutes in the dark at room temperature followed by a single wash with 1x PBS. The stained cells were then fixed in $500 \mu \mathrm{L}$ of $1 \%$ paraformaldehyde. All prepared samples were analyzed by flow cytometric analysis using a FACScan ${ }^{\mathrm{TM}}$ (Becton Dickinson), which had been calibrated using three color Calibrite ${ }^{\mathrm{TM}}$ Beads (Becton Dickinson) and FACSCOMP ${ }^{\mathrm{TM}}$ software (Becton Dickinson). For further lymphocyte analysis of $\mathrm{CD}_{19}{ }^{+}, \mathrm{CD}^{+}$, and $\mathrm{CD} 4^{+}$ expression 10,000 total events were collected for each sample. SSC and FSC data were acquired in the linear mode and the FL1, FL2, and FL3 parameters were collected logarithmically. Data analysis was performed using Windows Multiple Document Interface (WinMDI) version 2.8 (Joseph Trotter, The Scripps Research Institute, http://facs.scripps.edu/software.html).

\section{RNA Isolation}

Total RNA was isolated from 20-40 x $10^{6}$ white blood cells using TRIzol ${ }^{\circledR}$ Reagent according to the manufacturer's directions (Ambion, Austin, TX, USA). RNA was dissolved in ultra-PURE ${ }^{\mathrm{TM}}$ Distilled DNAse and RNAse free water (Invitrogen Corporation, Carlsbad, CA, USA). DNase treatment was performed on isolated RNA according to the manufacturer's recommendations using DNA-free ${ }^{\mathrm{TM}}$ (Ambion). RNA purity and concentration was determined by standard 260nm:280nm spectrophotometric analysis using a Genesis 10UV Spectronic Unicam (Spectronic Instruments, Rochester, NY, USA). 


\section{$R T-P C R$}

One Step RT-PCR was performed using the QuantiTect ${ }^{\mathrm{TM}}$ Probe RT-PCR kit (Qiagen, Valencia, CA, USA). Recommended reaction mixtures were scaled down to a total reaction volume of $20 \mu \mathrm{L}$ using $0.04 \mu \mathrm{g}$ RNA with the following primer and probe concentrations: $0.4 \mu \mathrm{M}$ TCRBV primer (Biosource International, Camarillo, CA, USA), $0.4 \mu \mathrm{M}$ TCRBC primer (Biosource International), and 0.2 $\mu \mathrm{M}$ TCRBC TaqMan ${ }^{\circledR}$ probe, 5' 6-FAM, 3' BHQ ${ }^{\mathrm{TM}}$-1 (Integrated DNA Technologies, Inc., Coralville, IA, USA). 18SrRNA control reactions were performed in parallel using $0.4 \mu \mathrm{M}$ each of sense and anti-sense primers (Biosource International) and $0.2 \mu \mathrm{M}$ 18SrRNA TaqMan ${ }^{\circledR}$ probe, 5' 6-FAM, 3' $\mathrm{BHQ}^{\mathrm{TM}}-1$ (Integrated DNA Technologies, Inc.).

An iCycler ${ }^{\mathrm{TM}}$ (BioRad Laboratories, Hercules, CA, USA) was used for the RT and amplification cycles. RT was performed at $50^{\circ} \mathrm{C}$ for 60 minutes, max ramp speed, followed by an initial Taq DNA polymerase activation step of 15 minutes at $95^{\circ} \mathrm{C}$, $\max$ ramp speed. A TouchDown PCR approach ${ }^{50}$ was used with the following cycling conditions: denaturation for 15 seconds at $95^{\circ} \mathrm{C}$, max ramp speed, annealing for 30 seconds starting at $70^{\circ} \mathrm{C}$ decreasing by $2^{\circ} \mathrm{C}$ for 10 repeats, max ramp speed, and extension for 40 seconds at $72^{\circ} \mathrm{C}$, min ramp speed. After this TouchDown of the annealing temperature, 50 cycles were performed as follows with the optical data collection occurring at the extension step: 15 seconds at $95^{\circ} \mathrm{C}$ (max ramp speed), 30 seconds at $52^{\circ} \mathrm{C}$ (max ramp speed), and 40 seconds at $60^{\circ} \mathrm{C}$ (min ramp speed). Reactions were held at $4^{\circ} \mathrm{C}$ upon the conclusion of the run. Amplification efficiencies using CDNA dilutions were determined using the above described cycling protocol with the deletion of the reverse transcription cycle of $50^{\circ} \mathrm{C}$ for 60 minutes.

\section{cDNA isolation}

PCR products were electrophoresed on a $2 \%$ agarose gel using $20 \mu \mathrm{L}$ PCR product and $4 \mu \mathrm{L}$ tri-color 6X loading dye (Promega, Madison, WI, USA). Promega PCR marker was loaded into a control lane at the manufacturer's specifications (Promega). Product bands were excised using the QIAquick ${ }^{\circledR}$ Gel Extraction Kit protocol according to the manufacturer's instructions (Qiagen). cDNA purity and concentration was determined by standard 260nm:280nm spectrophotometric analysis using a Genesis 
10UV Spectronic Unicam (Spectronic Instruments). cDNA dilutions were performed using ultra-PURE ${ }^{\mathrm{TM}}$ Distilled DNAse and RNAse free water (Invitrogen Corporation).

\section{Southern Blot Analysis}

Nucleic acid bands were transferred from the $2 \%$ agarose gel (described above) to BioBond ${ }^{\mathrm{TM}}$ Plus Nylon Membrane (Sigma Chemical Co.) using the Alkaline Southern Breeze $^{\text {TM }}$ Blotting Kit (Sigma Chemical Co.). The membrane was blocked overnight at room temperature using a blocking solution of 1X Saline-Sodium Citrate (SSC), 1\% Bovine Serum Albumin (BSA) (Fisher Scientific, Pittsburgh, PA, USA), and 1\% Sodium Dodecyl Sulfate (SDS) (Sigma Chemical Co.). A one hour incubation at room temperature was then performed using $20 \mathrm{pmol}$ biotinylated primary probe directed to the TCRBC region (Integrated DNA Technologies, Inc.) per $\mathrm{mL}$ blocking buffer followed by three five minute washings with a wash buffer of 1X SSC and 1\% SDS (Sigma Chemical Co.). A streptavidin-HRP conjugate (Amersham Biosciences, Piscataway, NJ, USA) was added at a 1:5000 dilution in blocking buffer for 1 hour at room temperature. Three final five-minute washes were performed using the wash buffer. The membrane was developed using $\mathrm{ECL}^{\mathrm{TM}}$ detection reagents (Amersham Biosciences) according to the manufacturer's instructions. The membrane was then exposed to Biomax ${ }^{\mathrm{TM}} \mathrm{MR}$ film (Eastman Kodak Company, Rochester, NY, USA). The film was developed using a 100 Plus Automatic X-Ray Film Processor (All-Pro Imaging, Hicksville, NY, USA).

\section{RESULTS}

\section{Primer Sequence Panel}

The final TCRBV primer panel consists of fewer than 30 primers and one TaqMan $^{\circledR}$ probe. The amplification of the various alleles and subfamily members for a given TCRBV family is diagrammed in Table I. As previously mentioned, each TCRBV family can have multiple subfamily members, some with additional alleles. As described by Arden, et al. ${ }^{3}$, we have adhered to the accepted classification and nomenclature for these families and their subfamily and allele members. 
Listed on the far left columns of Table 1 are the names of the primers and their respective TCRBV families, whose subfamily and allele members are listed in the adjacent column. A single primer was used for the amplification of a given TCRBV with the following exceptions: two primers were needed to amplify all BV6 (B6JLB2 and B6JLB3), BV12 (B12.1JLB and B12.2.3JLB), and BV13 (B13.1eJLB2 and B13.5JLB2) members. There is no primer to amplify BV10 or BV19 as these families only contain nonfunctional orphan or pseudogenes ${ }^{3}$. 


\begin{tabular}{|c|c|c|}
\hline $\begin{array}{c}\text { primer } \\
\text { name(s) }\end{array}$ & $\begin{array}{c}\text { TCR } \\
\text { family }\end{array}$ & $\begin{array}{c}\text { TCR } \\
\text { subfamily }\end{array}$ \\
\hline$\overline{\mathrm{B} 1 \mathrm{H}}$ & B variable 1 & BV1S1A1 \\
\hline & & BV1S1A2 \\
\hline$\overline{\text { B2Blum }}$ & B variable 2 & BV2S1A1 \\
\hline & & $\mathrm{BV} 2 \mathrm{~S} 1 \mathrm{~A} 2$ \\
\hline & & $\mathrm{BV} 2 \mathrm{~S} 1 \mathrm{~A} 3$ \\
\hline & & BV2S1A4 \\
\hline & & BV2S1A5 \\
\hline$\overline{\mathrm{B} 3 \mathrm{H}}$ & B variable 3 & BV3S1 \\
\hline $\mathrm{B} 4 \mathrm{H}$ & B variable 4 & BV4S1A1 \\
\hline & & BV4S1A2 \\
\hline & & BV4S1A3 \\
\hline$\overline{\mathrm{B} 5 \mathrm{JLB}}$ & B variable 5 & BV5S1A1 \\
\hline & & BV5S1A2 \\
\hline & & BV5S2 \\
\hline & & BV5S3A1 \\
\hline & & BV5S3A2 \\
\hline & & BV5S3A3 \\
\hline & & BV5S4A1 \\
\hline & & BV5S4A2 \\
\hline & & BV5S6A1 \\
\hline & & BV5S6A2 \\
\hline & & BV5S6A3 \\
\hline$\overline{\text { B6JLB2/B6JLB3 }}$ & B variable 6 & BV6S1A1 \\
\hline & & BV6S1A3 \\
\hline & & BV6S2A1 \\
\hline & & BV6S2A2 \\
\hline & & BV6S3A1 \\
\hline & & BV6S4A1 \\
\hline & & BV6S4A2 \\
\hline & & BV6S4A3 \\
\hline & & BV6S4A4 \\
\hline & & BV6S4A5 \\
\hline & & BV6S4A6 \\
\hline & & BV6S5A1 \\
\hline & & BV6S5A2 \\
\hline & & BV6S6A1 \\
\hline & & BV6S6A2 \\
\hline & & BV6S8A1 \\
\hline & & BV6S8A2 \\
\hline$\overline{B 7 J L B}$ & B variable 7 & BV7S1A1 \\
\hline & & BV7S2A1 \\
\hline & & BV7S2A2 \\
\hline & & BV7S3A1 \\
\hline & & BV7S3A2 \\
\hline$\overline{\mathrm{B} 8 \mathrm{JLB}}$ & B variable 8 & BV8S1 \\
\hline & & BV8S2A1 \\
\hline & & BV8S2A2 \\
\hline & & BV8S3 \\
\hline$\overline{\mathrm{B} 9 \mathrm{H}}$ & B variable 9 & BV9S1A1 \\
\hline & & BV9S1A2 \\
\hline$\overline{\mathrm{B} 11 \mathrm{H}}$ & B variable 11 & BV11S1A1 \\
\hline & & $\mathrm{BV} 11 \mathrm{~S} 1 \mathrm{~A} 2$ \\
\hline B12.1JLB/B12.2.3JLB & B variable 12 & BV12S1A1 \\
\hline & & BV12S2A1 \\
\hline & & BV12S2A2 \\
\hline & & BV12S2A3 \\
\hline & & BV12S3 \\
\hline$\overline{\mathrm{B} 13.1 \mathrm{eJLB} 2 / \mathrm{B} 13.5 \mathrm{JLB} !}$ & B variable 13 & BV13S1 \\
\hline & & BV13S2A1 \\
\hline & & BV13S3 \\
\hline & & BV13S4 \\
\hline & & BV13S5 \\
\hline & & BV13S6A1 \\
\hline & & BV13S6A2 \\
\hline & & BV13S6A3 \\
\hline & & BV13S6A4 \\
\hline & & BV13S7 \\
\hline$\overline{\text { B14JLB2 }}$ & B variable 14 & BV14S1 \\
\hline$\overline{\mathrm{B} 15 \mathrm{H}}$ & B variable 15 & BV15S1 \\
\hline $\mathrm{B} 16 \mathrm{H}$ & B variable 16 & BV16S1A1 \\
\hline$\overline{\text { B17Blum }}$ & B variable 17 & BV17S1A1 \\
\hline & & BV17S1A2 \\
\hline & & BV17S1A3 \\
\hline$\overline{B 18 J L B}$ & B variable 18 & BV18S1 \\
\hline$\overline{\text { B20JLB2 }}$ & B variable 20 & BV20S1A1 \\
\hline & & BV20S1A3 \\
\hline$\overline{B 21 J L B}$ & B variable 21 & BV21S1 \\
\hline & & BV21S2A1 \\
\hline & & $\mathrm{BV} 21 \mathrm{~S} 2 \mathrm{~A} 2$ \\
\hline & & $\mathrm{BV} 21 \mathrm{~S} 2 \mathrm{~A} 3$ \\
\hline & & BV21S3A1 \\
\hline & & BV21S3A2 \\
\hline$\overline{\mathrm{B} 22 \mathrm{H}}$ & B variable 22 & BV22S1A1 \\
\hline & & BV22S1A2 \\
\hline$\overline{\text { B23JLB2 }}$ & B variable 23 & BV23S1A1 \\
\hline & & BV23S1A2 \\
\hline$\overline{\mathrm{B} 24 \mathrm{H}}$ & B variable 24 & BV24S1A1 \\
\hline & & BV24S1A2 \\
\hline & & $\mathrm{BV} 24 \mathrm{~S} 1 \mathrm{~A} 3$ \\
\hline$\overline{B 25 J L B}$ & B variable 25 & BV25S1A1 \\
\hline & & BV25S1A3 \\
\hline$\overline{C B J L B}$ & B constant & $\mathrm{BC} 1$ \\
\hline & & $\mathrm{BC} 2$ \\
\hline TCRCB probe & B constant & $\mathrm{BC} 1$ \\
\hline & & $\mathrm{BC} 2$ \\
\hline
\end{tabular}

Table 1: TCRBV primer panel organization. 
The third column from the left in Table I, entitled TCR subfamily, contains all of the subfamily (S) and alleles (A) for a given TCR family, per the previously described nomenclature system ${ }^{3}$. The final two columns of Table I, titled TCR sequence and GenBank accession \#, provide the reference sequences used in the development of our primer sequences. When available, we have provided both the sequence clone name as well as its listing in the GenBank database. Primer sequences are proprietary and are available for licensing through the Institute for Scientific Research, Inc. (Fairmont, WV)

\section{Peripheral Blood Composition Analysis}

The cellular composition of the peripheral blood from three healthy human donors is presented in Table II. Cellular composition is as expected for healthy donors. It was found that lymphocyte samples range from 30\%-55\% CD4 ${ }^{+} \mathrm{T}$ cells, $22 \%-44 \%$ $\mathrm{CD}^{+} \mathrm{T}$ cells, and 4\%-11\% CD19 $\mathrm{B}$ cells.

\begin{tabular}{|c|c|c|c|c|c|c|c|}
\hline sample & $\begin{array}{c}\text { WBC } \\
\left(10^{3} / \mathrm{LL}\right)\end{array}$ & neutrophils & eosinophils & basophils & monocytes & lymphocytes & $\begin{array}{c}\text { CD19+ } \\
\text { CD4+ } \\
\text { CD8+ }\end{array}$ \\
\hline \multirow{3}{*}{ A } & \multirow{3}{*}{3.73} & \multirow{3}{*}{$57.00 \%$} & \multirow{3}{*}{$1.73 \%$} & \multirow{3}{*}{$0.69 \%$} & \multirow{3}{*}{$8.98 \%$} & \multirow{3}{*}{$31.60 \%$} & $4.11 \%$ \\
\hline & & & & & & & $54.75 \%$ \\
\hline & & & & & & & $21.65 \%$ \\
\hline \multirow{3}{*}{ B } & \multirow{3}{*}{3.38} & \multirow{3}{*}{$44.20 \%$} & \multirow{3}{*}{$8.08 \%$} & \multirow{3}{*}{$0.58 \%$} & \multirow{3}{*}{$6.51 \%$} & \multirow{3}{*}{$40.60 \%$} & $6.32 \%$ \\
\hline & & & & & & & $29.62 \%$ \\
\hline & & & & & & & $43.62 \%$ \\
\hline \multirow{3}{*}{ C } & \multirow{3}{*}{5.09} & \multirow{3}{*}{$57.40 \%$} & \multirow{3}{*}{$1.04 \%$} & \multirow{3}{*}{$0.79 \%$} & \multirow{3}{*}{$7.21 \%$} & \multirow{3}{*}{$33.60 \%$} & $10.61 \%$ \\
\hline & & & & & & & $40.07 \%$ \\
\hline & & & & & & & $25.16 \%$ \\
\hline
\end{tabular}

Table 2: Peripheral blood composition of donor samples.

All values are expressed as percent, except white blood cell (WBC) count, which is expressed as thousand cells/microliter. Lymphocyte counts were further differentiated into percent $C D 19^{+}, C D 4^{+}$ and $C D 8^{+}$as depicted in far right column. 


\section{iCycler $^{\mathrm{TM}}$ fluorescence signal corresponds to Southern Blot signal}

Figure 1 depicts the fluorescence readings obtained on the iCycler ${ }^{\mathrm{TM}}$ using the B1H/CBJLB primer set with the TCRCB TaqMan ${ }^{\circledR}$ probe. Fluorescence readings (RFU) are reported here as the $\mathrm{Ct}$ value, or the cycle at which fluorescence readings exceeded background fluorescence levels. Those samples with greater initial levels of target

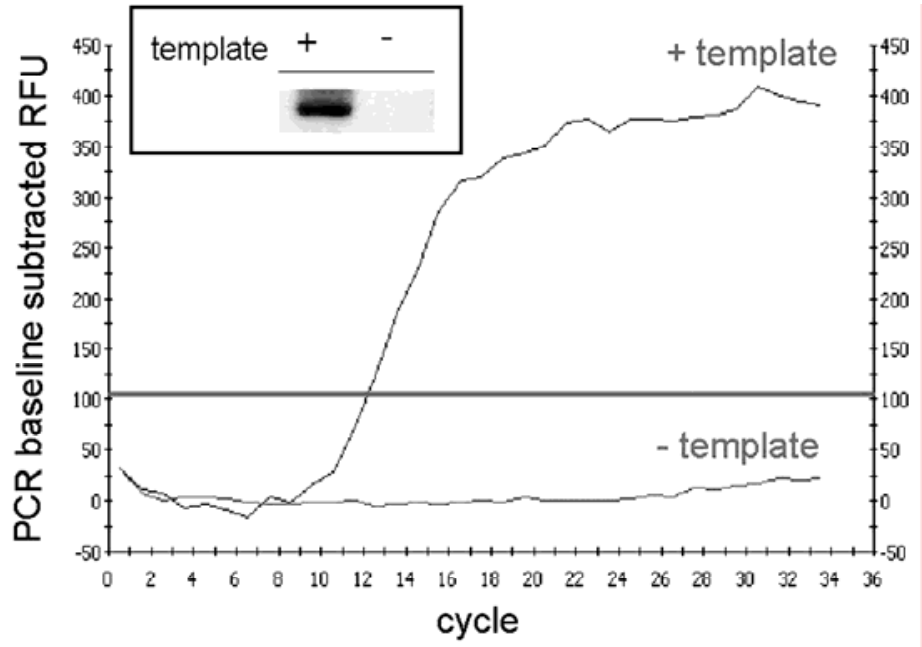

Figure 1: iCycler fluorescence readings during amplification of TCRBV1.

template have fluorescence levels that more quickly surpass these background fluorescence levels, or a lower Ct value, compared to samples with less initial copies of target template. The plus and minus template samples are indicated in Figure 1 . The plus template sample has a $\mathrm{Ct}$ value of 12 while the no template sample has an expected Ct value $>34$. Plus and minus template samples were completed for all TCR variable family primers to ensure the absence of autofluorescence in the no template samples. No significant autofluorescence levels were detected with the TCRBC TaqMan ${ }^{\circledR}$ probe and any of the TCRBV primers.

In order to confirm the fluorescence readings obtained by the iCycler ${ }^{\mathrm{TM}}$, Southern Blot analysis was performed on randomly chosen TCRBV PCR products. As exampled by the B1H/CBJLB amplification product shown as the inset in Figure 1, the iCycler's ${ }^{\mathrm{TM}}$ fluorescence readings are independently confirmed by Southern Blot analysis. Again, the plus and minus template samples are labeled accordingly in the inset of Figure 1. 


\section{Amplification Efficiency Determination}

cDNA was diluted into 10 fold serial dilutions and subjected to PCR amplification to determine the degree of amplification efficiency. Figure 2 depicts the fluorescence levels seen with the amplification reaction using the primer B6JLB2. The reaction using this primer was $\sim 93 \%$ efficient, results which are typical for the other analyzed primer sets. This amplification efficiency determination indicates that the PCR detection system is sensitive in response to the amount of target template initially placed into the reaction (refer to appendix for amplification efficiency calculation equation).

\section{TCRV family gene expression as determined by real-time PCR}

Figure 3 depicts the TCRBV expression profiles from three human peripheral blood samples. Each data point is the mean of triplicate reactions with the standard error of the mean indicated. One way Analysis of Variance with Tukey's Post Hoc test was performed for statistical analysis. Symbols indicate significant differences between the three samples for a given primer. $\$ \$(P<0.001)$, $\#(P<0.01)$, and $*(P<0.05)$. Significant differences in expression levels were seen between samples $A, B$, and C for TCRBV8, $12,15,16,17,18,20,23$, and 25. Both TCRBV mRNA and protein expression levels (determined using the IOTest ${ }^{\circledR}$ Beta Mark TCR VB Repertoire Kit (Beckman Coulter)) demonstrated steady state expression levels (refer to appendix for method and data). 

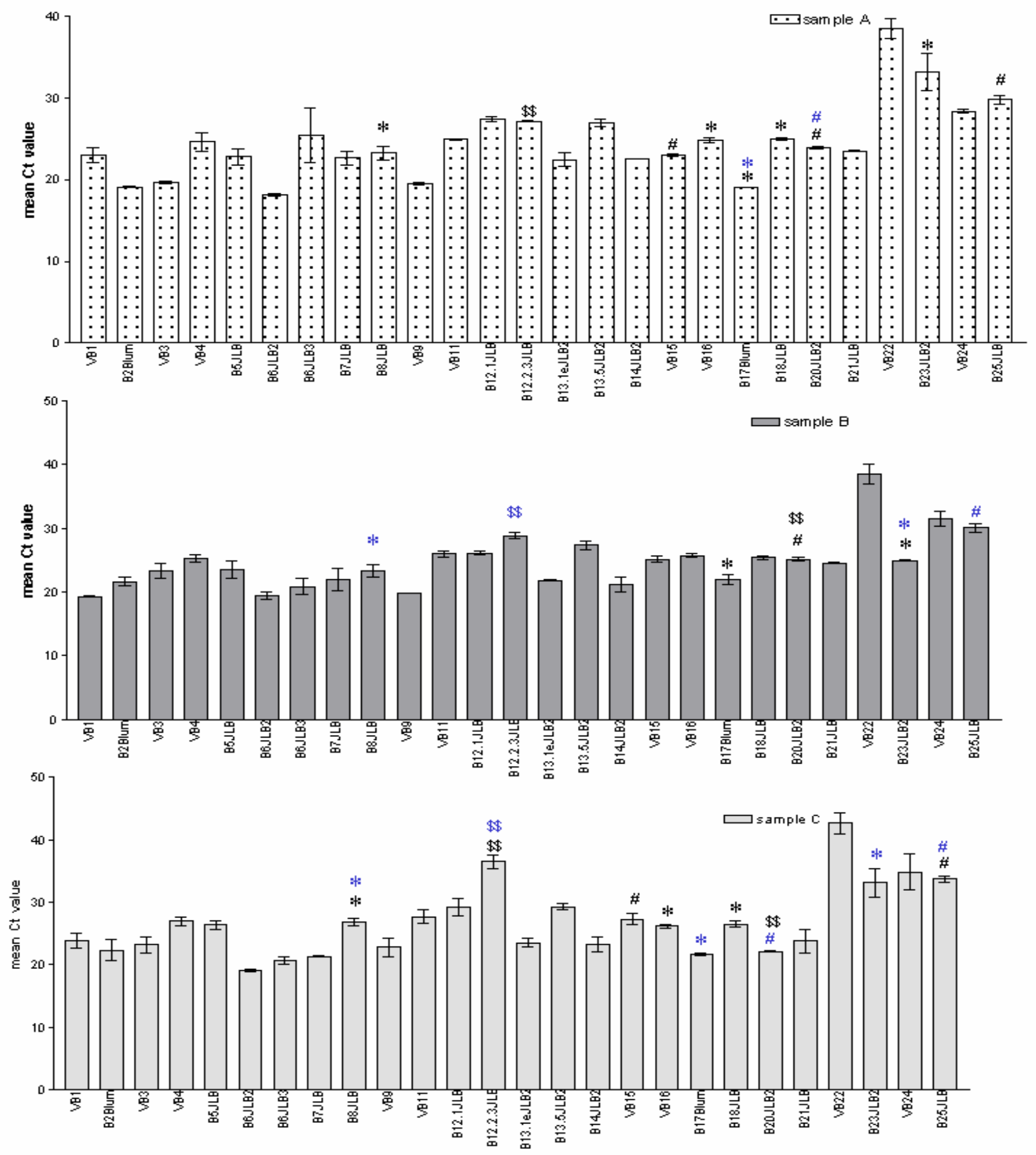

Figure 3: Relative TCRBV mRNA expression levels of three human peripheral blood samples based on Ct values

(samples $A, B$, and $C) . \$ \$(P<0.001)$, \# $(P<0.01)$, * $(P<0.05)$.

Note: A Ct difference of $\sim 3.5$ cycles was required to achieve $95 \%$ confidence, or $p<0.05$ 
Figure 4 depicts the relative TCRBV1 expression profile, as determined by $\mathrm{Ct}$ values, of a hematopoietic stem cell transplant patient prior to and following transplant. The patient was a 54 year-old male being treated for chronic lymphocytic leukemia and received peripheral blood hematopoietic stem cells from a matched related donor. The patient had a staphylococcus infection, as well as graft-versus-host disease and cytomegalovirus complications, immediately following transplant. These complications resolved but the patient expired at week 14 post- transplant from graft-versus-host disease complications. Significant changes in TCRBV1 expression were observed over time between weeks -1 and 3, weeks 3 and 4, weeks 7 and 8 , and weeks 8 and 9 .

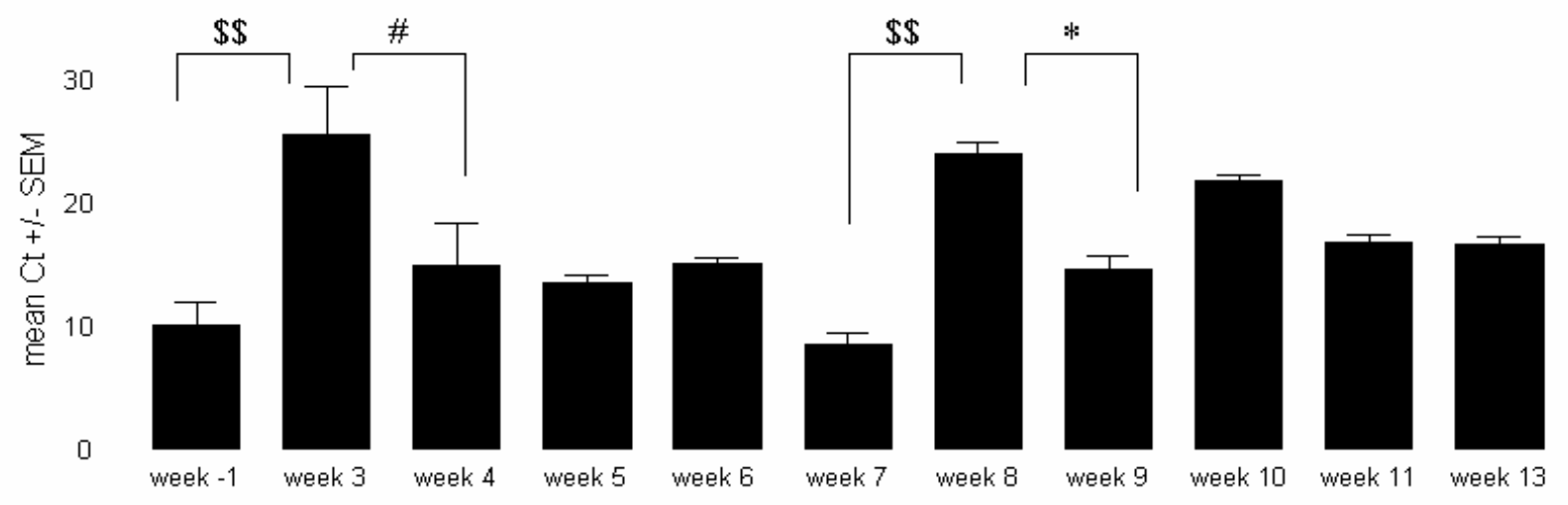

time post BMT

Figure 4:TCRBV1 expression level changes in a hematopoietic stem cell transplant recipient before and after transplant.

Each data point is the mean of triplicate reactions with the standard error of the mean indicated. One way Analysis of Variance with Bonferroni's Multiple Comparison test was performed for statistical analysis to monitor changes in the TCRBV1 expression from week-to-week. $\$ \$(P<0.001)$, $\#(P<0.01)$, and ${ }^{*}(P<0.05)$. 


\section{DISCUSSION}

Through the employment of primer panels previously developed ${ }^{4-49}$, many investigators have examined the usage of the human TCR beta variable genes under various biological conditions. Many of these reports, however, fall short of the desired comprehensiveness to detect all TCRBV members. For example, due to the more recent identification and classification of TCRBV families 21, 22, 23, 24, and 25, many previous reports do not include analysis of some or all of these additional five families ${ }^{4-}$ 17,20-30,32-39,41-43,45,46. Additionally many also would not amplify all subfamily and allele members within a given TCRBV family. For example, based on sequence homology analysis the panel proposed by Blumberg, et al., ${ }^{7}$ will not amplify the subfamily member BV8.3.

Others have tried different approaches to the amplification of all TCRBV subfamily and allele members. For example, Lynas, et al., ${ }^{28}$ describe the use of single primers to detect BV2/BV4 and BV18/BV8.3. Tsuruta, et al., ${ }^{44}$ have five separate primers in their panel to amplify all members of the TCRBV5 family while we have been able to identify a single primer sequence that we predict will amplify all 5 subfamilies (including all 11 possible alleles). Therefore, a primer panel that will amplify all possible alleles for the TCRBV families using as few primers as possible is a noteworthy improvement in the area of $\mathrm{T}$ cell receptor gene expression analysis, as sample availability is often a limiting factor.

While most of the previously cited primer panels we reviewed relied on conventional PCR, followed by gel analysis and Southern Blotting or the inclusion of labeled primers or nucleotides for sequence analysis there is at least one report of the use of TCRBV primers in a SYBR green reaction ${ }^{42}$. While the paper by Sebille et al., yields to the same primer sequence concerns as many of the others, as it traces its primer sequence roots back to the primers described by Genevee et al., ${ }^{15}$ and Gorski et al., ${ }^{17}$, this does move the field of TCRBV gene expression analysis into the real-time PCR arena. We have experimented with SYBR green reactions previously but prefer the ease of analysis and additional sequence specificity offered by a TaqMan ${ }^{\circledR}$ probe. 
While our study focuses on the use of peripheral blood samples, there is nothing intrinsic about our method that prevents using cells from other sources, for example cell cultures, tissue samples, or synovial fluid. We have previously used silica membranebased extraction kits, such as GenElute ${ }^{\mathrm{TM}}$ Mammalian Total RNA Kit (Sigma Chemical Co.), Rneasy ${ }^{\circledR}$ kit (Qiagen) and PAXgene ${ }^{\mathrm{TM}}$ Blood RNA kit (PreAnalytiX, Switzerland). However, we chose to isolate RNA from our samples using phenol-chloroform extraction, due to our success with improved yields compared to the silica membranebased technologies. While we chose to use the BioRad iCycler ${ }^{\text {TM }}$ due to its availability at our facilities, its larger sample capacity, and the permitted usage of conventional PCR tubes, we have previously used the Roche Lightcycler $^{\circledR}$, demonstrating the flexibility of platform usage but not validity that the primers provide equivalent results across all platforms.

Consistent with previous reports ${ }^{51-54}$, differences in TCRBV expression levels do exist between individuals and the level of those differences can change with time and health of the individual. Our technology has not only been demonstrated functional by the usage of sequence specific probes in real time PCR but has also been verified by Southern Blot analysis and flow cytometry utilizing available TCRBV antibodies, with the latter supporting the notion that the increased expression levels we observed with the PCR system were due to the increased number of cells expressing such receptors as opposed to only an increase in the amount of message in a given cell.

In terms of amplification efficiency, if a PCR reaction is $100 \%$ efficient, there will theoretically be a decrease in the $\mathrm{Ct}$ value by one each time the template amount is doubled (Roche Molecular Biochemicals, Technical Note No. LC 11/2000). Therefore, for a 10-fold dilution, a difference of 3.25 cycles should be observed between each 10fold dilution. Our methodology is not only comprehensive but it is also efficient with a typical amplification efficiency of $\geq 90 \%$.

In conclusion, we have presented here a significant improvement to existing technologies that enable one to detect all of the families, subfamilies, and alleles of the TCRBV regions classified by Arden et al., ${ }^{3}$ using efficient, sequence specific real-time PCR methodology. The user benefits from automated and integrated amplification, detection, and analysis in a gel free environment with the choice of using various PCR 
platforms, sample sources, and sample processing methods. Additionally, this PCRbased method is approximately 25 -fold less expensive than comparable flow cytometry based methods. This technology can be applied to any area of study examining $T$ cell biology, including autoimmunity, transplantation, cancer therapy, and infectious disease. 


\section{REFERENCES}

(1) von Boehmer $\mathrm{H}$. The developmental biology of T lymphocytes. Annu Rev Immunol. 1988;6:309-326.

(2) Saiki RK, Gelfand DH, Stoffel S et al. Primer-directed enzymatic amplification of DNA with a thermostable DNA polymerase. Science. 1988;239:487-491.

(3) Arden B, Clark SP, Kabelitz D, Mak TW. Human T-cell receptor variable gene segment families. Immunogenetics. 1995;42:455-500.

(4) Abe J, Forrester J, Nakahara T et al. Selective stimulation of human T cells with streptococcal erythrogenic toxins A and B. J Immunol. 1991;146:37473750 .

(5) Abe J, Kotzin BL, Jujo K et al. Selective expansion of T cells expressing T-cell receptor variable regions $\mathrm{V}$ beta 2 and $\mathrm{V}$ beta 8 in Kawasaki disease. Proc Natl Acad Sci U S A. 1992;89:4066-4070.

(6) Ben Nun A, Liblau RS, Cohen $L$ et al. Restricted T-cell receptor $V$ beta gene usage by myelin basic protein-specific T-cell clones in multiple sclerosis: predominant genes vary in individuals. Proc Natl Acad Sci U S A. 1991;88:2466-2470.

(7) Blumberg RS, Yockey CE, Gross GG, Ebert EC, Balk SP. Human intestinal intraepithelial lymphocytes are derived from a limited number of $\mathrm{T}$ cell clones that utilize multiple $\vee$ beta T cell receptor genes. J Immunol. 1993;150:51445153.

(8) Bragado R, Lauzurica P, Lopez D, Lopez de Castro JA. T cell receptor V beta gene usage in a human alloreactive response. Shared structural features among HLA-B27-specific T cell clones. J Exp Med. 1990;171:1189-1204. 
(9) Choi YW, Kotzin B, Herron L et al. Interaction of Staphylococcus aureus toxin "superantigens" with human T cells. Proc Natl Acad Sci U S A. 1989;86:89418945.

(10) Dietrich PY, Caignard A, Diu A et al. Analysis of T-cell receptor variability in transplanted patients with acute graft-versus-host disease. Blood. 1992;80:2419-2424.

(11) Dietrich PY, Caignard A, Lim A et al. In vivo T-cell clonal amplification at time of acute graft-versus-host disease. Blood. 1994;84:2815-2820.

(12) Dombret H, Loiseau P, Bories JC, Sigaux F. Unexpected consistent involvement of $\mathrm{V}$ beta gene segments in inappropriate $\mathrm{T}$-cell receptor beta gene rearrangements occurring in B-lineage acute lymphoblastic leukemias. Blood. 1992;80:2614-2621.

(13) Even J, Lim A, Puisieux I et al. T-cell repertoires in healthy and diseased human tissues analysed by T-cell receptor beta-chain CDR3 size determination: evidence for oligoclonal expansions in tumours and inflammatory diseases. Res Immunol. 1995;146:65-80.

(14) Gagne K, Brouard S, Giral M et al. Highly altered V beta repertoire of T cells infiltrating long-term rejected kidney allografts. J Immunol. 2000;164:15531563.

(15) Genevee C, Diu A, Nierat J et al. An experimentally validated panel of subfamily-specific oligonucleotide primers ( $V$ alpha 1-w29/V beta 1-w24) for the study of human $\mathrm{T}$ cell receptor variable $\mathrm{V}$ gene segment usage by polymerase chain reaction. Eur J Immunol. 1992;22:1261-1269.

(16) Gorochov G, Debre P, Leblond V et al. Oligoclonal expansion of CD8+ CD57+ T cells with restricted T-cell receptor beta chain variability after bone marrow transplantation. Blood. 1994;83:587-595. 
(17) Gorski J, Yassai M, Zhu $X$ et al. Circulating $T$ cell repertoire complexity in normal individuals and bone marrow recipients analyzed by CDR3 size spectratyping. Correlation with immune status. J Immunol. 1994;152:51095119.

(18) Hirokawa M, Matsutani T, Horiuchi $T$ et al. Extensive clonal expansion of $T$ lymphocytes causes contracted diversity of complementarity-determining region 3 and skewed T cell receptor repertoires after allogeneic hematopoietic cell transplantation. Bone Marrow Transplant. 2001;27:607-614.

(19) Hirokawa M, Matsutani T, Saitoh $\mathrm{H}$ et al. Distinct TCRAV and TCRBV repertoire and CDR3 sequence of T lymphocytes clonally expanded in blood and GVHD lesions after human allogeneic bone marrow transplantation. Bone Marrow Transplant. 2002;30:915-923.

(20) Ikeda $\mathrm{H}$, Sato N, Matsuura A, Kikuchi K. Analysis of T-cell receptor $V$ region gene usage of cytotoxic T-lymphocytes and tumor-infiltrating lymphocytes derived from human autologous gastric signet ring cell carcinomas. Cancer Res. 1993;53:3078-3084.

(21) Kalams SA, Johnson RP, Trocha AK et al. Longitudinal analysis of $T$ cell receptor (TCR) gene usage by human immunodeficiency virus 1 envelopespecific cytotoxic T lymphocyte clones reveals a limited TCR repertoire. J Exp Med. 1994;179:1261-1271.

(22) Kalams SA, Johnson RP, Dynan MJ et al. T cell receptor usage and fine specificity of human immunodeficiency virus 1-specific cytotoxic $\mathrm{T}$ lymphocyte clones: analysis of quasispecies recognition reveals a dominant response directed against a minor in vivo variant. J Exp Med. 1996;183:1669-1679.

(23) Kubo $\mathrm{H}$, Abe J, Obata $\mathrm{F}$ et al. Dual recognition of a human cytotoxic T-cell clone for melanoma antigens. Cancer Res. 1996;56:2368-2374. 
(24) Kuijpers KC, van Dongen JJ, van der BP et al. A combined immunodeficiency with oligoclonal CD8+, $\mathrm{V}$ beta 3-expressing, cytotoxic $\mathrm{T}$ lymphocytes in the peripheral blood. J Immunol. 1992;149:3403-3410.

(25) Kusaka S, Grailer AP, Fechner JH, Jr. et al. Clonotype analysis of human alloreactive T cells: a novel approach to studying peripheral tolerance in a transplant recipient. J Immunol. 2000;164:2240-2247.

(26) Lang $\mathrm{R}$, Pfeffer $\mathrm{K}$, Wagner $\mathrm{H}$, Heeg K. A rapid method for semiquantitative analysis of the human $\mathrm{V}$ beta-repertoire using TaqManR PCR. J Immunol Methods. 1997;203:181-192.

(27) Liu X, Chesnokova V, Forman SJ, Diamond DJ. Molecular analysis of T-cell receptor repertoire in bone marrow transplant recipients: evidence for oligoclonal T-cell expansion in graft-versus-host disease lesions. Blood. 1996;87:3032-3044.

(28) Lynas C, Howe D. Additional TCRV beta primers and minor method modifications improve detection of clonal T-cell populations by RT-PCR. Mol Pathol. 1997;50:53-55.

(29) Margolis DA, Casper JT, Segura AD et al. Infiltrating T cells during liver graftversus-host disease show a restricted T-cell repertoire. Biol Blood Marrow Transplant. 2000;6:408-415.

(30) Maslanka K, Piatek T, Gorski J, Yassai M, Gorski J. Molecular analysis of T cell repertoires. Spectratypes generated by multiplex polymerase chain reaction and evaluated by radioactivity or fluorescence. Hum Immunol. 1995;44:28-34.

(31) Matsutani T, Yoshioka T, Tsuruta Y, Iwagami S, Suzuki R. Analysis of TCRAV and TCRBV repertoires in healthy individuals by microplate hybridization assay. Hum Immunol. 1997;56:57-69. 
(32) Matsutani T, Yoshioka T, Tsuruta $Y$ et al. Restricted usage of T-cell receptor alpha-chain variable region (TCRAV) and T-cell receptor beta-chain variable region (TCRBV) repertoires after human allogeneic haematopoietic transplantation. Br J Haematol. 2000;109:759-769.

(33) McCarthy KP, Sloane JP, Kabarowski JH, Matutes E, Wiedemann LM. The rapid detection of clonal T-cell proliferations in patients with lymphoid disorders. Am J Pathol. 1991;138:821-828.

(34) Nuovo GJ, Morrison C, Porcu P, Caligiuri MA, Suster S. In situ determination of T-cell receptor beta expression patterns. J Histochem Cytochem. 2001;49:139-145.

(35) Oaks MK, Downs JA, Tector AJ. T-cell receptor alpha and beta chain gene expression in cells infiltrating human cardiac allografts. Am J Med Sci. 1995;309:26-34.

(36) Orsini E, Alyea EP, Schlossman R et al. Changes in T cell receptor repertoire associated with graft-versus-tumor effect and graft-versus-host disease in patients with relapsed multiple myeloma after donor lymphocyte infusion. Bone Marrow Transplant. 2000;25:623-632.

(37) Panzara MA, Gussoni E, Steinman L, Oksenberg JR. Analysis of the T cell repertoire using the PCR and specific oligonucleotide primers. Biotechniques. 1992;12:728-735.

(38) Pilch $\mathrm{H}$, Hohn $\mathrm{H}$, Freitag $\mathrm{K}$ et al. Improved assessment of $\mathrm{T}$-cell receptor (TCR) VB repertoire in clinical specimens: combination of TCR-CDR3 spectratyping with flow cytometry-based TCR VB frequency analysis. Clin Diagn Lab Immunol. 2002;9:257-266.

(39) Puisieux I, Even J, Pannetier C et al. Oligoclonality of tumor-infiltrating lymphocytes from human melanomas. J Immunol. 1994;153:2807-2818. 
(40) Roers A, Montesinos-Rongen M, Hansmann ML, Rajewsky K, Kuppers R. Amplification of TCRbeta gene rearrangements from micromanipulated single cells: T cells rosetting around Hodgkin and Reed-Sternberg cells in Hodgkin's disease are polyclonal. Eur J Immunol. 1998;28:2424-2431.

(41) Sarzotti M, Patel DD, Li X et al. T cell repertoire development in humans with SCID after nonablative allogeneic marrow transplantation. J Immunol. 2003;170:2711-2718.

(42) Sebille F, Gagne K, Guillet $M$ et al. Direct recognition of foreign MHC determinants by naive $T$ cells mobilizes specific Vbeta families without skewing of the complementarity-determining region 3 length distribution. $\mathrm{J}$ Immunol. 2001;167:3082-3088.

(43) Smith TJ, Terada N, Robinson CC, Gelfand EW. Acute infectious mononucleosis stimulates the selective expression/expansion of $\mathrm{V}$ beta 6.1-3 and $\mathrm{V}$ beta 7 T cells. Blood. 1993;81:1521-1526.

(44) Tsuruta Y, Yoshioka T, Suzuki R, Sakata T. Analysis of the population of human $\mathrm{T}$ cell receptor gamma and delta chain variable region subfamilies by reverse dot blot hybridization. J Immunol Methods. 1994;169:17-23.

(45) Tsutsumi Y, Tanaka J, Sugita J et al. Analysis of T-cell repertoire and mixed chimaerism in a patient with aplastic anaemia after allogeneic bone marrow transplantation. Br J Haematol. 2002;118:136-139.

(46) Ueda D, Sato N, Matsuura A et al. T-cell receptor gene structures of HLAA26-restricted cytotoxic $T$ lymphocyte lines against human autologous pancreatic adenocarcinoma. Jpn J Cancer Res. 1995;86:691-697.

(47) Willenbrock K, Roers A, Blohbaum B, Rajewsky K, Hansmann ML. CD8(+) T cells in Hodgkin's disease tumor tissue are a polyclonal population with limited clonal expansion but little evidence of selection by antigen. Am J Pathol. 2000;157:171-175. 
(48) Wucherpfennig KW, Ota $\mathrm{K}$, Endo $\mathrm{N}$ et al. Shared human $\mathrm{T}$ cell receptor $\mathrm{V}$ beta usage to immunodominant regions of myelin basic protein. Science. 1990;248:1016-1019.

(49) Yoshioka T, Matsutani T, Iwagami S et al. Quantitative analysis of the usage of human $T$ cell receptor alpha and beta chain variable regions by reverse dot blot hybridization. J Immunol Methods. 1997;201:145-155.

(50) Don RH, Cox PT, Wainwright BJ, Baker K, Mattick JS. 'Touchdown' PCR to circumvent spurious priming during gene amplification. Nucleic Acids Res. 1991;19:4008.

(51) Akolkar PN, Gulwani-Akolkar B, Pergolizzi R, Bigler RD, Silver J. Influence of HLA genes on $\mathrm{T}$ cell receptor $\mathrm{V}$ segment frequencies and expression levels in peripheral blood lymphocytes. J Immunol. 1993;150:2761-2773.

(52) DeBruyne LA, Lynch JP, III, Baker LA et al. Restricted $V$ beta usage by $T$ cells infiltrating rejecting human lung allografts. J Immunol. 1996;156:34933500 .

(53) Lima M, Teixeira MA, Queiros ML et al. Immunophenotype and TCR-Vbeta repertoire of peripheral blood T-cells in acute infectious mononucleosis. Blood Cells Mol Dis. 2003;30:1-12.

(54) Soroosh P, Shokri F, Azizi M, Jeddi-Tehrani M. Analysis of T-cell receptor beta chain variable gene segment usage in healthy adult responders and nonresponders to recombinant hepatitis B vaccine. Scand J Immunol. 2003;57:423-431. 
THE PREVIOUS CHAPTER DESCRIBED THE DEVELOPMENT OF IMPROVED TECHNOLOGY CAPABLE OF ACCURATELY AND EFFICIENTLY DETECTING EXPRESSION OF ALL OF THE HUMAN TCRBV GENES.

THERE ARE MANY POTENTIAL APPLICATIONS OF SUCH TECHNOLOGY.

FOR MY PURPOSES, HOWEVER, I UTILIZED THE TECHNOLOGY TO DETERMINE WHAT SPECIFIC T CELLS ARE ASSOCIATED WITH THE FOLLOWING SPECIFIC EVENTS AFTER ALLOGENEIC HEMATOPOIETIC STEM CELL TRANSPLANTATION:

1) GRAFT-VERSUS-HOST DISEASE

2) CYTOMEGALOVIRUS REACTIVATION

3) IMMUNOSUPPRESSIVE THERAPIES (CYCLOSPORIN A AND TACROLIMUS)

4) ENGRAFTMENT OF THE TCRBV REPERTOIRE 


\section{CHAPTER 3}

SIMILARITY IN REPERTOIRE OF T CELLS ASSOCIATED WITH OCCURRENCES OF CMV REACTIVATION AND GVHD POST HUMAN HEMATOPOIETIC STEM CELL TRANSPLANTATION. 


\section{ABSTRACT}

Cytomegalovirus (CMV), after initial infection, typically remains in a latent state and reactivates during periods of immune suppression, such as after allogeneic hematopoietic stem cell (HSC) transplant. Prior studies have indicated a restricted usage of specific TCRBV families directed against CMV antigens in otherwise healthy individuals. We monitored, on a weekly basis, the usage of the T cell receptor beta variable (TCRBV) repertoire in the peripheral blood of five HSC transplant recipients using real-time RT-PCR and found that several TCRBV families (TCRBV 1-6, 11, 12.1, 13 (excluding 13.5), 15, 16, 20, 25) were significantly associated with CMV reactivation. In addition, significant overlap exists in these families and those found to be associated with graft-versus-host disease (GVHD), a common T cell mediated post transplant complication. Our results may help to explain the common clinical association of CMV reactivation and GVHD.

\section{INTRODUCTION}

Cytomegalovirus (CMV) is a human herpes virus that infects greater than $60 \%$ of the world's adult population ${ }^{1}$. While this virus typically presents itself as a latent infection, it commonly reactivates during immuno-suppressed states, such as after allogeneic hematopoietic stem cell transplant (HSCT) ${ }^{2}$. Prior studies have indicated a restricted usage of specific $T$ cell receptor beta variable (TCRBV) families directed against CMV antigens in otherwise healthy individuals ${ }^{3-6}$. We here examine the expression of specific TCRBV families associated with CMV reactivation following allogeneic hematopoietic stem cell (HSC) transplantation. In addition, we determined that overlap exists in the TCRBV families associated with CMV reactivation and graftversus-host disease (GVHD), supporting previous reports of the clinical association of GVHD and CMV reactivation ${ }^{7-9}$. GVHD is a common post transplant complication where the donor-derived T cells attack and destroy the recipient's tissue based upon allogeneic disparities between the $T$ cell receptor (TCR) and peptide:major histocompatibility complex ( $\mathrm{p}: \mathrm{MHC})^{10}$. In our study peripheral blood samples were collected weekly from allogeneic HSC recipients through day 100 post-transplant. Donor 
and recipient peripheral blood samples were also collected prior to pre-transplant conditioning therapies in order to serve as baseline reference samples. Despite the complexities of the post transplant environment, we found that specific subsets of $T$ cells were significantly associated with CMV reactivation and that many of these same TCRBV families were also associated with the development of GVHD in the patient population studied.

\section{MATERIALS AND METHODS}

\section{Patient population}

Study subjects were patients undergoing allogeneic transplant treatment at West Virginia University's Blood and Marrow Transplant and Hematological Malignancy Program, Morgantown, West Virginia (Table 1). Informed consent was obtained from participants after the nature and possible consequences of the study had been fully explained according to West Virginia University's Institutional Review Board guidelines. Prior to peripheral blood stem cell (PBSC) infusion, study recipients underwent myeloblative conditioning regimens consisting of either Thiotepa $\left(500 \mathrm{mg} / \mathrm{m}^{2} \mathrm{q} 12 \mathrm{~h} \times 2\right.$ doses), Campath-1H (20mg $\times 2$ doses), and total body irradiation (TBI) (200 cGy x 5 fractions) or Busulfan (1mg/kg p.o. q6h $\times 16$ doses) and Cytoxan (60 mg/kg/d $\times 2$ doses). A $20 \mathrm{~mL}$ peripheral blood sample was collected weekly, via venipuncture from hematopoietic stem cell transplant patients, into an acid citrate dextrose VACUTAINER $^{\text {TM }}$ blood collection tube (Becton Dickinson, Franklin Lakes, NJ, USA). Buffy coat layers were isolated via centrifugation at $3300 \mathrm{rcf}$ for 10 minutes. Contaminating red blood cells were removed by hypotonic lysis. 


\begin{tabular}{|c|c|c|c|c|c|c|c|}
\hline recipient & sex & age & disease & donor & $\begin{array}{l}\text { pretreatment } \\
\text { regimen }\end{array}$ & $\begin{array}{l}\mathrm{CMV} \text { status } \\
\text { recipient/donor }\end{array}$ & $\begin{array}{l}\text { post tranplant } \\
\text { complications }\end{array}$ \\
\hline 1 & $M$ & 54 & AML & MRD & TT/TBI/Campath & neg/neg & $\begin{array}{c}\text { GVHD grade I } \\
\text { bacterial pneumonia } \\
\text { viral mouth sores } \\
\text { staphylococcus infection } \\
\text { bacterial URI/sinusitis }\end{array}$ \\
\hline 2 & M & 54 & CLL & MRD & TT/TBI/Campath & pos/neg & $\begin{array}{l}\text { GVHD grades II and IV } \\
\text { CMV reactivation } \\
\text { staphylococcus infection }\end{array}$ \\
\hline 3 & $\mathrm{M}$ & 51 & $\mathrm{NHL}$ & MRD & TT/TBI/Campath & pos/neg & $\begin{array}{c}\text { GVHD grade II } \\
\text { CMV reactivation } \\
\text { staphylococcus infection }\end{array}$ \\
\hline 4 & $\mathrm{~F}$ & 41 & CML & MRD & TT/TBI/Campath & neg/neg & $\begin{array}{c}\text { GVHD grade III } \\
\text { C. difficile } \\
\text { viral mouth sores } \\
\text { Enterococcus faecalis }\end{array}$ \\
\hline 5 & $F$ & 41 & CML & MUD & Bu/Cy2 & pos/pos & $\begin{array}{c}\text { GVHD grade II } \\
\text { CMV reactivation } \\
\text { bacterial gastritis } \\
\text { Cornybacter diptheroid }\end{array}$ \\
\hline
\end{tabular}

Table 1: Patient demographics

All patients received peripheral blood hematopoietic stem cell transplants from an HLA-matched related donor (MRD) with the exception of recipient 5, who received stem cells from an HLA-matched unrelated donor (MUD). HLA matching was performed serologically for all MRD but was determined using molecular typing for MUD. Cytomegalovirus (CMV) status was determined in both recipient and donor prior to transplant by evaluating CMV IgG and IgM serum levels. CMV reactivation was monitored weekly by antigenemia testing for recipients at risk for CMV reactivation (donor and/or recipient with prior history of CMV exposure). Complications experienced in the recipient post transplant, as determined by standard clinical evaluation, are indicated on the far right side of the table. All patients were living at the conclusion of our study. Abbreviations: M, male; F, female; AML, acute myelogenous leukemia; CLL, chronic lymphocytic leukemia; NHL, non-Hodgkin lymphoma; CML, chronic myelogenous leukemia; TT, Thiotepa; TBI, total body irradiation; Bu, Busulfan; Cy2, Cytoxan; GVHD, graft-versus-host disease. 


\section{Donors}

All donors were serologically HLA matched to the recipient at a minimum of HLAA, B, and DR loci. The patient undergoing an unrelated donor transplants was also molecularly matched at the allele level. PBSC donors were mobilized with filgrastim (GCSF) at $10 \mathrm{ug} / \mathrm{kg} /$ day for 5 days with stem cell collection occurring on day 5 . The number of PBSC collected was $3-5 \times 10^{6} \mathrm{HSC} / \mathrm{kg}$ of recipient body weight.

\section{GVHD Prophylaxis and Supportive Care}

Cyclosporin A (CSA) or tacrolimus (FK506) treatment started one day before transplant (d-1) as part of standard graft-versus-host disease prophylaxis and continued throughout the study period. The patients also received pulse methotrexate as part of GVHD prophylaxis. Patients were monitored bi-weekly for CSA and FK506 serum concentrations, with dosages adjusted as necessary to be within the preferred protocol serum concentrations of $200+/-20 \mathrm{ng} / \mathrm{mL}$ for CSA and $7-12 \mathrm{ng} / \mathrm{mL}$ for FK506. Additional supportive care, including anti-fungal, anti-viral, and anti-PCP prophylaxis were provided according to standard operating policies. CMV reactivation was monitored weekly by antigenemia testing (ViroMed Laboratories, Inc., Minnetonka, MN).

\section{RNA Isolation}

Total RNA was isolated from 20-40 x $10^{6}$ white blood cells using TRIzol ${ }^{\circledR}$ Reagent according to the manufacturer's directions (Ambion, Austin, TX, USA). RNA was dissolved in ultra-PURE ${ }^{\mathrm{TM}}$ Distilled DNAse and RNAse free water (Invitrogen Corporation, Carlsbad, CA, USA). DNase treatment was performed on isolated RNA according to the manufacturer's recommendations using DNA-free ${ }^{\mathrm{TM}}$ (Ambion, Austin, TX, USA). RNA purity and concentration was determined by standard 260nm:280nm spectrophotometric analysis using a Genesis 10UV Spectronic Unicam (Spectronic Instruments, Rochester, NY, USA). 


\section{$R T-P C R$}

One Step RT-PCR was performed using the QuantiTect ${ }^{\mathrm{TM}}$ Probe RT-PCR kit (Qiagen, Valencia, CA, USA). Recommended reaction mixtures were scaled down to a total reaction volume of $20 \mu \mathrm{L}$ using $0.04 \mu \mathrm{g}$ RNA with the following primer and probe concentrations: $0.4 \mu \mathrm{M}$ TCRBV primer (Biosource International, Camarillo, CA, USA), $0.4 \mu \mathrm{M}$ TCRBC primer (Biosource International, Camarillo, CA, USA), and $0.2 \mu \mathrm{M}$ TCRBC TaqMan ${ }^{\circledR}$ probe, 5' 6-FAM, 3' BHQ ${ }^{\mathrm{TM}}-1$ (Integrated DNA Technologies, Inc., Coralville, IA, USA). 18SrRNA control reactions were performed in parallel using $0.4 \mu \mathrm{M}$ each of sense and anti-sense primers (Biosource International, Camarillo, CA, USA) and $0.2 \mu \mathrm{M}$ 18SrRNA TaqMan $^{\circledR}$ probe, 5' 6-FAM, 3' BHQ ${ }^{\text {TM }}-1$ (Integrated DNA Technologies, Inc., Coralville, IA, USA). Primer and probe sequences were previously described (Brewer and Ericson, J. of Immunol. Methods, in press). An iCycler ${ }^{\mathrm{TM}}$ (BioRad Laboratories, Hercules, CA, USA) was used for the RT and amplification cycles. RT was performed at $50^{\circ} \mathrm{C}$ for 60 minutes, max ramp speed, followed by an initial Taq activation step of 15 minutes at $95^{\circ} \mathrm{C}$, max ramp speed. A TouchDown PCR approach ${ }^{11}$ was used with the following cycling conditions: denaturation for 15 seconds at $95^{\circ} \mathrm{C}$, max ramp speed, annealing for 30 seconds starting at $70^{\circ} \mathrm{C}$ decreasing by $2^{\circ} \mathrm{C}$ for 10 repeats, max ramp speed, and extension for 40 seconds at $72^{\circ} \mathrm{C}$, min ramp speed. After this TouchDown of the annealing temperature, 50 cycles were performed as follows with the optical data collection occurring at the extension step: 15 seconds at $95^{\circ} \mathrm{C}$ (max ramp speed), 30 seconds at $52^{\circ} \mathrm{C}$ (max ramp speed), and 40 seconds at $60^{\circ} \mathrm{C}$ (min ramp speed). Reactions were held at $4^{\circ} \mathrm{C}$ upon the conclusion of the run.

\section{Statistical Analyses}

One-way analysis of variance with Bonferroni's Multiple Comparison Test was used to determine the TCRBV families associated with GVHD and CMV reactivation. 


\section{RESULTS}

Increased expression of specific TCRBV families is associated with reactivation of cytomegalovirus post peripheral blood hematopoietic stem cell transplant.

Using serial time points, we analyzed the alterations in TCRBV expression over time to determine which TCRBV families were associated with CMV reactivation compared to periods without CMV reactivation. All patients in our study were determined to be $100 \%$ donor engrafted at day 30 post-transplant, with the exception of recipient 5, whose chimerism analysis was not performed until day 100 post transplant, at which point chimerism was also determined to be $100 \%$ donor in origin. We found an increase in the expression of TCRBV families 1-6, 11, 12.1, 13 (excluding 13.5), 15, 16, 20 , and 25 with CMV reactivation compared to sampling periods in which CMV antigenemia was not detected (Table 2).

Increased expression of specific TCRBV families is associated with Graft-versusHost Disease post peripheral blood hematopoietic stem cell transplant and has significant similarity to those families linked to CMV reactivation.

In addition to investigating the increased expression of specific TCRBV families in the setting of CMV reactivation, we also examined the expression profiles of TCRBV families associated with GVHD post HSC transplant. By weekly monitoring of the T cell repertoire, in addition to baseline sampling, we were able to circumvent some of the concerns associated with previous GVHD reports, such as the lack of baseline samples and serial time point analyses ${ }^{12-17}$. All five of our patients developed acute GVHD post HSCT, primarily grades I-II (Table 1). When we examined the TCRBV expression profile during periods when patients had GVHD and compared this to periods without GVHD, we found significant increases in the expression of TCRBV 1-6, 12.1, 13 (excluding 13.5), and 16, associated with GVHD grades I-II, with an additional increase in TCRBV 18 seen in a patient with GVHD grade IV (Table 2). 


\begin{tabular}{|cc|}
\hline $\begin{array}{c}\text { TCRBV increases associated with } \\
\text { CMV reactivation }\end{array}$ & $\begin{array}{c}\text { TCRBV increases associated with } \\
\text { GVHD grade I/II }\end{array}$ \\
\hline 1 & 1 \\
2 & 2 \\
3 & 3 \\
4 & 4 \\
5 & 5 \\
6 & 6 \\
11 & 12.1 \\
12.1 & 13 (excluding 13.5) \\
13 (excluding 13.5) & 16 \\
15 & ${ }^{\star} 18$ \\
16 & \\
20 & \\
25 & \\
\hline
\end{tabular}

Table 2: Increased expression of specific families of TCRBV is associated with cytomegalovirus (CMV) reactivation and Graft-versus-Host Disease (GVHD) post peripheral blood stem cell transplant.

Specific TCRBV families were significantly increased $(p<0.05)$ with the occurrence of CMV reactivation, compared to periods in which CMV antigenemia was not detected and also with the occurrence of GVHD grades I and II, compared to periods without GVHD complications. *In a patient with grade IV GVHD an increase in TCRBV18 was seen in addition to the increase in TCRBV families seen in GVHD grades I-II.

\section{DISCUSSION}

A number of studies have examined the role of specific $T$ cells in the immune response to CMV antigens. While a previous study looking at the TCRBV expression during CMV reactivation in kidney and liver transplants found no preference for TCRBV usage ${ }^{18}$, we found great similarity in our results and those examining the TCRBV expression of CMV reactive $T$ cells found in otherwise healthy individuals ${ }^{3-6}$. For example, studies using CMV reactive $T$ cell from healthy donors expressed TCRBV families 2 and $20^{6}$, TCRBV families $3,6.7,13.1$, and $20^{5}$, and TCRBV families 1,2 , $5.1,12,13.1$, and $16^{3}$. Many of these previous studies utilized tetramer technology to remove CMV reactive $T$ cells, which were then analyzed for TCRBV expression via antibody staining and flow cytometry. The greatest limitation of previously described 
studies is that antibodies were not available to all of the TCRBV families, such as TCRBV $4,11,13,15$, and sometimes 25 . We suspect that the reason we detected the expression of additional TCRBV families with CMV reactivation compared to these previous studies was that we used a primer panel that could detect all of the TCRBV families and their alleles.

Similarly a number of reports have described the association of specific TCRBV families with GVHD, with some of these studies not only examining peripheral blood samples but also GVHD tissue lesions 12-17,19-25. Many of these studies, however, contained very limited numbers of sampling points; for example some studies primarily evaluated samples upon the diagnosis of GVHD and others did not contain baseline sampling ${ }^{12-17}$. In this aspect, our study significantly adds to the investigation of immune response after hematopoietic stem cell (HSC) transplantation by providing serial time point analyses using a comprehensive primer panel, which can detect all TCRBV families and alleles.

Several reports have detailed the clinical association of GVHD and CMV reactivation ${ }^{7-9}$. Larsson et al., observed a decreased risk for the development of GVHD when patients were preemptively treated with anti-viral therapy ${ }^{7,8}$ while Vassallo et al., observed an association between skin GVHD and the presence of CMV antigens in the patient's peripheral blood ${ }^{9}$. A recently published study noted cross reactivity of an HLADR7 restricted CMV-specific T cell for an HLA-DR4 allo-antigen ${ }^{7}$. This could possibly account for the overlap we saw in TCRBV families associated with both GVHD and CMV reactivation.

In conclusion, the developing immune system found in hematopoietic stem cell transplant patients responds to CMV antigen exposure with the alteration of the TCRBV profile with great similarity to that described in prior non-transplant related reports. Additionally, great similarities exist in the alterations of the TCRBV profile associated with CMV reactivation and the occurrence of GVHD, supporting prior reports of such a clinical association. 


\section{REFERENCE LIST}

(1) Roullet E. Opportunistic infections of the central nervous system during HIV-1 infection (emphasis on cytomegalovirus disease). J Neurol. 1999;246:237-243.

(2) Wingard JR. Opportunistic infections after blood and marrow transplantation. Transplant Infectious Disease. 1999;1:3-20.

(3) Bitmansour AD, Waldrop SL, Pitcher CJ et al. Clonotypic structure of the human CD4+ memory $\mathrm{T}$ cell response to cytomegalovirus. J Immunol. 2001;167:1151-1163.

(4) Bitmansour AD, Douek DC, Maino VC, Picker LJ. Direct ex vivo analysis of human $\mathrm{CD} 4(+)$ memory $\mathrm{T}$ cell activation requirements at the single clonotype level. J Immunol. 2002;169:1207-1218.

(5) Khan N, Shariff N, Cobbold M et al. Cytomegalovirus seropositivity drives the CD8 T cell repertoire toward greater clonality in healthy elderly individuals. J Immunol. 2002;169:1984-1992.

(6) Vargas AL, Lechner F, Kantzanou M, Phillips RE, Klenerman P. Ex vivo analysis of phenotype and TCR usage in relation to CD45 isoform expression on cytomegalovirus-specific CD8+ $T$ lymphocytes. Clin Exp Immunol. 2001;125:432-439.

(7) Elkington R, Khanna R. Cross-recognition of human alloantigen by cytomegalovirus glycoprotein-specific CD4+ cytotoxic $\mathrm{T}$ lymphocytes: implications for graft-versus-host disease. Blood. 2005;105:1362-1364.

(8) Larsson K, Aschan J, Remberger $\mathrm{M}$ et al. Reduced risk for extensive chronic graft-versus-host disease in patients receiving transplants with human leukocyte antigen-identical sibling donors given polymerase chain reactionbased preemptive therapy against cytomegalovirus. Transplantation. 2004;77:526-531. 
(9) Vassallo C, Brazzelli V, Alessandrino PE et al. Normal-looking skin in oncohaematological patients after allogenic bone marrow transplantation is not normal. Br J Dermatol. 2004;151:579-586.

(10) Ferrara JL, Deeg HJ. Graft-versus-host disease. N Engl J Med. 1991;324:667674.

(11) Don RH, Cox PT, Wainwright BJ, Baker K, Mattick JS. 'Touchdown' PCR to circumvent spurious priming during gene amplification. Nucleic Acids Res. 1991;19:4008.

(12) Akatsuka Y, Cerveny C, Hansen JA. T cell receptor clonal diversity following allogeneic marrow grafting. Hum Immunol. 1996;48:125-134.

(13) Dietrich PY, Caignard A, Diu A et al. Analysis of T-cell receptor variability in transplanted patients with acute graft-versus-host disease. Blood. 1992;80:2419-2424.

(14) Hirokawa $M$, Matsutani $T$, Saitoh $H$ et al. Distinct TCRAV and TCRBV repertoire and CDR3 sequence of T lymphocytes clonally expanded in blood and GVHD lesions after human allogeneic bone marrow transplantation. Bone Marrow Transplant. 2002;30:915-923.

(15) Kubo K, Yamanaka K, Kiyoi $\mathrm{H}$ et al. Different T-cell receptor repertoires between lesions and peripheral blood in acute graft-versus-host disease after allogeneic bone marrow transplantation. Blood. 1996;87:3019-3026.

(16) Margolis DA, Casper JT, Segura AD et al. Infiltrating T cells during liver graftversus-host disease show a restricted T-cell repertoire. Biol Blood Marrow Transplant. 2000;6:408-415.

(17) Yamanaka K, Kwok WW, Mickelson EM et al. Selective T-cell-receptor gene usage in allorecognition and graft-versus-host disease. Transplantation. 1993;55:1167-1175. 
(18) Labalette M, Salez F, Pruvot FR, Noel C, Dessaint JP. CD8 lymphocytosis in primary cytomegalovirus (CMV) infection of allograft recipients: expansion of an uncommon CD8+. Clin Exp Immunol. 1994;95:465-471.

(19) Dietrich PY, Caignard A, Lim A et al. In vivo T-cell clonal amplification at time of acute graft-versus-host disease. Blood. 1994;84:2815-2820.

(20) Epperson DE, Margolis DA, McOlash L, Janczak T, Barrett AJ. In vitro T-cell receptor $\mathrm{V}$ beta repertoire analysis may identify which $T$-cell $\mathrm{V}$ beta families mediate graft-versus-leukaemia and graft-versus-host responses after human leucocyte antigen-matched sibling stem cell transplantation. $\mathrm{Br} \mathrm{J}$ Haematol. 2001;114:57-62.

(21) Liu X, Chesnokova V, Forman SJ, Diamond DJ. Molecular analysis of T-cell receptor repertoire in bone marrow transplant recipients: evidence for oligoclonal T-cell expansion in graft-versus-host disease lesions. Blood. 1996;87:3032-3044.

(22) Michalek J, Collins RH, Durrani HP et al. Definitive separation of graft-versusleukemia- and graft-versus-host-specific CD4+ T cells by virtue of their receptor beta loci sequences. Proc Natl Acad Sci U S A. 2003;100:1180-1184.

(23) Nikaein A, Poole T, Fishbeck R et al. Characterization of skin-infiltrating cells during acute graft-versus-host disease following bone marrow transplantation using unrelated marrow donors. Hum Immunol. 1994;40:68-76.

(24) Tsutsumi Y, Tanaka J, Miura $Y$ et al. Molecular analysis of T-cell repertoire in patients with graft-versus-host disease after allogeneic stem cell transplantation. Leuk Lymphoma. 2004;45:481-488.

(25) Wang L, Tadokoro K, Tokunaga $\mathrm{K}$ et al. Restricted use of T-cell receptor $\mathrm{V}$ beta genes in posttransfusion graft-versus-host disease. Transfusion. 1997;37:11841191. 


\section{CHAPTER 4}

\section{ENGRAFTMENT OF T CELL RECEPTOR (TCR) REPERTOIRE IN MYELOABLATED ALLOGENEIC HEMATOPOIETIC STEM CELL RECIPIENTS MIMICS DONOR TCR REPERTOIRE.}




\begin{abstract}
Hematopoietic stem cell (HSC) transplantation is used to rescue the immune system in patients who have received myeloblative regimens targeted at eradication of various hematological malignancies. In allogeneic HSC transplantation, stem cells from a healthy donor are infused into the recipient with the intent of reconstituting the recipient's immune system. Using the most comprehensive set of TCRBV primers available, we determined through real time RT-PCR that the reconstitution of the recipient's $\mathrm{T}$ cell repertoire post- hematopoietic stem cell transplant was of a higher correlation to that found in the donor compared to that found in the recipient prior to transplant. Our results argue that, despite the influence of the recipient's environment, the donor stem cells mature in the recipient's body with a TCRBV repertoire reminiscent of that found in the donor.
\end{abstract}

\title{
INTRODUCTION
}

The major goal of allogeneic hematopoietic stem cell transplantation is to achieve complete engraftment of healthy donor hematopoietic stem cells and subsequent immune reconstitution within the new environment of the recipient. T cells are a critical component of the recipient's defense system against invading pathogens and the reactivation of latent infections through the recognition of antigen through the $\mathrm{T}$ cell receptor (TCR). While T cells play a critical role in the immune system's defenses, it is not known whether the maturing $\mathrm{T}$ cells found in the recipient display a $\mathrm{T}$ cell receptor beta variable (TCRBV) repertoire more like that in the donor or if they exhibit a repertoire more reminiscent of that found in the recipient prior to transplant. In this study, we used real-time RT-PCR and a comprehensive panel of primers, developed in response to the reclassification of the TCR genes ${ }^{1}$, to monitor the profile of the engrafting TCRBV regions. In the first 100 days after transplant, despite the influence of the recipient's HSC environment on the development of the immature cells ${ }^{2-4}$, the T cell repertoire appears to develop with a phenotype more reminiscent of that found in the donor as opposed to that found in the recipient prior to transplant. 


\section{MATERIALS AND METHODS}

\section{Patient population}

Study subjects $(n=4)$ were patients undergoing transplant treatment at West Virginia University's Blood and Marrow Transplant and Hematological Malignancy Program, Morgantown, West Virginia. Informed consent was obtained from participants after the nature and possible consequences of the study had been fully explained according to West Virginia University's Institutional Review Board guidelines. All study patients received hematopoietic stem cells collected from the peripheral blood of mobilized donors who had been primed with G-CSF. The donors were serologically HLA matched to the recipient at a minimum of HLA-A, B, and DR loci. Prior to peripheral blood stem cell (PBSC) infusion, study recipients underwent myeloblative conditioning regimens consisting of either Thiotepa (500 mg/m² $\mathrm{q} 12 \mathrm{~h} \times 2$ doses), Campath-1H (20mg $\times 2$ doses), and total body irradiation (TBI) (1000 cGy total dose: given in 200cGy fractions) or Busulfan (1mg/kg p.o. q6h x 16 doses) and Cytoxan (60 mg/kg/d x 2 doses) (Table 1). Full supportive care, including GVHD prophylaxis, anti-fungal, antiviral, and anti-PCP prophylaxis, empiric anti-microbial therapy for neutropenic febrile episodes, and transfusions were provided per standard operating policies. Peripheral blood, $\sim 20 \mathrm{~mL}$, was collected weekly, via venipuncture from hematopoietic stem cell transplant patients, into an acid citrate dextrose VACUTAINER ${ }^{\text {TM }}$ blood collection tube (Becton Dickinson, Franklin Lakes, NJ, USA). Buffy coat layers were isolated via centrifugation at $3300 \mathrm{rcf}$ for 10 minutes. Contaminating red blood cells were removed by hypotonic lysis. 


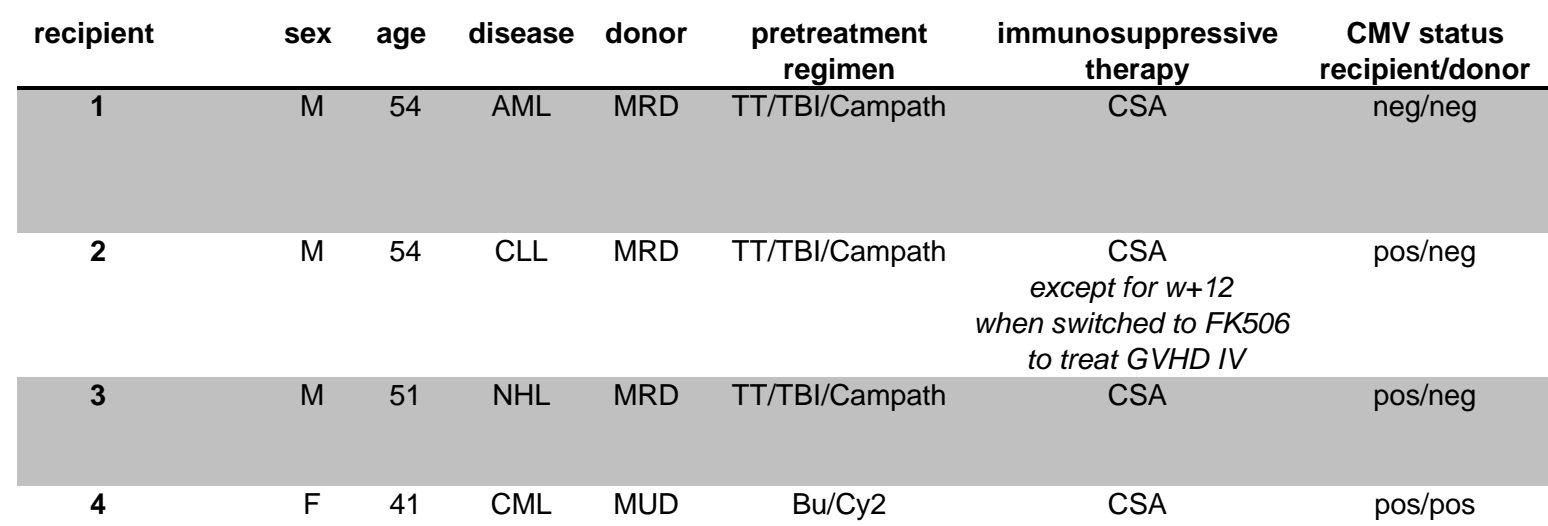

Table 1: Patient demographics

All patients received peripheral blood hematopoietic stem cell transplants from an HLA-matched related donor (MRD). HLA matching was performed serologically. Cytomegalovirus (CMV) status was determined in both recipient and donor prior to transplant by evaluating CMV IgG and IgM serum levels. Complications experienced in the recipient post transplant, as determined by standard clinical evaluation, are indicated on the far right side of the table. All patients were living at the conclusion of our study. Abbreviations: M, male; F, female; AML, acute myelogenous leukemia; CLL, chronic lymphocytic leukemia; NHL, non-Hodgkin lymphoma; CML, chronic myelogenous leukemia; TT, Thiotepa; TBI, total body irradiation; Bu, Busulfan; Cy2, Cytoxan; GVHD, graft-versus-host disease.

\section{RNA Isolation}

Total RNA was isolated from $20-40 \times 10^{6}$ white blood cells using TRIzol ${ }^{\circledR}$ Reagent as previously described (Brewer and Ericson, J. of Immunol. Methods, in press). RNA was dissolved in ultra-PURE ${ }^{\mathrm{TM}}$ Distilled DNAse and RNAse free water (Invitrogen Corporation, Carlsbad, CA, USA). DNase treatment was performed on isolated RNA according to the manufacturer's recommendations using DNA-free ${ }^{\mathrm{TM}}$ (Ambion, Austin, TX, USA). RNA purity and concentration was determined by standard $260 \mathrm{~nm}: 280 \mathrm{~nm}$ spectrophotometric analysis using a Genesis 10UV Spectronic Unicam (Spectronic Instruments, Rochester, NY, USA). 


\section{$R T-P C R$}

One Step RT-PCR was performed using the QuantiTect ${ }^{\mathrm{TM}}$ Probe RT-PCR kit (Qiagen, Valencia, CA, USA) with sequence specific detection as previously described (Brewer and Ericson, J. of Immunol. Methods, in press).

\section{Statistical Analyses}

Spearman rank correlation coefficient analysis was used to determine the correlation of the TCRBV engraftment phenotypes.

\section{RESULTS AND DISCUSSION}

The TCRBV repertoire engrafts with a phenotype similar to that present in the donor.

By analyzing the expression of all of the TCRBV families in the donor and recipient pre-transplant followed by weekly analysis of these families in the recipient post transplant, we could monitor the TCRBV phenotype of the recipient's engrafted cells during the early reconstitution period (Table 2). While neutrophil engraftment begins one to two weeks after transplant, complete restoration of the $\mathrm{CD}^{+}$population typically requires many months post-transplant ${ }^{5}$. We compared correlation parameters at weekly intervals and here report the correlation seen at baseline and at day 100 . The day 100 TCRBV expression patterns obtained from patients 1, 2, and 3 showed a stronger correlation to the baseline donor TCRBV expression profile compared to the recipient's baseline TCRBV repertoires (sample 1: -0.193 vs. 0.68, sample 2: 0.330 vs. 0.510, sample 3: 0.329 vs. 0.664). At the conclusion of this study, there was a decreased correlation of recipient samples to their own pre-transplant TCRBV profile when compared to the donor's baseline TCRBV expression profile (sample 1: -0.219 vs. 0.68 , sample 2: 0.289 vs. 0.510 , sample 3: 0.537 vs. 0.664$)$. These results were compared to the correlation of the TCRBV repertoire found in healthy peripheral blood donors over a period of two weeks, which exhibited a correlation to self of $\sim 0.75$ (Table 2). 


\begin{tabular}{lcccc} 
sample & $\begin{array}{c}\text { correlation to self } \\
\mathbf{t}=\mathbf{0} \text { (baseline) }\end{array}$ & $\begin{array}{c}\text { correlation to donor } \\
\mathbf{t}=\mathbf{0} \text { (baseline) }\end{array}$ & $\begin{array}{c}\text { correlation to self } \\
\mathbf{t}=\mathbf{d}+\mathbf{1 0 0}\end{array}$ & $\begin{array}{c}\text { correlation to donor } \\
\mathbf{t}=\mathbf{d}+\mathbf{1 0 0}\end{array}$ \\
\hline recipient 1 & 1 & -0.192820513 & -0.218803419 & 0.68 \\
recipient 2 & 1 & 0.33025641 & 0.289230769 & 0.51042735 \\
recipient 3 & 1 & 0.329230769 & 0.536752137 & 0.663931624 \\
recipient 4 & 1 & 0.517264957 & 0.361367521 & 0.246495726
\end{tabular}

\begin{tabular}{ccc}
$\begin{array}{c}\text { healthy volunteer } \\
\text { donors }\end{array}$ & $\begin{array}{c}\text { correlation to self } \\
\mathbf{t = 0} \text { (baseline) }\end{array}$ & $\begin{array}{c}\text { correlation to self } \\
\mathbf{t = + 2} \text { weeks }\end{array}$ \\
\hline donor $\mathbf{1}$ & 1 & 0.748462 \\
donor $\mathbf{2}$ & 1 & 0.756154 \\
donor $\mathbf{3}$ & 1 & 0.789231 \\
donor $\mathbf{4}$ & 1 & 0.742692
\end{tabular}

Table 2: The TCRBV repertoire engrafts with a phenotype similar to that present in the donor.

Spearman rank correlation coefficients were determined for the TCRBV repertoire expression in both recipient and donor prior to transplant (baseline) and at the conclusion of the study (day +100). A correlation coefficient of one represents a perfect correlation. All recipients, with the exception of recipient 4 , had a greater correlation to the donor than to themselves at day +100 . This is compared in the context of the TCRBV repertoire observed in healthy individuals over a two-week period.

With a single exception, recipient 4, we observed the engraftment of a $\mathrm{T}$ cell receptor phenotype with greater correlation to baseline profiles found in the donors, as opposed to those found in the recipients, prior to transplant. Recipient number 4 was the only patient in our study who received a different pre-conditioning regimen, Cytoxan and Busulfan, compared to the TT/TBI/Campath- $1 \mathrm{H}$ regimen. One possible explanation for this difference is the highly T-cell suppressive effect observed in patients who receive a preparative regimen containing Campath-1H (anti-CD52), an agents whose effects linger due to its persistence in patient serum several weeks after its final administration. 
All patients were determined to be $100 \%$ donor engrafted at day 30 posttransplant, with the exception of recipient 4 , whose chimerism analysis was not performed until day 100 post transplant, at which point chimerism was also determined to be $100 \%$ donor in origin. While these results are preliminary, they suggest that the developing TCRBV repertoire in the recipient is more closely reflecting that found in the donor as opposed to that found in the recipient prior to transplant. It is unlikely that these results are attributable to mature donor $T$ cells found within the graft as recipients received Campath therapy (anti-CD52), which targets $T$ cells for antibody dependent lysis ${ }^{6}$ and samples also exhibited the formation of TRECs.

\section{REFERENCE LIST}

(1) Arden B, Clark SP, Kabelitz D, Mak TW. Human T-cell receptor variable gene segment families. Immunogenetics. 1995;42:455-500.

(2) Bevan MJ. In a radiation chimaera, host $\mathrm{H}-2$ antigens determine immune responsiveness of donor cytotoxic cells. Nature. 1977;269:417-418.

(3) Fink PJ, Bevan MJ. H-2 antigens of the thymus determine lymphocyte specificity. J Exp Med. 1978;148:766-775.

(4) Zinkernagel RM, Callahan GN, Klein J, Dennert G. Cytotoxic T cells learn specificity for self $\mathrm{H}-2$ during differentiation in the thymus. Nature. 1978;271:251253.

(5) Small TN, Papadopoulos EB, Boulad F et al. Comparison of immune reconstitution after unrelated and related T-cell-depleted bone marrow transplantation: effect of patient age and donor leukocyte infusions. Blood. 1999;93:467-480.

(6) Dumont FJ. CAMPATH (alemtuzumab) for the treatment of chronic lymphocytic leukemia and beyond. Expert Rev Anticancer Ther. 2002;2:23-35. 


\section{CHAPTER 5}

CYCLOSPORINE A (CSA) AND TACROLIMUS (FK506)

DIFFERENTIALLY ALTER T CELL RECEPTOR (TCR) EXPRESSION

IN VIVO. 


\begin{abstract}
Cyclosporin A (CSA) and tacrolimus (FK506) are two common immunosuppressive agents used post blood and marrow transplantation. They exert their effects through the inhibition of calcineurin activity and subsequent inhibition of IL-2 production. IL-2 is a cytokine needed for proliferation of activated T cells, an immune cell commonly responsible for post transplant complications such as graft rejection and graft-versus-host disease. Despite similarity in their mode of action, we observed polarized effects of CSA and FK506 on the human T cell repertoire, as monitored through the expression of the $\mathrm{T}$ cell receptor beta variable (TCRBV) regions. To determine the possible mechanism for this difference, in vitro experiments using the Jurkat human T-cell line were performed. The effects of CSA and FK506 on cell viability, cell proliferation, IL-2 production, and calcineurin inhibition were determined and no significant differences between the two agents were observed. The data suggest that a secondary mechanism of action exists for the different TCRBV repertoire induced by exposure to CSA and FK506.
\end{abstract}




\section{INTRODUCTION}

Immunosuppressive agents are widely used in the treatment of various medical conditions, in particular for allogeneic blood and marrow transplantation (BMT). Post transplant recipients are at a significant risk of rejecting their graft or developing a condition known as graft-versus-host disease (GVHD). T lymphocytes are known to be the primary immune mediators of such reactions ${ }^{1,1-5}$. Cyclosporin $A$ (CSA) and tacrolimus (FK506) are two commonly employed agents used to prevent allograft rejection and to decrease the risk of developing GVHD in the BMT setting ${ }^{6}$.

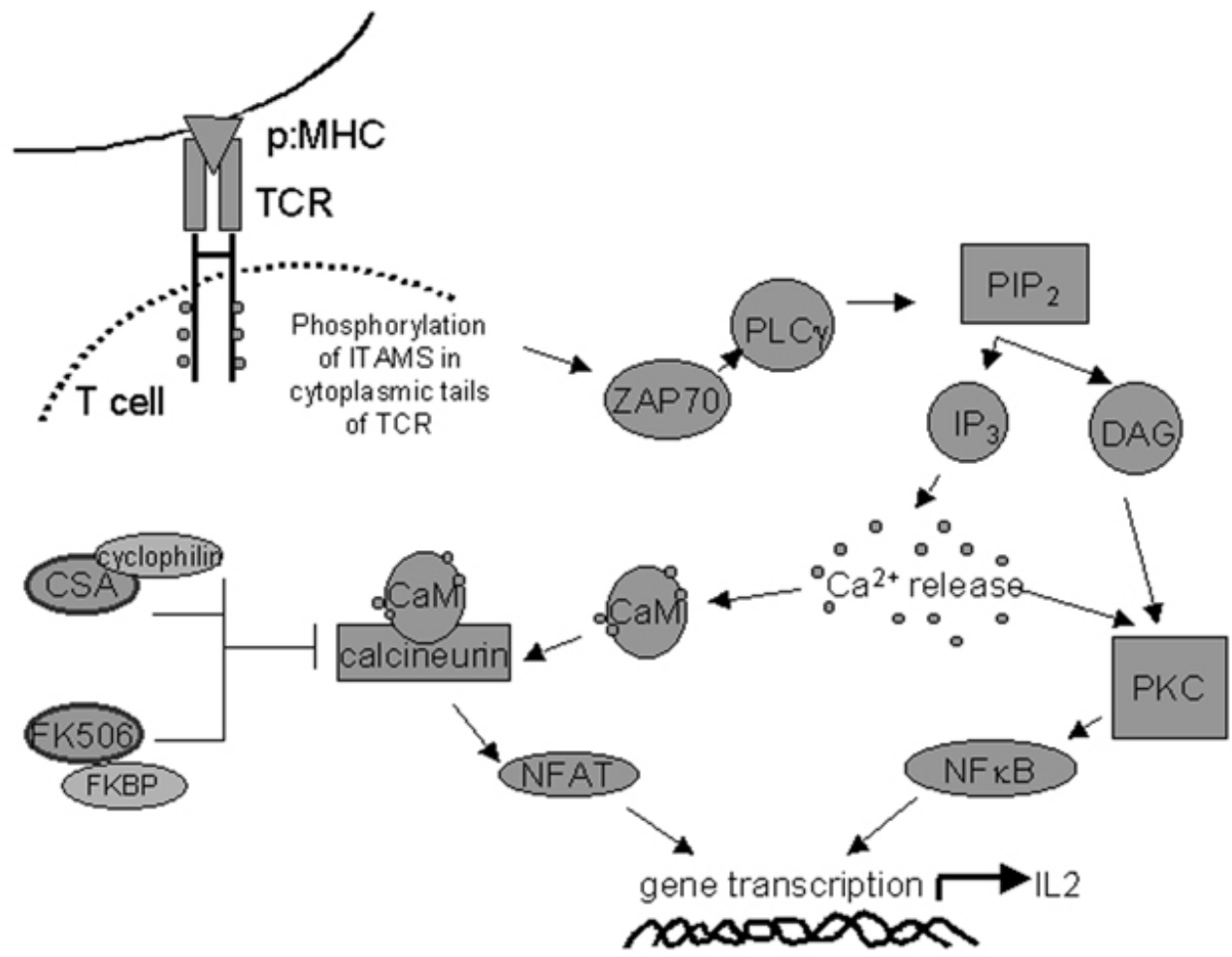

Figure 1: Abbreviated schematic of the signaling pathway activated by engagement of the $T$ cell receptor (TCR) and its inhibition by CSA and FK506.

Abbreviations: p:MHC, peptide:major histocompatibility complex; TCR, $T$ cell receptor; ITAMS, immunoreceptor tyrosine-based activation motifs; PLC, phospholipase C; PIP-2, phosphatidylinositol biphosphate; $I P_{3}$, inositol triphosphate; DAG, diacylglycerol; $\mathrm{Ca}^{2+}$, calcium; CaM, calmodulin; PKC, protein kinase C; CSA, cyclosporin A; FKBP, FK-binding protein; NFAT, nuclear factor of activated $T$ cells; $N F K B$, nuclear factor $K B$; IL2, interleukin 2. 
The overall effect of CSA and FK506 is to impair the production of interleukin 2 (IL-2) by T lymphocytes. This is accomplished through the binding of CSA and FK506 to cyclophilin ${ }^{7,8}$ and FK506-binding proteins ${ }^{9-12}$, respectively. This binding causes the subsequent inhibition of the protein calcineurin, a protein critical to the production of IL2 (Figure 1) ${ }^{13-16}$. IL-2 is produced primarily by activated T cells and is required for $\mathrm{T}$ cell proliferation ${ }^{17}$. Since extensive similarities (including mechanism of action and agent entry into cells) exist between CSA and its derivative, FK506 ${ }^{18}$, suppression of the T lymphocyte response is expected to be comprehensive and similar between the two agents. However, we observed polarized effects of CSA and FK506 on the T cell repertoire, as monitored through $\mathrm{T}$ cell receptor beta variable region (TCRBV) expression patterns. FK506 suppressed the expression of the majority of TCRBV families while an increased expression in specific TCRBV families was observed with CSA. Cell viability, proliferation, IL-2 production, and calcineurin activity in response to CSA and FK506 treatments were measured in vitro using the Jurkat human T-cell line. In addition to their extensive usage as an in vitro human T cell model, Jurkat cells were selected based upon their expression of TCRBV8 ${ }^{19}$, a TCR that showed varied responses to CSA and FK506 in our experiments. The experiments were designed to determine the potential mechanistic difference that could be responsible for the differing TCRBV expression pattern observed in vivo. 


\section{MATERIALS AND METHODS}

\section{Human Subjects}

Study subjects $(n=5)$ were patients who underwent allogeneic peripheral blood stem cell transplants at West Virginia University's Mary Babb Randolph Cancer Center, Morgantown, West Virginia. Informed consent was obtained from participants after the nature and possible consequences of the study had been fully explained according to West Virginia University's Internal Review Board guidelines. A volume of $\sim 20 \mathrm{~mL}$ peripheral blood was collected weekly through day 100 post transplant, via venipuncture from hematopoietic stem cell transplant patients, into an acid citrate dextrose VACUTAINER ${ }^{\mathrm{TM}}$ blood collection tube (Becton Dickinson, Franklin Lakes, NJ, USA). Buffy coat layers were isolated via centrifugation at $3300 \mathrm{rcf}$ for 10 minutes. Contaminating red blood cells were removed by hypotonic lysis.

\section{Cell Lines}

In vitro experiments were performed using the Jurkat human T-cell line (clone E6-1) (American Type Culture Collection, Rockville, MD). Cells were cultured at a density of $4 \times 10^{5}$ cells $/ \mathrm{mL}$ in RPMI-1640 (HyClone, Logan, UT) supplemented with $10 \%$ heat-inactivated fetal calf serum (FCS) (Hyclone), $2 \mathrm{mM}$ L-glutamine (BioWhittaker, Walkersville, MD), penicillin (100U/mL) (BioWhittaker), streptomycin (100ug/mL) (BioWhittaker), and 2-mercaptoethanol (0.049 mM) (Sigma Chemical Co., St. Louis, $\mathrm{MO})$, and $50 \mathrm{mM}$ Hepes (BioWhittaker).

\section{Treatments}

For human studies, patients were treated with CSA and/or FK506 according to established treatment protocols at the West Virginia University Mary Babb Randolph Cancer Center's Blood and Marrow Transplant Program. CSA therapy is classically utilized when the recipient has a matched related donor (MRD) and FK506 therapy is instituted when the recipient has a matched unrelated donor (MUD) or is unresponsive post-transplant to CSA therapy. CSA and/or FK506 treatment started one day before transplant ( $d-1)$ and continued throughout the study period. Patients were monitored biweekly for CSA and FK506 serum concentrations. Patient dosages were adjusted, as 
necessary, to be within the preferred protocol serum concentrations of $200+/-20 \mathrm{ng} / \mathrm{mL}$ for CSA and 7-12 ng/mL for FK506.

For in vitro cell culture studies, CSA (Bedford Laboratories, Bedford, $\mathrm{OH}$ ) and FK506 (Fujisawa Healthcare, Inc., Deerfield, IL) were diluted in prepared media (previously described) to obtain $1 / 2 x, 1 x$, and $2 x$ of the target therapeutic dose. This resulted in the following concentrations: for CSA, $100 \mathrm{ng} / \mathrm{mL}, 200 \mathrm{ng} / \mathrm{mL}$, and $400 \mathrm{ng} / \mathrm{mL}$; for FK506, $5 \mathrm{ng} / \mathrm{mL}, 10 \mathrm{ng} / \mathrm{mL}$, and $20 \mathrm{ng} / \mathrm{mL}$. Cells were pretreated $+/$ - CSA or FK506 for 30 minutes at $37^{\circ} \mathrm{C}$ followed by addition of the stimulating agents phorbol 12-myristate acetate (PMA) (Sigma Chemical Co.) and A23187 calcium ionophore (Sigma Chemical Co.) at $10 \mathrm{ng} / \mathrm{mL}$ and $1 \mathrm{ug} / \mathrm{mL}$, respectively.

\section{RNA Isolation}

Total RNA was isolated from 20-40 x $10^{6}$ white blood cells using TRIzol ${ }^{\circledR}$ Reagent according to the manufacturer's directions (Ambion, Austin, TX, USA). RNA was dissolved in ultra-PURE ${ }^{\mathrm{TM}}$ Distilled DNAse and RNAse free water (Invitrogen Corporation, Carlsbad, CA, USA). DNase treatment was performed on isolated RNA according to the manufacturer's recommendations using DNA-free ${ }^{\text {TM }}$ (Ambion). RNA purity and concentration was determined by standard $260 \mathrm{~nm}: 280 \mathrm{~nm}$ spectrophotometric analysis using a Genesis 10UV Spectronic Unicam (Spectronic Instruments, Rochester, NY, USA).

\section{$R T-P C R$}

One Step RT-PCR was performed using the QuantiTect ${ }^{\mathrm{TM}}$ Probe RT-PCR kit (Qiagen, Valencia, CA, USA). Recommended reaction mixtures were scaled down to a total reaction volume of $20 \mu \mathrm{L}$ using $0.04 \mu \mathrm{g}$ RNA with the following primer and probe concentrations: $0.4 \mu \mathrm{M}$ TCRBV primer (Biosource International, Camarillo, CA, USA), $0.4 \mu \mathrm{M}$ TCRBC primer (Biosource International), and $0.2 \mu \mathrm{M}$ TCRBC TaqMan ${ }^{\circledR}$ probe, 5 ' 6-FAM, 3' BHQ ${ }^{\mathrm{TM}}$-1 (Integrated DNA Technologies, Inc., Coralville, IA, USA). The method, including primer and probe sequences, was as previously described (Brewer and Ericson, J. Immunol. Method, in press). In brief, 18SrRNA standardization reactions were performed in parallel using $0.4 \mu \mathrm{M}$ each of sense and anti-sense primers 
(Biosource International) and $0.2 \mu \mathrm{M}$ 18S rRNA TaqMan® probe, 5' 6-FAM, 3' BHQ ${ }^{\mathrm{TM}}$ 1 (Integrated DNA Technologies, Inc.). An iCycler' (BioRad Laboratories, Hercules, CA, USA) was used for the RT and amplification cycles. RT was performed at $50^{\circ} \mathrm{C}$ for 60 minutes, max ramp speed, followed by an initial Taq activation step of 15 minutes at $95^{\circ} \mathrm{C}$, max ramp speed. A TouchDown PCR approach ${ }^{20}$ was used with the following cycling conditions: denaturation for 15 seconds at $95^{\circ} \mathrm{C}$, max ramp speed, annealing for 30 seconds starting at $70^{\circ} \mathrm{C}$ decreasing by $2^{\circ} \mathrm{C}$ for 10 repeats, max ramp speed, and extension for 40 seconds at $72^{\circ} \mathrm{C}$, min ramp speed. After this TouchDown of the annealing temperature, 50 cycles were performed as follows with the optical data collection occurring at the extension step: 15 seconds at $95^{\circ} \mathrm{C}$ (max ramp speed), 30 seconds at $52^{\circ} \mathrm{C}$ ( $\max$ ramp speed), and 40 seconds at $60^{\circ} \mathrm{C}$ (min ramp speed). Reactions were held at $4^{\circ} \mathrm{C}$ upon the conclusion of the run. Cycle threshold (Ct) values, or the cycle at which fluorescent amplification readings exceed background level, were determined using iCycler ${ }^{\mathrm{TM}}$ iQ Optical System Software Version 3.0a (BioRad Laboratories, Hercules, CA, USA). The primer sets utilized in this study have been previously shown to yield $\mathrm{Ct}$ values that are directly proportional to the amount of template present in the initial reactions (Brewer and Ericson, J. Immunol. Method, in press).

\section{Viability assay}

$3 \times 10^{6}$ Jurkat cells (at a density of $4 \times 10^{5}$ cells $/ \mathrm{mL}$ ) were plated per treatment condition. At time points 24 hours, 36 hours, and 48 hours, $1 \times 10^{6}$ cells were removed from the culture. Viability was determined by trypan blue exclusion (Gibco Laboratories, Grand Island, NY) and 7-AAD incorporation (BD Pharmingen, San Diego, CA). 7-AAD incorporation was performed according to the manufacturer's instructions. Stained cells were resuspended in $200 \mu \mathrm{L} 1 \%$ paraformaldehyde solution. 30,000 total events were collected per sample using a Becton Dickinson FACSCalibur ${ }^{\mathrm{TM}}$ that was calibrated using Calibrite Beads ${ }^{\mathrm{TM}}$ and FACSCOMPTM software (Becton Dickinson, Franklin Lakes, NJ). Acquisition of data was performed using CellQuest ${ }^{\mathrm{TM}}$ Pro software (Becton Dickinson). Data was analyzed using Windows Multiple Document Interface (WinMDI) version 2.8 
(Joseph Trotter, The Scripps Research Institute, http://facs.scripps.edu/software.html [14 December 2001]).

\section{Cell proliferation assay}

Cell proliferation was monitored by labeling cells prior to culture using the Molecular Probes Vybrant ${ }^{\mathrm{TM}}$ CFDA SE Cell Tracer Kit (Molecular Probes, Inc., Eugene, OR) according to manufacturer's instructions. $3 \times 10^{6}$ CFSE labeled Jurkat cells (at a density of $4 \times 10^{5}$ cells $/ \mathrm{mL}$ ) were plated per treatment condition. At time points, 24 hours, 36 hours, and 48 hours, $1 \times 10^{6}$ cells were removed from the culture, spun down and washed in 1x PBS prior to being resuspend in 200uL 1\% paraformaldehyde. Cells were analyzed using a Becton Dickinson FACSCalibur ${ }^{\mathrm{TM}}$ that was calibrated using Calibrite Beads $^{\mathrm{TM}}$ and FACSCOMPTM software (Becton Dickinson). Acquisition of data was performed using CellQuest ${ }^{\mathrm{TM}}$ Pro software (Becton Dickinson). Results were analyzed using ModFit LT ${ }^{\mathrm{TM}}$ software (Verity Software House, Topsham, ME). A total of 30,000 events were collected and analyzed per sample.

\section{IL-2 production}

$3 \times 10^{6}$ Jurkat cells (at a density of $4 \times 10^{5}$ cells $/ \mathrm{mL}$ ) were plated per treatment condition. At time points, 24 hours, 36 hours, and 48 hours, $1 \times 10^{6}$ cells were removed from the culture and spun down. Supernatant was harvested and used to determine IL-2 production using the BD OptEIA ${ }^{\text {TM }}$ Human IL-2 ELISA Kit II (BD Biosciences, San Diego, CA) according to manufacturer's instructions. Colorimetric reactions were read on a Labsystems Multiskan MCC/340 microplate reader (Molecular Devices Corporation, Sunnyvale, CA) and data was analyzed using the Genesis Lite Version 3.0 software (Life Sciences International Ltd., Basingstoke, UK).

\section{Calcineurin Activity}

The Calcineurin Cellular Activity Assay Kit (Calbiochem, San Diego, CA) was used to determine the activity of calcineurin under various treatment condition. $4.5 \times 10^{6}$ Jurkat cells (at a density of $4 \times 10^{5}$ cells $/ \mathrm{mL}$ ) were pretreated with doses of CSA or 
FK506 for 30 minutes at $37^{\circ} \mathrm{C}$ followed by stimulation with PMA and A23187 (as described above) for 0 minutes, 5 minutes, 10 minutes, 20 minutes, or 30 minutes. Cells were harvested, washed, and lysed according to kit instructions. The harvested "high speed supernatant" was desalted using Econo-Pac ${ }^{\circledR}$ 10DG Columns (Bio-Rad Laboratories). Trace contaminating salts were determined to be absent from the desalted samples using the GREEN ${ }^{\mathrm{TM}}$ reagent as described in the assay kit. Desalted "high speed supernatants" were assayed for calcineurin phosphatase activity as described by the manufacturer's instructions. Colorimetric reactions were read on a Labsystems Multiskan MCC/340 microplate reader (Molecular Devices Corporation) and data was analyzed using the Genesis Lite Version 3.0 software (Life Sciences International Ltd.).

\section{Statistical Analyses}

For TCRBV alterations in response to CSA and FK506, bivariate fit statistical analysis was employed. One-way analysis of variance with Tukey's post-hoc test was performed for all other statistical analyses. 


\section{RESULTS}

\section{Cyclosporin A and FK506 differentially impact T cells bearing specific $T$ cell receptors.}

In order to assess any alterations in the T cell receptor beta variable (TCRBV) repertoire associated with the administration of cyclosporin A (CSA) or

\begin{tabular}{|c|c|c|c|c|c|}
\hline TCRBV & $\begin{array}{l}\text { TCRBV expression } \\
\text { change in response to } \\
\text { increased [FK506] }\end{array}$ & $p$ value & TCRBV & $\begin{array}{l}\text { TCRBV expression } \\
\text { change in response to } \\
\text { increased [CSA] }\end{array}$ & $p$ value \\
\hline 1 & $\downarrow$ & 0.0107 & 4 & $\uparrow$ & 0.0199 \\
\hline 2 & $\downarrow$ & 0.0053 & 5 & $\uparrow$ & 0.0157 \\
\hline 3 & $\downarrow$ & 0.0221 & $6.1,3,4,6,8$ & $\uparrow$ & 0.0102 \\
\hline 4 & $\downarrow$ & 0.0002 & 8 & $\downarrow$ & 0.0481 \\
\hline 5 & $\downarrow$ & 0.0117 & 9 & $\downarrow$ & 0.0191 \\
\hline $6,1,3,4,6,8$ & $\downarrow$ & 0.0001 & 11 & $\uparrow$ & 0.0002 \\
\hline 11 & $\downarrow$ & 000000 & 12.1 & $\uparrow$ & 0.0011 \\
\hline & & 0.0000 & $13.1-4,6,6.7$ & $\uparrow$ & 0.0018 \\
\hline 12.1 & $\downarrow$ & 0.0000 & 15 & $\uparrow$ & 0.0009 \\
\hline 12.2 .3 & $\downarrow$ & 0.0003 & 16 & $\uparrow$ & 0.0260 \\
\hline $13.1-4, .6,7$ & $\downarrow$ & 0.0000 & 21 & $\uparrow$ & 0.0337 \\
\hline 13.5 & $\downarrow$ & 0.0000 & 24 & $\downarrow$ & 0.0032 \\
\hline 14 & $\downarrow$ & 0.0004 & 25 & $\downarrow$ & 0.0066 \\
\hline 15 & $\downarrow$ & 0.0000 & & & \\
\hline 16 & $\downarrow$ & 0.0000 & & & \\
\hline 20 & $\downarrow$ & 0.0009 & & & \\
\hline 21 & $\downarrow$ & 0.0000 & & & \\
\hline 22 & $\downarrow$ & 0.0100 & & & \\
\hline 23 & $\downarrow$ & 0.0065 & & & \\
\hline 24 & $\uparrow$ & 0.0242 & & & \\
\hline
\end{tabular}

Table 1: In vivo TCRBV expression changes in response to increases in FK506 and CSA dosages.

Opposite trends were observed for the changes in TCRBV repertoire expression in response to the immunosuppressive agents FK506 and CSA. Results shown are derived from analysis of 5 patients, 11-14 time points/patient totaling 70 separate observations, each performed in triplicate. Reported $p$-values are indicative of statistical significance with a confidence interval of at least $95 \%$, or $p<0.05$.

tacrolimus (FK506), human $\mathrm{T}$ cells were isolated from allogeneic peripheral (hematopoietic) stem cell transplant patients weekly up to 100 days post transplant. We hypothesized that both CSA and FK506 would have a "global" immunosuppressive 
effect on the T cells within the hematopoietic stem cell recipients. Analysis of the TCRBV repertoire, however, demonstrated polarized responses of T cells to these two agents (Table 1). When TCRBV expression was analyzed in response to FK506, a predominant suppression was observed in its effects on $T$ cells bearing specific receptors, specifically TCRBV1-6, 11-16, and 20-23. However, when samples were analyzed for the effect induced by CSA, an increase in the expression of TCRBV4-6, $11-13,15,16$, and 21 was observed. The in vivo concentration of CSA and FK506 can be impacted by various factors. Calcium channel blockers, anti-fungal agents, antibiotics, and anti-inflammatory drugs are among the agents known to potentially increase the serum concentrations of CSA and FK506 (according to manufacturer). Anticonvulsants, grapefruit, and dietary supplements, such as St. John's Wort, may have the opposite effect and decrease serum concentrations of CSA and FK506 (according to manufacturer). To ensure that such metabolic alterations were not causing artificial changes in the expression of the TCRBV repertoire, serum concentrations of CSA and FK506 were also analyzed for their impact on the TCRBV expression levels. The analyses using either the actual dosage level (Table 1) or the serum level (data not shown) yielded similar results.

\section{Cyclosporin A and FK506 affect on cell viability.}

It is possible that the different TCRBV usage between CSA and FK506 in vivo was due to a differential effect of the two agents on T cell viability. In order to assess

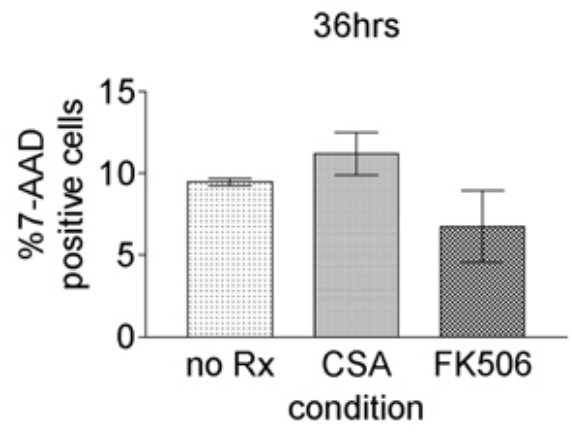

Figure 2: Effects of CSA and FK506 on Jurkat cell viability as measured by 7-AAD exclusion. this potential difference in viability in vitro studies were performed using the T-cell derived Jurkat cell line. Jurkat cells were pretreated with a range of concentrations of CSA $(0-400 \mathrm{ng} / \mathrm{mL})$ or FK506 (0-20ng/mL) prior to stimulation with PMA and A23187 and then cultured for $24 \mathrm{hr}, 36 \mathrm{hr}$, or 48 $\mathrm{hr}$ at which time 7-AAD staining was done to access viability. As depicted in Figure 2, significant differences were not obtained in cell viability, despite the presence of CSA or FK506. 
Similar results were seen when cells were pretreated with any of the following concentrations of immune suppressive agents: one-half therapeutic dose (CSA: 100ng/mL, FK506: $5 \mathrm{ng} / \mathrm{mL}$ ), therapeutic dose (CSA: $200 \mathrm{ng} / \mathrm{mL}$, FK506: $10 \mathrm{ng} / \mathrm{mL}$ ), or twice the therapeutic dose (CSA: $400 \mathrm{ng} / \mathrm{mL}$, FK506: $20 \mathrm{ng} / \mathrm{mL}$ ), or when viability was assessed after 24 hours or 48 hours of culture. At $24 \mathrm{hr}, 36 \mathrm{hr}$, and $48 \mathrm{hr}$, a trend of higher cell death was observed with the pretreatment of both the therapeutic and twice the therapeutic doses of CSA compared to FK506. These difference, however, were not found to be statistically significant. Similar results were also observed when viability was assessed by trypan blue exclusion.

\section{Treatment with Cyclosporin A and FK506 do not alter the proliferation of Jurkat cells.}

With viability not noticeably altered by treatment with either CSA or FK506, the proliferative ability of the treated cells was examined next.

\section{$48 \mathrm{hrs}$}

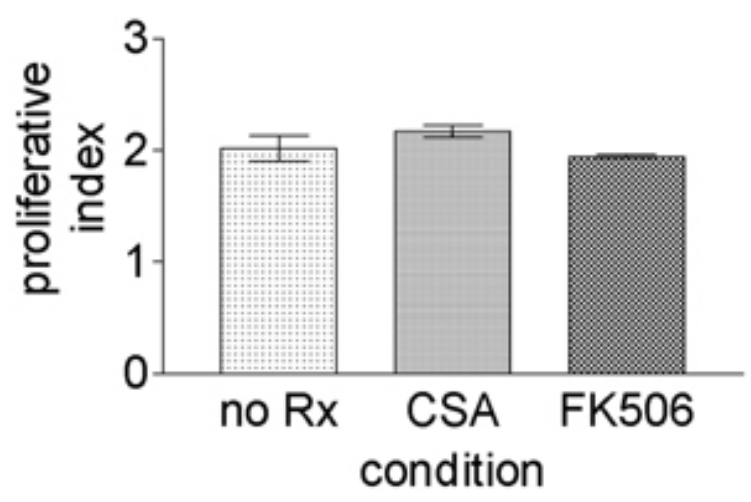

Figure 3: Effects of CSA and FK506 on Jurkat cell proliferation as determined by CFSE cellular membrane labeling.

The proliferative index, or the sum of the cells in all generations divided by the computed number of original parent cells present at the start of the experiment, was determined for all samples from two independent experiments with their means +/- SEM indicated. The proliferative index is a measure of the increase in cell number in the culture over the experimental period. No statistically significant differences were observed for proliferation experiments. Abbreviations: no $R x$, no addition of immunosuppressive agent; CSA, plus the addition of cyclosporin A; FK506, plus the addition of FK506. Experiments depicted are for target therapeutic doses of CSA (200ng/mL) and FK506 (10ng/mL). 
The proliferative index is a calculated measurement of the increase observed in the culture's cell number over the course of the experiment. As depicted in Figure 3, no statistically significant difference in cellular proliferation was observed when cells were treated with either CSA or FK506. Additionally, no statistically significant differences were detected when the cells were treated with a range of concentrations of CSA or FK506 (one-half therapeutic dose, therapeutic dose, or twice the therapeutic dose) or when cells were permitted to proliferate for 24,36 , or 48 hours.

\section{Cyclosporin A and FK506 inhibit IL-2 production in Jurkat cells.}

CSA and FK506 are known to inhibit IL-2 production by T cells ${ }^{13-16}$. While high

\section{$24 \mathrm{hrs}$}

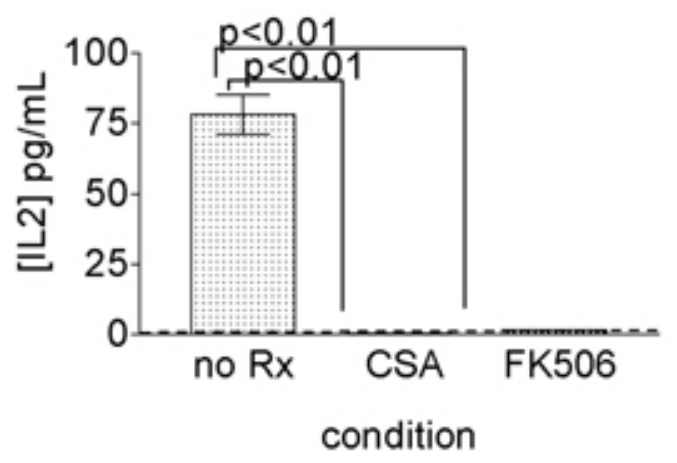

Figure 4: Effects of CSA and FK506 on IL-2 secretion by Jurkat cells as measured by ELISA.

Data is representative of the means of two independent experiments +/- SEM. Statistical significances are noted. Dotted lines indicate assay limit of detection. Abbreviations: no Rx, no addition of immunosuppressive agent; CSA, plus the addition of cyclosporin A; FK506, plus the addition of FK506. Experiments depicted are for target therapeutic doses of CSA (200ng/mL) and FK506 $(10 \mathrm{ng} / \mathrm{mL})$.
IL-2 levels were produced by untreated (without the addition of CSA or FK506) stimulated Jurkat cells, significant differences were observed between the levels of IL-2 produced by treated and untreated samples, regardless of the concentration of the agents used (onehalf therapeutic dose, therapeutic dose (Figure 4), or twice the therapeutic dose) or the length of the culture period $(24,36$, or 48 hours). In addition, there was no statistically significant difference found in the suppression of IL-2 production between CSA and FK506 treatments. Both agents were found to inhibit IL-2 production equally and were determined to not interfere with the in vitro IL-2 detection assay. 


\section{Calcineurin activity is inhibited equally by both CSA and FK506.}

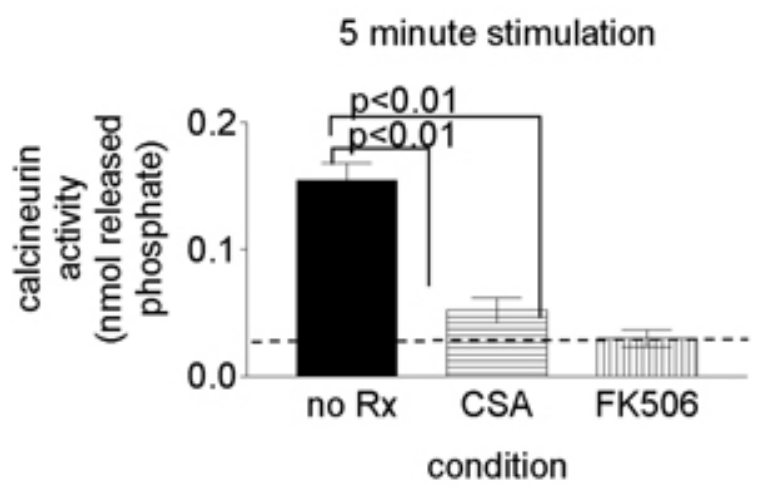

Figure 5: Effects of CSA and FK506 on calcineurin activity in Jurkat cells.

Data is representative of the means of two independent experiments +/- SEM. Statistical significances are noted. Dotted lines indicate assay limit of detection. Abbreviations: no Rx, no addition of immunosuppressive agent; CSA, plus the addition of cyclosporin A; FK506, plus the addition of FK506. Experiments depicted are for target therapeutic doses of CSA $(200 \mathrm{ng} / \mathrm{mL})$ and FK506 (10ng/mL).

The inhibition of IL-2 production by both CSA and FK506 is known to occur by the binding of these agents to their binding partners cyclophilin and FK-binding protein, respectively, and their subsequent inhibition of calcineurin ${ }^{7-12}$. Therefore, the activity of calcineurin in Jurkat cells treated with CSA or FK506 was measured in vitro. Jurkat cells were treated with the therapeutic doses of CSA and FK506 and stimulated with PMA and A23187 calcium ionophore for $5,10,20$, or 30 minutes prior to cellular protein collection. As anticipated, cells treated with either CSA or FK506 resulted in a significant decrease in the activity of calcineurin compared to untreated control cells (Figure 5).

Significant differences, however, were only observed at the five-minute time point and no significant difference was ever observed between CSA and FK506. Additionally, it was determined that neither agent interfered with the detection of the in vitro calcineurin activity assay. 


\section{DISCUSSION}

Despite the fact that both CSA and FK506 inhibit IL-2 production by T cells, different effects were observed on the $T$ cell receptor repertoire in the presence of these immunosuppressive agents in peripheral blood samples from patients undergoing allogeneic peripheral blood stem cell transplant. This observation, however, cannot be attributed to differences in the viability, proliferation, IL-2 production, or calcineurin activity of Jurkat cells treated with CSA versus FK506 in vitro.

Since the in vivo setting is rather complex in experimental variables, we chose to perform in vitro experiments using the Jurkat human T-cell line. T helper cells have been documented to be the main target of CSA and FK506 (according to manufacturers), and this was an additional reason for using Jurkat cells (CD4 ${ }^{+}$) in in vitro experiments. An additional advantage to using this cell line is that Jurkat cells express TCRBV8 ${ }^{19}$, a TCR that showed varied responses to CSA compared to FK506 (Table 1). A decrease in TCRBV8 was seen with CSA whereas no significant response was observed with FK506 treatment.

Two previous reports detailed the changes in the expression of TCRBV8 in response to CSA therapy. Fischer et al., described an increase in TCRBV8.5 in mice following administration of CSA therapy ${ }^{21}$ and Severino et al., reported an increase in the expression of TCRBV8 in CSA-induced murine syngeneic graft-versus-host disease ${ }^{22}$. Although it has been determined that great homology exists between the TCRBV families in mice and humans ${ }^{23}$, there is no report of TCRBV8.5 in humans ${ }^{24}$, making these specific murine studies difficult to directly compare to our study. They do, however, suggest that CSA can exert differed effects on cells carrying a specific TCRBV.

While the inhibition of IL-2 production through the blocking of calcineurin is the accepted mechanism of action for both CSA and FK506 ${ }^{13-16}$, a report by Marton et al., in yeast cells has alluded to the possible existence of a calcineurin-independent pathway for FK506-mediated effects ${ }^{25}$. Using a yeast model and various mutants, they demonstrated that many of the GCN-4 regulated genes were induced by exposure to FK506. GCN-4, a c-Jun/c-Fos homolog, is a eukaryotic transcriptional activator protein that is primarily responsible for the regulation of biosynthetic genes in Saccharomyces 
cerevisiae ${ }^{26-29}$. Although different model systems, both humans and yeast are eukaryotic and a crossover in this alternative pathway may exist. There is also evidence that there is different transcriptional control in humans depending upon the TCRBV usage, with factors such as the promoter and non-coding (spacer) regions contributing to these differences ${ }^{30-35}$.

Our results argue that a secondary mechanism of action for the altered TCRBV repertoire must exist for these immunosuppressive agents as none of the above mentioned parameters, including calcineurin activity, IL-2 production, cell viability and proliferation, exhibited differing effects in response to CSA and FK506 treatments. While the possibility still exists due to our small sample size, we do not believe that these results are attributed to donor variability as results reported were observed across the population of patient/donor pairs, not unique to any single case. Future investigation into alternative mechanisms may yield a clearer understanding of the cellular events responsible for the varying effect on $T$ cells by the related immunosuppressive agents CSA and FK506. 


\section{REFERENCE LIST}

(1) GOWANS JL. The fate of parental strain small lymphocytes in F1 hybrid rats. Ann N Y Acad Sci. 1962;99:432-455.

(2) Kernan NA, Collins NH, Juliano L et al. Clonable T lymphocytes in T celldepleted bone marrow transplants correlate with development of graft-v-host disease. Blood. 1986;68:770-773.

(3) Korngold R, Sprent J. T cell subsets and graft-versus-host disease. Transplantation. 1987;44:335-339.

(4) McGregor DD. Bone marrow origin of immunologically competent lymphocytes in the rat. J Exp Med. 1968;127:953-966.

(5) Ferrara JL, Deeg HJ. Graft-versus-host disease. N Engl J Med. 1991;324:667674.

(6) Borel JF. Pharmacology of cyclosporine (sandimmune). IV. Pharmacological properties in vivo. Pharmacol Rev. 1990;41:259-371.

(7) Handschumacher RE, Harding MW, Rice J, Drugge RJ, Speicher DW. Cyclophilin: a specific cytosolic binding protein for cyclosporin A. Science. 1984;226:544-547.

(8) Harding MW, Handschumacher RE, Speicher DW. Isolation and amino acid sequence of cyclophilin. J Biol Chem. 1986;261:8547-8555.

(9) Harding MW, Galat A, Uehling DE, Schreiber SL. A receptor for the immunosuppressant FK506 is a cis-trans peptidyl-prolyl isomerase. Nature. 1989;341:758-760.

(10) Maki N, Sekiguchi F, Nishimaki J et al. Complementary DNA encoding the human T-cell FK506-binding protein, a peptidylprolyl cis-trans isomerase distinct from cyclophilin. Proc Natl Acad Sci U S A. 1990;87:5440-5443.

(11) Siekierka JJ, Hung SH, Poe M, Lin CS, Sigal NH. A cytosolic binding protein for the immunosuppressant FK506 has peptidyl-prolyl isomerase activity but is distinct from cyclophilin. Nature. 1989;341:755-757.

(12) Standaert RF, Galat A, Verdine GL, Schreiber SL. Molecular cloning and overexpression of the human FK506-binding protein FKBP. Nature. 1990;346:671-674.

(13) Elliott JF, Lin Y, Mizel SB et al. Induction of interleukin 2 messenger RNA inhibited by cyclosporin A. Science. 1984;226:1439-1441. 
(14) Kronke M, Leonard WJ, Depper JM et al. Cyclosporin A inhibits T-cell growth factor gene expression at the level of mRNA transcription. Proc Natl Acad Sci U S A. $1984 ; 81: 5214-5218$.

(15) Metcalfe S. Cyclosporine does not prevent cytoplasmic calcium changes associated with lymphocyte activation. Transplantation. 1984;38:161-164.

(16) Randak C, Brabletz T, Hergenrother M, Sobotta I, Serfling E. Cyclosporin A suppresses the expression of the interleukin 2 gene by inhibiting the binding of lymphocyte-specific factors to the IL-2 enhancer. EMBO J. 1990;9:2529-2536.

(17) Smith KA. Interleukin-2. Curr Opin Immunol. 1992;4:271-276.

(18) Schreiber SL, Crabtree GR. The mechanism of action of cyclosporin A and FK506. Immunol Today. 1992;13:136-142.

(19) Yawalkar N, Ferenczi K, Jones DA et al. Profound loss of T-cell receptor repertoire complexity in cutaneous T-cell lymphoma. Blood. 2003;102:40594066.

(20) Don RH, Cox PT, Wainwright BJ, Baker K, Mattick JS. 'Touchdown' PCR to circumvent spurious priming during gene amplification. Nucleic Acids Res. 1991;19:4008.

(21) Fischer AC, Ruvolo PP, Burt R et al. Characterization of the autoreactive $T$ cell repertoire in cyclosporin-induced syngeneic graft-versus-host disease. A highly conserved repertoire mediates autoaggression. J Immunol. 1995;154:37133725.

(22) Severino ME, Laulis MK, Horwitz LR, Hess AD. Cyclosporine preferentially inhibits clonal deletion of CD8-positive T cells with an MHC class II restricted autoreactive T-cell receptor. Transplant Proc. 1993;25:520-523.

(23) Clark SP, Arden B, Kabelitz D, Mak TW. Comparison of human and mouse Tcell receptor variable gene segment subfamilies. Immunogenetics. 1995;42:531-540.

(24) Arden B, Clark SP, Kabelitz D, Mak TW. Human T-cell receptor variable gene segment families. Immunogenetics. 1995;42:455-500.

(25) Marton MJ, DeRisi JL, Bennett HA et al. Drug target validation and identification of secondary drug target effects using DNA microarrays. Nat Med. 1998;4:1293-1301.

(26) Arndt K, Fink GR. GCN4 protein, a positive transcription factor in yeast, binds general control promoters at all 5' TGACTC 3' sequences. Proc Natl Acad Sci U S A. 1986;83:8516-8520. 
(27) Ben Yosef T, Yanuka O, Benvenisty N. ECA39 is regulated by c-Myc in human and by a Jun/Fos homolog, Gcn4, in yeast. Oncogene. 1996;13:1859-1866.

(28) Drysdale CM, Duenas E, Jackson BM et al. The transcriptional activator GCN4 contains multiple activation domains that are critically dependent on hydrophobic amino acids. Mol Cell Biol. 1995;15:1220-1233.

(29) Hope IA, Struhl K. GCN4, a eukaryotic transcriptional activator protein, binds as a dimer to target DNA. EMBO J. 1987;6:2781-2784.

(30) Deng X, Sun GR, Zheng Q, Li Y. Characterization of human TCR Vbeta gene promoter. Role of the dodecamer motif in promoter activity. J Biol Chem. 1998;273:23709-23715.

(31) Kay RA, Snowden N, Hajeer AH, Boylston AW, Ollier WE. Genetic control of the human $V$ beta 13.2 T cell repertoire: importance of allelic variation outside the coding regions of the TCRBV13S2 gene. Eur J Immunol. 1994;24:28632867.

(32) Li Y, Szabo P, Posnett DN. The genomic structure of human $V$ beta $6 \mathrm{~T}$ cell antigen receptor genes. J Exp Med. 1992;175:617.

(33) Obata F, Shiiba R, lizuka M et al. Human T-cell receptor BV6 gene polymorphism in relation to expression level and CD4/CD8 skewness. Scand J Immunol. 2000;51:543-547.

(34) Posnett DN, Vissinga CS, Pambuccian C et al. Level of human TCRBV3S1 (V beta 3) expression correlates with allelic polymorphism in the spacer region of the recombination signal sequence. J Exp Med. 1994;179:1707-1711.

(35) Vissinga CS, Charmley $\mathrm{P}$, Concannon $\mathrm{P}$. Influence of coding region polymorphism on the peripheral expression of a human TCR $V$ beta gene. J Immunol. 1994;152:1222-1227. 
CHAPTER 6

GENERAL CONCLUSIONS AND DISCUSSION 
The overall goal of this investigation was to identify and study the role of specific T lymphocytes following human hematopoietic stem cell (HSC) transplant. Current literature has stressed the importance of T lymphocytes in this setting but has thus far focused on the identification of specific families of $T$ lymphocytes as it pertains to the occurrence of graft-versus-host disease (GVHD). Several novel findings have emerged from our investigation: (1) a panel of oligonucleotides has been developed to accurately and efficiently detect expression of all known human TCRBV regions, (2) specific TCRBV families are associated with reactivation of cytomegalovirus (CMV) post HSC transplant with many of these same TCRBV families also being associated with the occurrence of GVHD, (3) the TCRBV repertoire engrafts in the recipient with a profile more similar to that found in the donor as opposed to that found in the recipient prior to transplant, and (4) the similar immunosuppressive agents, cyclosporin A (CSA) and tacrolimus (FK506), differentially alter the TCRBV repertoire with their administration.

Prior investigations have used the TCRBV regions to identify specific T cells involved in various settings, such as with GVHD. While our study had initially planned on utilizing prior existing technology to further investigate the role of $\mathrm{T}$ lymphocytes in the post HSC transplant environment, we were unable to locate a method that accurately examined all of the TCRBV genes. To address this, we relied on the TCR gene classification system instituted by the World Health Organization. Using various sequence databases and strict primer sequence specifications, we were able to develop a panel of primers that could be used to accurately and efficiently identify all 91 alleles of the human TCRBV region. Using these primers and sequence specific (TaqMan ${ }^{\circledR}$ probe) real-time PCR detection, we demonstrated that our system was not only specific but also efficient and comparable to TCRBV protein expression profiles. The importance of this technology was realized and has since been protected by both U.S. and foreign patent applications. 
Once a method was available to accurately identify $T$ cells based upon their TCRBV expression, we wanted to apply this technology to our specific area of interest, the post HSC transplant setting. Many prior investigations using human HSC transplant patients have focused on identifying the T cells associated with GVHD. These studies relied on "snapshot" sampling, for example collecting a sample early post transplant and at the time of GVHD diagnosis. Many of these studies also aimed to determine if there was an association of specific T cells in the peripheral blood (PB) and in the GVHD tissue lesion, the lesion frequently being a skin biopsy. In these studies, though, such an association was rarely seen. We believed one explanation for the lack of association of PB and GVHD lesion TCR repertoires was due to the fact that PB and tissue samples were drawn simultaneously. This timing of sample procurement would not accounting for the fact that (1) the development of GVHD is not an instantaneous process and, (2) the $T$ cells expanded in the PB would traffic to the lesion after expansion, resulting in an efflux of these cells from the PB and an influx of these cells into the lesion. In our study, we instituted a serial sampling schedule where baseline samples were collected from both the donor and recipient prior to transplant, with recipient sample collection continuing on a weekly basis post HSC transplant, up to day 100. Day 100 was chosen as our final time point since acute GVHD, by definition, occurs no later than day 100 post transplant. The chronic form of the disease may not appear for several months to years after transplant, yielding a sampling schedule not conducive to our time frame. While our initial plans of obtaining a GVHD lesion sample at time of diagnosis was not fulfilled, we were able to collect PB samples from our study patients on a regular basis. This led us to analyze not only what TCRBV families were involved in GVHD but also those families involved in other post HSC transplant events. 
Our HSC transplant center here at West Virginia University has frequently observed the association of CMV reactivation post transplant and the subsequent development of GVHD. Although there are several studies that support the notion that a link does indeed exist between CMV and GVHD, no such study has looked at the similarity in TCRBV expression with these two complications post HSC transplant. We not only determined which TCRBV families were associated with CMV reactivation in this setting, but were also able to draw parallels between many of these TCRBV families and those also associated with GVHD. Further, many of the families we determined to be associated with CMV reactivation have been previously shown to be CMV reactive in what are considered otherwise healthy human donors. Not only is our study the first to identify those TCRBV families associated with CMV reactivation post HSC transplant, we were also the first to show an overlap in the TCRBV families associated with CMV and GVHD.

Since we had serial TCRBV analysis of our patients, we utilized our data sets to determine if the transplanted donor HSCs developed with a phenotype more reminiscent of that found in the recipient prior to transplant or with greater similarity to the mature profile found in the donor. We expected that the influence of the recipient's environment on these developing HSC would consequently lead to the development of a TCRBV repertoire more reminiscent of that found in the recipient prior to transplant. However, our samples exhibited an engraftment profile with a greater correlation to that found in the donor prior to transplant compared to that initially found in the recipient. While we had a small sample population $(n=4)$ these are the first results we can find to investigate this question. Furthermore, we do not believe these results are attributable to analysis of mature donor $T$ cells initially found within the graft as the patients that exhibited this trend all received Campath-1H therapy that specifically targets the destruction of any residual mature donor $T$ cells found within the graft. The one patient that exhibited a greater correlation to herself than to that found in the donor at the conclusion of the study was the sole patient in our population that did not receive the Campath- $1 \mathrm{H}$ regimen, but received an alternate myeloblative regimen. These results are preliminary but do inspire further thoughts into the contribution of the recipient environment on the development of the transplanted donor cells. 
As a consequence of serial time point analysis and the treatment of all of our study participants with immunosuppressive agents, we observed that the highly similar immunosuppressive agents CSA and FK506, which are both calcineurin inhibitors, had polarized effects on the TCRBV repertoire. FK506 administration resulted in an overall suppression of TCRBV expression while the opposite effect was observed with CSA therapy. Interesting to this observation is the fact that in the HSC transplant setting, FK506 administration is customarily reserved for situations in which greater genetic disparity exists between the recipient and donor, with CSA administration typically being utilized for those transplants with fewer mismatch-related complications anticipated. Potentially our observation could help to explain the immunology behind such pharmacological strategies. To try to determine if there was some facet of the known immunosuppression mechanism of these two agents responsible for contributing to our observed difference, we examined the effect of these two agents in vitro using the human Jurkat $T$ cell line. We determined that while both of these agents did decrease the activity of calcineurin and, subsequently inhibited the production of IL-2, they did so equally well.

Taken together, we feel we have contributed to the understanding of the role of specific T cells in the post HSC transplant environment. While our sample population was large compared to prior similar investigations, we hope that future studies will confirm our results using larger sample populations. Not only has our work contributed to the field of HSC transplantation but also to the field of immunology as a whole. Our TCRBV expression technology vastly improves upon that which existed in the field prior to our entry, and we anticipate the application of our technology to many areas of immunological interest, including the usage of specific TCRBV families during infectious disease, autoimmune disease, graft rejection, and even cancer therapy and graftversus-leukemia effect. Future work will hopefully elucidate a greater understanding of the association of CMV reactivation and GVHD with the identification of specific antigens driving these $T$ cell responses. The possible existence of a secondary mechanism of action for CSA and FK506 will also be investigated in the future and will help to encourage a re-thinking of present treatment strategies. Should all patients not 
be given FK506 as opposed to the present directing of patients into treatment groups based upon the relation of the donor?

In conclusion, one of the most interesting facets of this project was the identity it took over time. As data was generated and the novelties of patient sampling became more apparent, areas that were initially anticipated to be of less interest became increasingly curious and of interest. It reasons that one of the facets to being a good scientist is to set aside pre-conceived notions and approach the data with neutrality. By these means truths are discovered and the field of science marches onward. After all, "the true scientist never loses the faculty of amazement". 


\section{APPENDIX}




\section{Amplification efficiency analysis}

Amplification efficiency analysis for TCRBV primers was determined using the following formula:

Efficiency $(E)=\left(10^{-1 / \text { slope }}\right)-1$

Where the slope is determined by plotting the $\mathrm{Ct}$ value (Y-axis) vs log [cDNA] (X-axis) using 10-fold dilutions of template

Example of equation usage:

slope of amplification plot is determined to be -3.59

$E=\left(10^{-1 /-3.59}\right)-1$

$E=10^{0.28}-1$

$\mathrm{E}=1.90-1$

$E=0.90$, or $90 \%$ efficient

Reference: Rasmussen, R. (2001) Quantification on the LightCycler. In Meuer, S., Wittwer, C. and Nakagawara, K. (eds), Rapid Cycle Real-time PCR, Methods and Applications. Springer Press, Heidelberg, pp. 21-34. 


\section{IOTest $^{\mathrm{TM}}$ Beta Mark TCR VB Repertoire Kit}

The IOTest ${ }^{\mathrm{TM}}$ Beta Mark TCR VB Repertoire Kit (Beckman Coulter, Inc., Fullerton, CA) was used for TCRBV protein expression analysis. Samples were prepared according to the manufacturer's directions using $5 \times 10^{5}$ buffy coat white blood cells per sample, prepared as previously described. To identify $\mathrm{CD}^{+}$cells for TCR analysis an anti-CD3 PC5 antibody and an IgG1 PC5 isotype antibody, each at a volume of $10 \mu \mathrm{l} / \mathrm{sample}$ (Beckman Coulter, Inc.) were used as described in the IOTest ${ }^{\mathrm{TM}}$ kit specifications. Stained samples were then washed in 1X PBS prior to fixation in 500 $\mu \mathrm{l}$ of $1 \%$ paraformaldehyde. All prepared samples were analyzed by flow cytometric analysis using a FACScan (Becton Dickinson, Franklin Lakes, NJ), which had been calibrated using three color Calibrite Beads (Becton Dickinson) and FACSCOMP software (Becton Dickinson). A total of 5,000 live-gated $\mathrm{CD}^{+}$cells were collected for analysis of each IOTest ${ }^{\mathrm{TM}}$ TCR BV expression sample. SSC and FSC data were acquired in the linear mode and the FL1, FL2, and FL3 parameters were collected logarithmically. Data analysis was performed using Windows Multiple Document Interface (WinMDI) version 2.8 (Joseph Trotter, The Scripps Research Institute, http://facs.scripps.edu/spftware.html).

Gating of lymphocytes

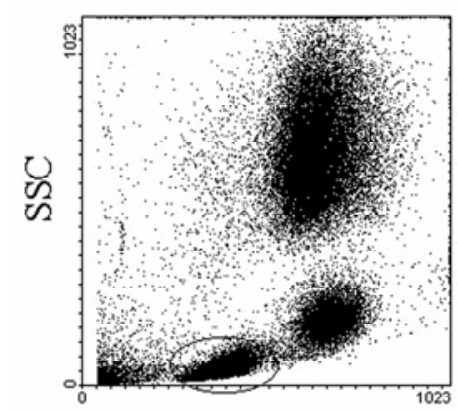

FSC
Gating of CD3+ lymphocytes

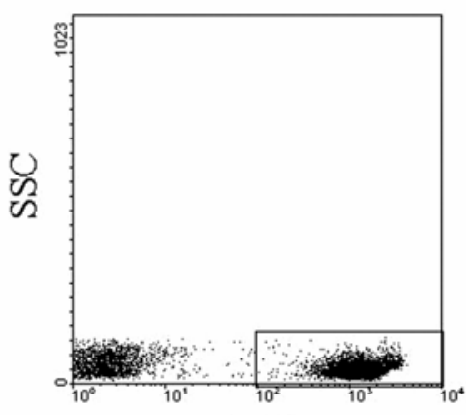

FL3

Gating of $\mathrm{CD}^{+}$lymphocytes for IOTest TCRVB antibody analysis. 

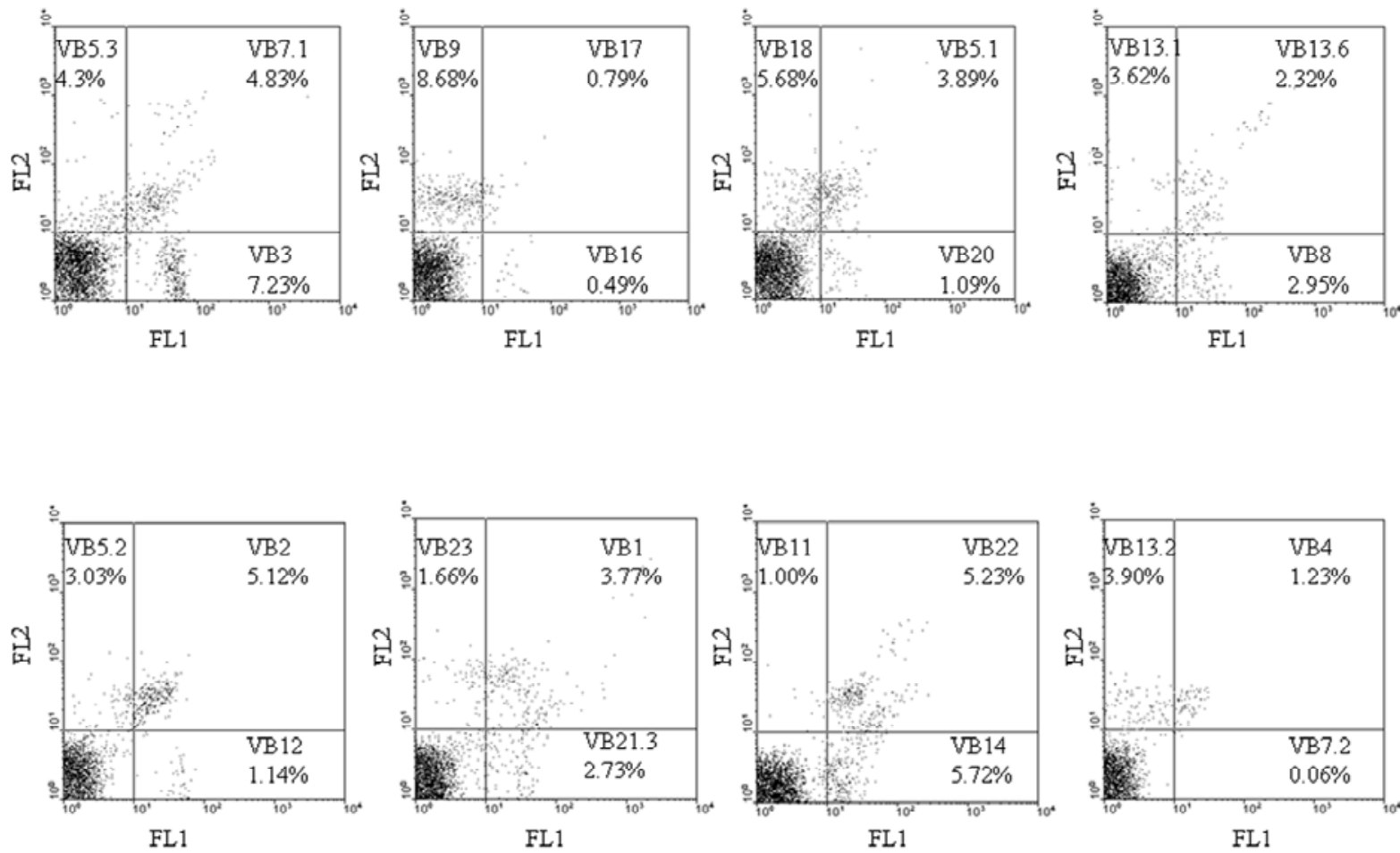

IOTest TCRVB antibody flow cytometric results expressed as percent $\mathrm{CD}^{+}$cells. 


\section{BIOGRAPHICAL SKETCH}

Jamie L. Brewer

West Virginia University

Department of Microbiology, Immunology, and Cell Biology

PO Box 9177

Morgantown, West Virginia

26506-9177

telephone: (304) 293-6965

fax: (304) 293-2134

Email: Jbrewer@hsc.wvu.edu

Residence:

2580 Stewartstown Road

Morgantown, West Virginia

26508

telephone: (304) 598-7952

\section{Academics}

1995 Graduated Valedictorian from Washington Irving High School, Clarksburg, WV Cumulative GPA: 4.073

1999 Graduated Summa Cum Laude from Fairmont State College, Fairmont, WV Cumulative GPA: 4.0

Major: Biology Minor: Chemistry

- West Virginia Academy of Sciences research presentation, $1^{\text {st }}$ place recipient (1998)

o Eleanor M. Ford Outstanding Senior in the Sciences Award, Fairmont State College (1999)

o USA Today All American Academic Team Nominee (1999) 
1999 - West Virginia University Department of Microbiology,

2005 Immunology, and Cell Biology graduate student

o The West Virginia University Health Sciences Center Graduate Student Academic Achievement Award Recipient (2001)

o successfully passed Ph.D. candidacy examinations (written and oral) (2001)

- Van Liere Memorial Research Convocation participant (2002)

- West Virginia Academy of Sciences research presentation (2002)

o International Society for Experimental Hematology research presentation (2002)

o Degree completion date: Summer II 2005 Degree: Ph.D. in Microbiology, Immunology, and Cell Biology

\section{Professional Experiences}

1995-1998 West Virginia University Health Sciences Center Microbiology/Immunology laboratory; studied graft rejection under the direction of Dr. James M. Sheil

1998 Johns Hopkins Medical Institute Immunology laboratory; studied HIV vaccine development under the direction of Dr. Robert F. Siliciano

$1998 \quad$ National Institutes of Health Study Group (top national applicant to accompany Colgate University study team); studied HIV pathogenesis under the direction of Dr. Michael J. Lenardo

1999 West Virginia University Health Sciences Center Cancer Center; studied AFAP-110, a cytoskeletal protein, and its structure under the direction of Dr. Daniel C. Flynn

$2000 \quad$ National Institute of Occupational Safety and Health (NIOSH), Centers for Disease Control, Morgantown, West Virginia; studied T cell cryopreservation under the direction of Dr. Daniel C. Lewis 
2000-2005 West Virginia University Blood and Marrow Transplantation Laboratory; studying T cell recovery (including biological and therapeutic interactions) in patients after blood and bone marrow transplantation under the direction of Dr. Solveig G. Ericson

2001-2005 obtained and maintain Internal Review Board approval and certification for research project

current certified training in the following: chemical safety, handling of blood borne pathogens, handling of patient related samples and information (HIPPA), as well as NIH sponsored training for the usage of human research subject (HPPERT)

\section{$\underline{\text { Scientific Affiliations }}$}

1995-presentBeta Beta Beta Biological Honorary 1996-1997 treasurer of Eta Theta chapter 1997-1998 vice president of Eta Theta chapter 1997-1998 outstanding member of the year

1995-1999 American Chemical Society

1996-2002 West Virginia Academy of Sciences

1997-presentAssociation for Women in the Sciences

1999 Discover Magazine reader advisory panel

1999-2001 American Society of Microbiologists

\section{External, competitive funding}

1997 Association for Women in the Sciences/National Science Foundation grant recipient $(\$ 2,000.00)$

1998 Association for Women in the Sciences/National Science Foundation grant recipient $(\$ 2,000.00)$

1998 Burnside Academic Scholarship recipient (\$2,000.00)

1999 Burnside Presidential Scholarship recipient $(\$ 3,000.00)$

2001 Burnside Presidential Scholarship recipient $(\$ 1,000.00)$ 


\section{Publications}

1. Brewer, J., Frankenberry, M., Sheil, J. Important features of class I major histocompatibility complex (MHC) molecules for alloreactive T cell recognition. WV

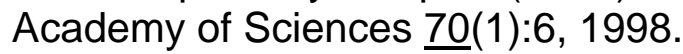

2. Ericson, S., Henderson, A., Brewer, J., Kavanaugh, K., Blobaum, A., Gibson, L. Anti-thymocyte globulin treatment of neutrophils in vitro can induce inflammatory responses as well as cell death. Experimental Hematology 29(8) Supp. 1:62, 2001.

3. Brewer, J., Ericson, S. Developing a methodology to detect human T cell receptor variable family gene expression patterns. WV Academy of Sciences, accepted, 2002.

4. Brewer, J., Ericson, S. Developing a methodology to detect human T cell receptor variable family gene expression patterns in graft-vs-host disease patients. International Society for Experimental Hematology, accepted, 2002.

5. Brewer, J., Henderson, A., Kavanaugh, K., VanDyke, B., Blobaum, A., and Ericson, $\mathrm{S}$. The effects of antithymocyte globulin (ATG) on human neutrophil functioning. Manuscript in preparation for submission.

6. Brewer, J., and Ericson S. U.S. and Foreign Patents Pending:

Development of a methodology to detect expression of human $\mathrm{T}$ cell receptor variable family gene expression patterns.

7. Brewer, J., and Ericson S. An Improved Methodology to Detect Human T cell Receptor Beta Variable Family Gene Expression Patterns. In press, 2005, Journal of Immunological Methods

8. Brewer, J., and Ericson S. Similarity in repertoire of $\mathrm{T}$ cells associated with the occurrence of Cytomegalovirus reactivation and Graft-versus-Host Disease post human hematopoietic stem cell transplantation. Manuscript submitted.

9. Brewer, J., and Ericson S. Cyclosporine A (CSA) and tacrolimus (FK506) differentially alter T cell receptor (TCR) expression in vivo. Manuscript submitted.

10. Brewer, J., and Ericson S. Engraftment of $T$ cell receptor (TCR) repertoire in myeloablated allogeneic hematopoietic stem cell recipients mimics donor TCR repertoire. Manuscript submitted. 


\section{Laboratory Technique Experience}

RNA, DNA, and protein isolation

gel electrophoresis and SDS-PAGE

Southern Blotting

Western Blotting

Flow cytometry and FACS analysis

PCR, RT-PCR, Realtime PCR

DNA sequencing

Primer and Taqman probe design

Genomic analysis

ELISA

Cell separation: columns, density, and magnetic separation

$\mathrm{CsCl}$ gradient ultracentrifugation

radioactive isotype labeling

chromium release assay

dissection and organ harvesting

intraperitonial injections

sterile cell culture

bacterial culture, including selective and differential media culturing

viral culture

HPLC

NMR

Gas Chromatography

spectroscopy

Infrared Analysis (IR)

Ultraviolet Analysis (UV)

Atomic Absorption (AA)

titrimetric analysis

potentiometric analysis

DNA Methylation

cloning

recombination and transformation procedures

restriction mapping

genomic library construction

DNA sequencing

TUNEL

caspase assays

annexin analysis

cell proliferation analysis (CFSE tracking)

confocal microscopy

electron microscopy

transwell assays

venipuncture techniques and peripheral blood cell isolation

P3 laboratory experience 


\section{CUMULATIVE REFERENCES}

Clinical Bone Marrow and Blood Stem Cell Transplantation. second ed. New York: Cambridge University Press; 2000.

Abe J, Forrester J, Nakahara T et al. Selective stimulation of human T cells with streptococcal erythrogenic toxins A and B. J Immunol. 1991;146:3747-3750.

Abe J, Forrester J, Nakahara T et al. Selective stimulation of human T cells with streptococcal erythrogenic toxins A and B. J Immunol. 1991;146:3747-3750.

Abe J, Forrester J, Nakahara T et al. Selective stimulation of human T cells with streptococcal erythrogenic toxins A and B. J Immunol. 1991;146:3747-3750.

Abe J, Forrester J, Nakahara T et al. Selective stimulation of human T cells with streptococcal erythrogenic toxins A and B. J Immunol. 1991;146:3747-3750.

Abe J, Kotzin $\mathrm{BL}$, Jujo $\mathrm{K}$ et al. Selective expansion of $\mathrm{T}$ cells expressing T-cell receptor variable regions $\mathrm{V}$ beta 2 and V beta 8 in Kawasaki disease. Proc Natl Acad Sci U S A. 1992;89:4066-4070.

Abe J, Kotzin BL, Jujo $\mathrm{K}$ et al. Selective expansion of $\mathrm{T}$ cells expressing $\mathrm{T}$-cell receptor variable regions $\mathrm{V}$ beta 2 and V beta 8 in Kawasaki disease. Proc Natl Acad Sci U S A. 1992;89:4066-4070.

Abe J, Kotzin BL, Jujo $\mathrm{K}$ et al. Selective expansion of $\mathrm{T}$ cells expressing $\mathrm{T}$-cell receptor variable regions $\mathrm{V}$ beta 2 and V beta 8 in Kawasaki disease. Proc Natl Acad Sci U S A. 1992;89:4066-4070.

Abe J, Kotzin BL, Jujo $\mathrm{K}$ et al. Selective expansion of $\mathrm{T}$ cells expressing T-cell receptor variable regions $\mathrm{V}$ beta 2 and V beta 8 in Kawasaki disease. Proc Natl Acad Sci U S A. 1992;89:4066-4070.

Akatsuka Y, Cerveny C, Hansen JA. T cell receptor clonal diversity following allogeneic marrow grafting. Hum Immunol. 1996;48:125-134.

Akolkar PN, Gulwani-Akolkar B, Pergolizzi R, Bigler RD, Silver J. Influence of HLA genes on T cell receptor $\mathrm{V}$ segment frequencies and expression levels in peripheral blood lymphocytes. J Immunol. 1993;150:2761-2773.

Alyea EP, Canning C, Neuberg D et al. CD8+ cell depletion of donor lymphocyte infusions using cd8 monoclonal antibody-coated high-density microparticles (CD8-HDM) after allogeneic hematopoietic stem cell transplantation: a pilot study. Bone Marrow Transplant. 2004;34:123-128.

Anderlini P, Przepiorka D, Champlin R, Korbling M. Biologic and clinical effects of granulocyte colonystimulating factor in normal individuals. Blood. 1996;88:2819-2825.

Arden B, Clark SP, Kabelitz D, Mak TW. Human T-cell receptor variable gene segment families. Immunogenetics. 1995;42:455-500.

Arndt K, Fink GR. GCN4 protein, a positive transcription factor in yeast, binds general control promoters at all 5' TGACTC 3' sequences. Proc Natl Acad Sci U S A. 1986;83:8516-8520.

Arstila TP, Casrouge A, Baron V et al. A direct estimate of the human alphabeta T cell receptor diversity. Science. 1999;286:958-961. 
Atkinson K. Reconstruction of the haemopoietic and immune systems after marrow transplantation. Bone Marrow Transplant. 1990;5:209-226.

Atkinson K, Hansen JA, Storb R et al. T-cell subpopulations identified by monoclonal antibodies after human marrow transplantation. I. Helper-inducer and cytotoxic-suppressor subsets. Blood. 1982;59:12921298.

Azevedo WM, Aranha FJ, Gouvea JV et al. Allogeneic transplantation with blood stem cells mobilized by rhG-CSF for hematological malignancies. Bone Marrow Transplant. 1995;16:647-653.

Barker JN, Davies SM, DeFor T et al. Survival after transplantation of unrelated donor umbilical cord blood is comparable to that of human leukocyte antigen-matched unrelated donor bone marrow: results of a matched-pair analysis. Blood. 2001;97:2957-2961.

Barnardo MC, Davey NJ, Bunce $M$ et al. A correlation between HLA-C matching and donor antirecipient CTL precursor frequency in bone marrow transplantation. Transplantation. 1996;61:1420-1423.

BARNES DW, CORP MJ, LOUTIT JF, NEAL FE. Treatment of murine leukaemia with X rays and homologous bone marrow; preliminary communication. Br Med J. 1956;32:626-627.

Ben Nun A, Liblau RS, Cohen $L$ et al. Restricted T-cell receptor $V$ beta gene usage by myelin basic protein-specific T-cell clones in multiple sclerosis: predominant genes vary in individuals. Proc Natl Acad Sci U S A. 1991;88:2466-2470.

Ben Nun A, Liblau RS, Cohen $L$ et al. Restricted T-cell receptor $V$ beta gene usage by myelin basic protein-specific T-cell clones in multiple sclerosis: predominant genes vary in individuals. Proc Natl Acad Sci U S A. 1991;88:2466-2470.

Ben Nun A, Liblau RS, Cohen $L$ et al. Restricted T-cell receptor $V$ beta gene usage by myelin basic protein-specific T-cell clones in multiple sclerosis: predominant genes vary in individuals. Proc Natl Acad Sci U S A. 1991;88:2466-2470.

Ben Nun A, Liblau RS, Cohen $L$ et al. Restricted T-cell receptor $V$ beta gene usage by myelin basic protein-specific T-cell clones in multiple sclerosis: predominant genes vary in individuals. Proc Natl Acad Sci U S A. 1991;88:2466-2470.

Ben Yosef T, Yanuka O, Benvenisty N. ECA39 is regulated by c-Myc in human and by a Jun/Fos homolog, Gcn4, in yeast. Oncogene. 1996;13:1859-1866.

Bensinger WI, Buckner CD, Shannon-Dorcy K et al. Transplantation of allogeneic CD34+ peripheral blood stem cells in patients with advanced hematologic malignancy. Blood. 1996;88:4132-4138.

Bensinger WI, Clift R, Martin P et al. Allogeneic peripheral blood stem cell transplantation in patients with advanced hematologic malignancies: a retrospective comparison with marrow transplantation. Blood. 1996;88:2794-2800.

Bensinger WI, Storb R. Allogeneic peripheral blood stem cell transplantation. Rev Clin Exp Hematol. 2001;5:67-86.

Bevan $\mathrm{MJ}$. In a radiation chimaera, host $\mathrm{H}-2$ antigens determine immune responsiveness of donor cytotoxic cells. Nature. 1977;269:417-418.

Billingham RE, Brent L. Quantitative studies on tissue transplantation immunity. IV. Induction of tolerance in newborn mice and studies on the phenomenon of runt disease. Philos Trans R Soc Lond B Biol Sci. 1959;242:477. 
BILLINGHAM RE, BRENT L. A simple method for inducing tolerance of skin homografts in mice. Transplant Bull. 1957;4:67-71.

Bitmansour AD, Douek DC, Maino VC, Picker LJ. Direct ex vivo analysis of human CD4(+) memory T cell activation requirements at the single clonotype level. J Immunol. 2002;169:1207-1218.

Bitmansour AD, Waldrop SL, Pitcher CJ et al. Clonotypic structure of the human CD4+ memory T cell response to cytomegalovirus. J Immunol. 2001;167:1151-1163.

Blumberg RS, Yockey CE, Gross GG, Ebert EC, Balk SP. Human intestinal intraepithelial lymphocytes are derived from a limited number of $\mathrm{T}$ cell clones that utilize multiple $\mathrm{V}$ beta $\mathrm{T}$ cell receptor genes. $\mathrm{J}$ Immunol. 1993;150:5144-5153.

Blumberg RS, Yockey CE, Gross GG, Ebert EC, Balk SP. Human intestinal intraepithelial lymphocytes are derived from a limited number of $\mathrm{T}$ cell clones that utilize multiple $\mathrm{V}$ beta $\mathrm{T}$ cell receptor genes. $\mathrm{J}$ Immunol. 1993;150:5144-5153.

Blumberg RS, Yockey CE, Gross GG, Ebert EC, Balk SP. Human intestinal intraepithelial lymphocytes are derived from a limited number of $\mathrm{T}$ cell clones that utilize multiple $\mathrm{V}$ beta $\mathrm{T}$ cell receptor genes. $\mathrm{J}$ Immunol. 1993;150:5144-5153.

Blumberg RS, Yockey CE, Gross GG, Ebert EC, Balk SP. Human intestinal intraepithelial lymphocytes are derived from a limited number of $\mathrm{T}$ cell clones that utilize multiple $\mathrm{V}$ beta $\mathrm{T}$ cell receptor genes. $\mathrm{J}$ Immunol. 1993;150:5144-5153.

Blumberg RS, Yockey CE, Gross GG, Ebert EC, Balk SP. Human intestinal intraepithelial lymphocytes are derived from a limited number of $\mathrm{T}$ cell clones that utilize multiple $\mathrm{V}$ beta $\mathrm{T}$ cell receptor genes. $\mathrm{J}$ Immunol. 1993;150:5144-5153.

Bodmer JG, Marsh SG, Albert ED et al. Nomenclature for factors of the HLA system, 1996. Tissue Antigens. 1997;49:297-321.

Borel JF. Pharmacology of cyclosporine (sandimmune). IV. Pharmacological properties in vivo. Pharmacol Rev. 1990;41:259-371.

Bragado R, Lauzurica P, Lopez D, Lopez de Castro JA. T cell receptor $V$ beta gene usage in a human alloreactive response. Shared structural features among HLA-B27-specific T cell clones. J Exp Med. 1990;171:1189-1204.

Bragado R, Lauzurica P, Lopez D, Lopez de Castro JA. T cell receptor $V$ beta gene usage in a human alloreactive response. Shared structural features among HLA-B27-specific T cell clones. J Exp Med. 1990;171:1189-1204.

Bragado R, Lauzurica P, Lopez D, Lopez de Castro JA. T cell receptor $V$ beta gene usage in a human alloreactive response. Shared structural features among HLA-B27-specific T cell clones. J Exp Med. 1990;171:1189-1204.

Bragado R, Lauzurica $\mathrm{P}$, Lopez D, Lopez de Castro JA. T cell receptor $\mathrm{V}$ beta gene usage in a human alloreactive response. Shared structural features among HLA-B27-specific T cell clones. J Exp Med. 1990;171:1189-1204.

Cavazzana-Calvo M, Andre-Schmutz I, Hacein-Bey-Abina S et al. Improving immune reconstitution while preventing graft-versus-host disease in allogeneic stem cell transplantation. Semin Hematol. 2002;39:3240. 
Chakraverty R, Robinson S, Peggs $\mathrm{K}$ et al. Excessive $\mathrm{T}$ cell depletion of peripheral blood stem cells has an adverse effect upon outcome following allogeneic stem cell transplantation. Bone Marrow Transplant. 2001;28:827-834.

Choi YW, Kotzin B, Herron L et al. Interaction of Staphylococcus aureus toxin "superantigens" with human T cells. Proc Natl Acad Sci U S A. 1989;86:8941-8945.

Choi YW, Kotzin B, Herron L et al. Interaction of Staphylococcus aureus toxin "superantigens" with human T cells. Proc Natl Acad Sci U S A. 1989;86:8941-8945.

Choi YW, Kotzin B, Herron L et al. Interaction of Staphylococcus aureus toxin "superantigens" with human T cells. Proc Natl Acad Sci U S A. 1989;86:8941-8945.

Choi YW, Kotzin B, Herron L et al. Interaction of Staphylococcus aureus toxin "superantigens" with human T cells. Proc Natl Acad Sci U S A. 1989;86:8941-8945.

Clark SP, Arden B, Kabelitz D, Mak TW. Comparison of human and mouse T-cell receptor variable gene segment subfamilies. Immunogenetics. 1995;42:531-540.

Clift RA, Buckner CD, Appelbaum FR et al. Allogeneic marrow transplantation in patients with acute myeloid leukemia in first remission: a randomized trial of two irradiation regimens. Blood. 1990;76:18671871.

Cohen Y, Nagler A. Cord blood biology and transplantation. Isr Med Assoc J. 2004;6:39-46.

Cooke KR, Gerbitz A, Crawford JM et al. LPS antagonism reduces graft-versus-host disease and preserves graft-versus-leukemia activity after experimental bone marrow transplantation. J Clin Invest. 2001;107:1581-1589.

de Bueger M, Bakker A, van Rood JJ, Van der WF, Goulmy E. Tissue distribution of human minor histocompatibility antigens. Ubiquitous versus restricted tissue distribution indicates heterogeneity among human cytotoxic T lymphocyte-defined non-MHC antigens. J Immunol. 1992;149:1788-1794.

DeBruyne LA, Lynch JP, III, Baker LA et al. Restricted $\mathrm{V}$ beta usage by $\mathrm{T}$ cells infiltrating rejecting human lung allografts. J Immunol. 1996;156:3493-3500.

Deeg HJ, Yamaguchi M. Acute graft-versus-host disease. In: Atkinson K, ed. Clinical Bone Marrow and Blood Stem Cell Transplantation. New York: Cambridge University Press; 2000:681-699.

Deng X, Sun GR, Zheng Q, Li Y. Characterization of human TCR Vbeta gene promoter. Role of the dodecamer motif in promoter activity. J Biol Chem. 1998;273:23709-23715.

Dietrich PY, Caignard A, Diu A et al. Analysis of T-cell receptor variability in transplanted patients with acute graft-versus-host disease. Blood. 1992;80:2419-2424.

Dietrich PY, Caignard A, Diu A et al. Analysis of T-cell receptor variability in transplanted patients with acute graft-versus-host disease. Blood. 1992;80:2419-2424.

Dietrich PY, Caignard A, Diu A et al. Analysis of T-cell receptor variability in transplanted patients with acute graft-versus-host disease. Blood. 1992;80:2419-2424.

Dietrich PY, Caignard A, Diu A et al. Analysis of T-cell receptor variability in transplanted patients with acute graft-versus-host disease. Blood. 1992;80:2419-2424. 
Dietrich PY, Caignard A, Diu A et al. Analysis of T-cell receptor variability in transplanted patients with acute graft-versus-host disease. Blood. 1992;80:2419-2424.

Dietrich PY, Caignard A, Lim A et al. In vivo T-cell clonal amplification at time of acute graft-versus-host disease. Blood. 1994;84:2815-2820.

Dombret H, Loiseau P, Bories JC, Sigaux F. Unexpected consistent involvement of $\mathrm{V}$ beta gene segments in inappropriate T-cell receptor beta gene rearrangements occurring in B-lineage acute lymphoblastic leukemias. Blood. 1992;80:2614-2621.

Dombret $\mathrm{H}$, Loiseau P, Bories JC, Sigaux F. Unexpected consistent involvement of $\mathrm{V}$ beta gene segments in inappropriate T-cell receptor beta gene rearrangements occurring in B-lineage acute lymphoblastic leukemias. Blood. 1992;80:2614-2621.

Dombret H, Loiseau P, Bories JC, Sigaux F. Unexpected consistent involvement of $\mathrm{V}$ beta gene segments in inappropriate T-cell receptor beta gene rearrangements occurring in B-lineage acute lymphoblastic leukemias. Blood. 1992;80:2614-2621.

Dombret H, Loiseau P, Bories JC, Sigaux F. Unexpected consistent involvement of $\mathrm{V}$ beta gene segments in inappropriate T-cell receptor beta gene rearrangements occurring in B-lineage acute lymphoblastic leukemias. Blood. 1992;80:2614-2621.

Don RH, Cox PT, Wainwright BJ, Baker K, Mattick JS. 'Touchdown' PCR to circumvent spurious priming during gene amplification. Nucleic Acids Res. 1991;19:4008.

Don RH, Cox PT, Wainwright BJ, Baker K, Mattick JS. 'Touchdown' PCR to circumvent spurious priming during gene amplification. Nucleic Acids Res. 1991;19:4008.

Don RH, Cox PT, Wainwright BJ, Baker K, Mattick JS. 'Touchdown' PCR to circumvent spurious priming during gene amplification. Nucleic Acids Res. 1991;19:4008.

Dreger P, Haferlach T, Eckstein V et al. G-CSF-mobilized peripheral blood progenitor cells for allogeneic transplantation: safety, kinetics of mobilization, and composition of the graft. Br J Haematol. 1994;87:609613.

Drobyski WR. Evolving strategies to address adverse transplant outcomes associated with $\mathrm{T}$ cell depletion. J Hematother Stem Cell Res. 2000;9:327-337.

Drysdale CM, Duenas E, Jackson BM et al. The transcriptional activator GCN4 contains multiple activation domains that are critically dependent on hydrophobic amino acids. Mol Cell Biol. 1995;15:12201233.

Dumont FJ. CAMPATH (alemtuzumab) for the treatment of chronic lymphocytic leukemia and beyond. Expert Rev Anticancer Ther. 2002;2:23-35.

Elkington R, Khanna R. Cross-recognition of human alloantigen by cytomegalovirus glycoprotein-specific CD4+ cytotoxic T lymphocytes: implications for graft-versus-host disease. Blood. 2005;105:1362-1364.

Elliott JF, Lin Y, Mizel SB et al. Induction of interleukin 2 messenger RNA inhibited by cyclosporin A. Science. 1984;226:1439-1441.

Epperson DE, Margolis DA, McOlash L, Janczak T, Barrett AJ. In vitro T-cell receptor $V$ beta repertoire analysis may identify which $\mathrm{T}$-cell $\mathrm{V}$ beta families mediate graft-versus-leukaemia and graft-versus-host responses after human leucocyte antigen-matched sibling stem cell transplantation. $\mathrm{Br} \mathrm{J}$ Haematol. 2001;114:57-62. 
Even J, Lim A, Puisieux I et al. T-cell repertoires in healthy and diseased human tissues analysed by Tcell receptor beta-chain CDR3 size determination: evidence for oligoclonal expansions in tumours and inflammatory diseases. Res Immunol. 1995;146:65-80.

Even J, Lim A, Puisieux I et al. T-cell repertoires in healthy and diseased human tissues analysed by Tcell receptor beta-chain CDR3 size determination: evidence for oligoclonal expansions in tumours and inflammatory diseases. Res Immunol. 1995;146:65-80.

Even J, Lim A, Puisieux I et al. T-cell repertoires in healthy and diseased human tissues analysed by Tcell receptor beta-chain CDR3 size determination: evidence for oligoclonal expansions in tumours and inflammatory diseases. Res Immunol. 1995;146:65-80.

Even J, Lim A, Puisieux I et al. T-cell repertoires in healthy and diseased human tissues analysed by Tcell receptor beta-chain CDR3 size determination: evidence for oligoclonal expansions in tumours and inflammatory diseases. Res Immunol. 1995;146:65-80.

Ferrara JL, Deeg HJ. Graft-versus-host disease. N Engl J Med. 1991;324:667-674.

Festenstein H, Demant P. HLA and H-2 basic immunogenetics, biology, and clinical relevance. In: Turk J, ed. Current Topics in Immunology. London: Edward Arnold; 1978:212.

Fink PJ, Bevan MJ. H-2 antigens of the thymus determine lymphocyte specificity. J Exp Med. 1978;148:766-775.

Fischer AC, Ruvolo PP, Burt R et al. Characterization of the autoreactive T cell repertoire in cyclosporininduced syngeneic graft-versus-host disease. A highly conserved repertoire mediates autoaggression. J Immunol. 1995;154:3713-3725.

Fleischhauer K, Kernan NA, O'Reilly RJ, Dupont B, Yang SY. Bone marrow-allograft rejection by T lymphocytes recognizing a single amino acid difference in HLA-B44. N Engl J Med. 1990;323:1818-1822.

Frassoni F, Podesta M, Maccario R et al. Cord blood transplantation provides better reconstitution of hematopoietic reservoir compared with bone marrow transplantation. Blood. 2003;102:1138-1141.

Friedman TM, Gilbert M, Briggs C, Korngold R. Repertoire analysis of CD8+ T cell responses to minor histocompatibility antigens involved in graft-versus-host disease. J Immunol. 1998;161:41-48.

Friedman TM, Statton D, Jones SC et al. Vbeta spectratype analysis reveals heterogeneity of CD4+ T-cell responses to minor histocompatibility antigens involved in graft-versus-host disease: correlations with epithelial tissue infiltrate. Biol Blood Marrow Transplant. 2001;7:2-13.

Fujimaki K, Maruta A, Yoshida $\mathrm{M}$ et al. Immune reconstitution assessed during five years after allogeneic bone marrow transplantation. Bone Marrow Transplant. 2001;27:1275-1281.

Gagne K, Brouard S, Giral M et al. Highly altered V beta repertoire of T cells infiltrating long-term rejected kidney allografts. J Immunol. 2000;164:1553-1563.

Gagne K, Brouard S, Giral M et al. Highly altered V beta repertoire of T cells infiltrating long-term rejected kidney allografts. J Immunol. 2000;164:1553-1563.

Gagne K, Brouard S, Giral M et al. Highly altered V beta repertoire of T cells infiltrating long-term rejected kidney allografts. J Immunol. 2000;164:1553-1563.

Gagne K, Brouard S, Giral M et al. Highly altered V beta repertoire of T cells infiltrating long-term rejected kidney allografts. J Immunol. 2000;164:1553-1563. 
Gale RP, Bortin MM, van Bekkum DW et al. Risk factors for acute graft-versus-host disease. Br J Haematol. 1987;67:397-406.

Genevee C, Diu A, Nierat J et al. An experimentally validated panel of subfamily-specific oligonucleotide primers ( $V$ alpha 1-w29/V beta 1-w24) for the study of human T cell receptor variable $V$ gene segment usage by polymerase chain reaction. Eur J Immunol. 1992;22:1261-1269.

Genevee C, Diu A, Nierat J et al. An experimentally validated panel of subfamily-specific oligonucleotide primers ( $V$ alpha 1-w29/V beta 1-w24) for the study of human T cell receptor variable $V$ gene segment usage by polymerase chain reaction. Eur J Immunol. 1992;22:1261-1269.

Genevee C, Diu A, Nierat J et al. An experimentally validated panel of subfamily-specific oligonucleotide primers ( $V$ alpha 1-w29/V beta 1-w24) for the study of human $T$ cell receptor variable $V$ gene segment usage by polymerase chain reaction. Eur J Immunol. 1992;22:1261-1269.

Genevee C, Diu A, Nierat J et al. An experimentally validated panel of subfamily-specific oligonucleotide primers ( $V$ alpha 1-w29/V beta 1-w24) for the study of human T cell receptor variable $V$ gene segment usage by polymerase chain reaction. Eur J Immunol. 1992;22:1261-1269.

Genevee C, Diu A, Nierat J et al. An experimentally validated panel of subfamily-specific oligonucleotide primers ( $V$ alpha 1-w29/V beta 1-w24) for the study of human T cell receptor variable $V$ gene segment usage by polymerase chain reaction. Eur J Immunol. 1992;22:1261-1269.

Ghayur T, Seemayer T, Lapp WS. Histological correlates of immune functional deficits in graft-versushost disease. In: Burakoff SJ, Deeg HJ, Ferrara J, Atkinson K, eds. Graft-versus-Host Disease: Immunology, Pathophysiology, and Treatment. New York: Marcel Dekker, Inc.; 1990:109-132.

Gifford GE, Lohmann-Matthes ML. Gamma interferon priming of mouse and human macrophages for induction of tumor necrosis factor production by bacterial lipopolysaccharide. J Natl Cancer Inst. 1987;78:121-124.

Gorer PA. The antigenic basis of tumor transplantation. J Pathol Bacteriol. 1938;47:231.

Gorochov G, Debre P, Leblond V et al. Oligoclonal expansion of CD8+ CD57+ T cells with restricted Tcell receptor beta chain variability after bone marrow transplantation. Blood. 1994;83:587-595.

Gorochov G, Debre P, Leblond V et al. Oligoclonal expansion of CD8+ CD57+ T cells with restricted Tcell receptor beta chain variability after bone marrow transplantation. Blood. 1994;83:587-595.

Gorochov G, Debre P, Leblond V et al. Oligoclonal expansion of CD8+ CD57+ T cells with restricted Tcell receptor beta chain variability after bone marrow transplantation. Blood. 1994;83:587-595.

Gorochov G, Debre P, Leblond V et al. Oligoclonal expansion of CD8+ CD57+ T cells with restricted Tcell receptor beta chain variability after bone marrow transplantation. Blood. 1994;83:587-595.

Gorski J, Yassai M, Zhu X et al. Circulating T cell repertoire complexity in normal individuals and bone marrow recipients analyzed by CDR3 size spectratyping. Correlation with immune status. J Immunol. 1994;152:5109-5119.

Gorski J, Yassai M, Zhu X et al. Circulating T cell repertoire complexity in normal individuals and bone marrow recipients analyzed by CDR3 size spectratyping. Correlation with immune status. J Immunol. 1994;152:5109-5119. 
Gorski J, Yassai M, Zhu X et al. Circulating T cell repertoire complexity in normal individuals and bone marrow recipients analyzed by CDR3 size spectratyping. Correlation with immune status. J Immunol. 1994;152:5109-5119.

Gorski J, Yassai M, Zhu X et al. Circulating T cell repertoire complexity in normal individuals and bone marrow recipients analyzed by CDR3 size spectratyping. Correlation with immune status. J Immunol. 1994;152:5109-5119.

Gorski J, Yassai M, Zhu X et al. Circulating T cell repertoire complexity in normal individuals and bone marrow recipients analyzed by CDR3 size spectratyping. Correlation with immune status. J Immunol. 1994;152:5109-5119.

Goulmy E, Gratama JW, Blokland E, Zwaan FE, van Rood JJ. A minor transplantation antigen detected by MHC-restricted cytotoxic T lymphocytes during graft-versus-host disease. Nature. 1983;302:159-161.

GOWANS JL. The fate of parental strain small lymphocytes in F1 hybrid rats. Ann N Y Acad Sci. 1962;99:432-455.

Handschumacher RE, Harding MW, Rice J, Drugge RJ, Speicher DW. Cyclophilin: a specific cytosolic binding protein for cyclosporin A. Science. 1984;226:544-547.

Harding MW, Galat A, Uehling DE, Schreiber SL. A receptor for the immunosuppressant FK506 is a cistrans peptidyl-prolyl isomerase. Nature. 1989;341:758-760.

Harding MW, Handschumacher RE, Speicher DW. Isolation and amino acid sequence of cyclophilin. J Biol Chem. 1986;261:8547-8555.

Henslee-Downey PJ, Parrish RS, MacDonald JS et al. Combined in vitro and in vivo T lymphocyte depletion for the control of graft-versus-host disease following haploidentical marrow transplant. Transplantation. 1996;61:738-745.

Herve P, Flesch M, Tiberghien $\mathrm{P}$ et al. Phase I-II trial of a monoclonal anti-tumor necrosis factor alpha antibody for the treatment of refractory severe acute graft-versus-host disease. Blood. 1992;79:33623368.

Hess AD, Fischer AC. Immune mechanisms in cyclosporine-induced syngeneic graft-versus-host disease. Transplantation. 1989;48:895-900.

Hill GR, Crawford JM, Cooke KR et al. Total body irradiation and acute graft-versus-host disease: the role of gastrointestinal damage and inflammatory cytokines. Blood. 1997;90:3204-3213.

Hirokawa M, Matsutani T, Horiuchi T et al. Extensive clonal expansion of T lymphocytes causes contracted diversity of complementarity-determining region 3 and skewed $T$ cell receptor repertoires after allogeneic hematopoietic cell transplantation. Bone Marrow Transplant. 2001;27:607-614.

Hirokawa M, Matsutani T, Horiuchi T et al. Extensive clonal expansion of T lymphocytes causes contracted diversity of complementarity-determining region 3 and skewed T cell receptor repertoires after allogeneic hematopoietic cell transplantation. Bone Marrow Transplant. 2001;27:607-614.

Hirokawa M, Matsutani T, Horiuchi T et al. Extensive clonal expansion of T lymphocytes causes contracted diversity of complementarity-determining region 3 and skewed T cell receptor repertoires after allogeneic hematopoietic cell transplantation. Bone Marrow Transplant. 2001;27:607-614. 
Hirokawa M, Matsutani T, Saitoh H et al. Distinct TCRAV and TCRBV repertoire and CDR3 sequence of T lymphocytes clonally expanded in blood and GVHD lesions after human allogeneic bone marrow transplantation. Bone Marrow Transplant. 2002;30:915-923.

Hirokawa M, Matsutani T, Saitoh $\mathrm{H}$ et al. Distinct TCRAV and TCRBV repertoire and CDR3 sequence of T lymphocytes clonally expanded in blood and GVHD lesions after human allogeneic bone marrow transplantation. Bone Marrow Transplant. 2002;30:915-923.

Hirokawa M, Matsutani T, Saitoh $\mathrm{H}$ et al. Distinct TCRAV and TCRBV repertoire and CDR3 sequence of T lymphocytes clonally expanded in blood and GVHD lesions after human allogeneic bone marrow transplantation. Bone Marrow Transplant. 2002;30:915-923.

Hirokawa M, Matsutani T, Saitoh $\mathrm{H}$ et al. Distinct TCRAV and TCRBV repertoire and CDR3 sequence of T lymphocytes clonally expanded in blood and GVHD lesions after human allogeneic bone marrow transplantation. Bone Marrow Transplant. 2002;30:915-923.

Ho VT, Kim HT, Li S et al. Partial CD8+ T-cell depletion of allogeneic peripheral blood stem cell transplantation is insufficient to prevent graft-versus-host disease. Bone Marrow Transplant. 2004;34:987994.

Holler E, Kolb HJ, Hintermeier-Knabe R et al. Role of tumor necrosis factor alpha in acute graft-versushost disease and complications following allogeneic bone marrow transplantation. Transplant Proc. 1993;25:1234-1236.

Holler E, Kolb HJ, Moller A et al. Increased serum levels of tumor necrosis factor alpha precede major complications of bone marrow transplantation. Blood. 1990;75:1011-1016.

Hope IA, Struhl K. GCN4, a eukaryotic transcriptional activator protein, binds as a dimer to target DNA. EMBO J. 1987;6:2781-2784.

Huber C, Niederwieser D. Role of cytokines and major histocompatibility complex antigens in graftversus-host disease: in vitro studies using T-cell lines and keratinocytes or hemopoietic targets. Haematol Blood Transfus. 1990;33:652-654.

Ikeda $\mathrm{H}$, Sato N, Matsuura A, Kikuchi K. Analysis of T-cell receptor $\mathrm{V}$ region gene usage of cytotoxic Tlymphocytes and tumor-infiltrating lymphocytes derived from human autologous gastric signet ring cell carcinomas. Cancer Res. 1993;53:3078-3084.

Ikeda $\mathrm{H}$, Sato N, Matsuura A, Kikuchi K. Analysis of T-cell receptor $\mathrm{V}$ region gene usage of cytotoxic Tlymphocytes and tumor-infiltrating lymphocytes derived from human autologous gastric signet ring cell carcinomas. Cancer Res. 1993;53:3078-3084.

Ikeda $\mathrm{H}$, Sato N, Matsuura A, Kikuchi K. Analysis of T-cell receptor $\mathrm{V}$ region gene usage of cytotoxic Tlymphocytes and tumor-infiltrating lymphocytes derived from human autologous gastric signet ring cell carcinomas. Cancer Res. 1993;53:3078-3084.

Ikeda $\mathrm{H}$, Sato N, Matsuura A, Kikuchi K. Analysis of T-cell receptor $\mathrm{V}$ region gene usage of cytotoxic Tlymphocytes and tumor-infiltrating lymphocytes derived from human autologous gastric signet ring cell carcinomas. Cancer Res. 1993;53:3078-3084.

Inoue $\mathrm{H}$, Yasuda $\mathrm{Y}$, Hattori $\mathrm{K}$ et al. The kinetics of immune reconstitution after cord blood transplantation and selected CD34+ stem cell transplantation in children: comparison with bone marrow transplantation. Int J Hematol. 2003;77:399-407. 
Irle C, Beatty PG, Mickelson E, THOMAS ED, Hansen JA. Alloreactive T cell responses between HLAidentical siblings. Detection of anti-minor histocompatibility $\mathrm{T}$ cell clones induced in vivo. Transplantation. 1985;40:329-333.

Johnston A, Gudjonsson JE, Sigmundsdottir H, Ludviksson BR, Valdimarsson $\mathrm{H}$. The anti-inflammatory action of methotrexate is not mediated by lymphocyte apoptosis, but by the suppression of activation and adhesion molecules. Clin Immunol. 2005;114:154-163.

Jones JM, Wilson R, Bealmear PM. Mortality and gross pathology of secondary disease in germfree mouse radiation chimeras. Radiat Res. 1971;45:577-588.

Kalams SA, Johnson RP, Dynan MJ et al. T cell receptor usage and fine specificity of human immunodeficiency virus 1-specific cytotoxic T lymphocyte clones: analysis of quasispecies recognition reveals a dominant response directed against a minor in vivo variant. J Exp Med. 1996;183:1669-1679.

Kalams SA, Johnson RP, Dynan MJ et al. T cell receptor usage and fine specificity of human immunodeficiency virus 1-specific cytotoxic T lymphocyte clones: analysis of quasispecies recognition reveals a dominant response directed against a minor in vivo variant. J Exp Med. 1996;183:1669-1679.

Kalams SA, Johnson RP, Dynan MJ et al. T cell receptor usage and fine specificity of human immunodeficiency virus 1-specific cytotoxic T lymphocyte clones: analysis of quasispecies recognition reveals a dominant response directed against a minor in vivo variant. J Exp Med. 1996;183:1669-1679.

Kalams SA, Johnson RP, Dynan MJ et al. T cell receptor usage and fine specificity of human immunodeficiency virus 1-specific cytotoxic T lymphocyte clones: analysis of quasispecies recognition reveals a dominant response directed against a minor in vivo variant. J Exp Med. 1996;183:1669-1679.

Kalams SA, Johnson RP, Trocha AK et al. Longitudinal analysis of T cell receptor (TCR) gene usage by human immunodeficiency virus 1 envelope-specific cytotoxic T lymphocyte clones reveals a limited TCR repertoire. J Exp Med. 1994;179:1261-1271.

Kalams SA, Johnson RP, Trocha AK et al. Longitudinal analysis of T cell receptor (TCR) gene usage by human immunodeficiency virus 1 envelope-specific cytotoxic T lymphocyte clones reveals a limited TCR repertoire. J Exp Med. 1994;179:1261-1271.

Kalams SA, Johnson RP, Trocha AK et al. Longitudinal analysis of T cell receptor (TCR) gene usage by human immunodeficiency virus 1 envelope-specific cytotoxic T lymphocyte clones reveals a limited TCR repertoire. J Exp Med. 1994;179:1261-1271.

Kalams SA, Johnson RP, Trocha AK et al. Longitudinal analysis of T cell receptor (TCR) gene usage by human immunodeficiency virus 1 envelope-specific cytotoxic T lymphocyte clones reveals a limited TCR repertoire. J Exp Med. 1994;179:1261-1271.

Kay RA, Snowden N, Hajeer AH, Boylston AW, Ollier WE. Genetic control of the human V beta 13.2 T cell repertoire: importance of allelic variation outside the coding regions of the TCRBV13S2 gene. Eur J Immunol. 1994;24:2863-2867.

Keever CA, Abu-Hajir M, Graf W et al. Characterization of the alloreactivity and anti-leukemia reactivity of cord blood mononuclear cells. Bone Marrow Transplant. 1995;15:407-419.

Kernan NA, Bordignon C, Keever CA et al. Graft failures after T cell depleted marrow transplants for leukemia: clinical and in vitro characteristics. Transplant Proc. 1987;19:29-32.

Kernan NA, Collins NH, Juliano L et al. Clonable T lymphocytes in T cell-depleted bone marrow transplants correlate with development of graft-v-host disease. Blood. 1986;68:770-773. 
Kernan NA, Flomenberg N, Dupont B, O'Reilly RJ. Graft rejection in recipients of T-cell-depleted HLAnonidentical marrow transplants for leukemia. Identification of host-derived antidonor allocytotoxic $T$ lymphocytes. Transplantation. 1987;43:842-847.

Khan N, Shariff N, Cobbold M et al. Cytomegalovirus seropositivity drives the CD8 T cell repertoire toward greater clonality in healthy elderly individuals. J Immunol. 2002;169:1984-1992.

Kirk AD. Immunosuppression without immunosuppression? How to be a tolerant individual in a dangerous world. Transplant Infectious Disease. 1999;1:65-75.

Korngold R, Sprent J. T cell subsets and graft-versus-host disease. Transplantation. 1987;44:335-339.

Krensky AM, Weiss A, Crabtree G, Davis MM, Parham P. T-lymphocyte-antigen interactions in transplant rejection. N Engl J Med. 1990;322:510-517.

Kronenberg M, Siu G, Hood LE, Shastri N. The molecular genetics of the T-cell antigen receptor and Tcell antigen recognition. Annu Rev Immunol. 1986;4:529-591.

Kronke M, Leonard WJ, Depper JM et al. Cyclosporin A inhibits T-cell growth factor gene expression at the level of mRNA transcription. Proc Natl Acad Sci U S A. 1984;81:5214-5218.

Kubo H, Abe J, Obata $\mathrm{F}$ et al. Dual recognition of a human cytotoxic T-cell clone for melanoma antigens. Cancer Res. 1996;56:2368-2374.

Kubo H, Abe J, Obata F et al. Dual recognition of a human cytotoxic T-cell clone for melanoma antigens. Cancer Res. 1996;56:2368-2374.

Kubo H, Abe J, Obata F et al. Dual recognition of a human cytotoxic T-cell clone for melanoma antigens. Cancer Res. 1996;56:2368-2374.

Kubo $\mathrm{H}$, Abe J, Obata $\mathrm{F}$ et al. Dual recognition of a human cytotoxic T-cell clone for melanoma antigens. Cancer Res. 1996;56:2368-2374.

Kubo K, Yamanaka K, Kiyoi H et al. Different T-cell receptor repertoires between lesions and peripheral blood in acute graft-versus-host disease after allogeneic bone marrow transplantation. Blood. 1996;87:3019-3026.

Kuijpers KC, van Dongen JJ, van der BP et al. A combined immunodeficiency with oligoclonal CD8+, V beta 3-expressing, cytotoxic T lymphocytes in the peripheral blood. J Immunol. 1992;149:3403-3410.

Kuijpers KC, van Dongen JJ, van der BP et al. A combined immunodeficiency with oligoclonal CD8+, V beta 3-expressing, cytotoxic T lymphocytes in the peripheral blood. J Immunol. 1992;149:3403-3410.

Kuijpers KC, van Dongen JJ, van der BP et al. A combined immunodeficiency with oligoclonal CD8+, V beta 3-expressing, cytotoxic T lymphocytes in the peripheral blood. J Immunol. 1992;149:3403-3410.

Kuijpers KC, van Dongen JJ, van der BP et al. A combined immunodeficiency with oligoclonal CD8+, V beta 3-expressing, cytotoxic T lymphocytes in the peripheral blood. J Immunol. 1992;149:3403-3410.

KURNICK NB, MONTANO A, GERDES JC, FEDER BH. Preliminary observations on the treatment of postirradiation hematopoietic depression in man by the infusion of stored autogenous bone marrow. Ann Intern Med. 1958;49:973-986.

Kusaka S, Grailer AP, Fechner JH, Jr. et al. Clonotype analysis of human alloreactive T cells: a novel approach to studying peripheral tolerance in a transplant recipient. J Immunol. 2000;164:2240-2247. 
Kusaka S, Grailer AP, Fechner JH, Jr. et al. Clonotype analysis of human alloreactive T cells: a novel approach to studying peripheral tolerance in a transplant recipient. J Immunol. 2000;164:2240-2247.

Kusaka S, Grailer AP, Fechner JH, Jr. et al. Clonotype analysis of human alloreactive T cells: a novel approach to studying peripheral tolerance in a transplant recipient. J Immunol. 2000;164:2240-2247.

Kusaka S, Grailer AP, Fechner JH, Jr. et al. Clonotype analysis of human alloreactive T cells: a novel approach to studying peripheral tolerance in a transplant recipient. J Immunol. 2000;164:2240-2247.

Labalette M, Salez F, Pruvot FR, Noel C, Dessaint JP. CD8 lymphocytosis in primary cytomegalovirus (CMV) infection of allograft recipients: expansion of an uncommon CD8+. Clin Exp Immunol. 1994; $95: 465-471$.

Lang $\mathrm{R}$, Pfeffer $\mathrm{K}$, Wagner $\mathrm{H}$, Heeg K. A rapid method for semiquantitative analysis of the human $\mathrm{V}$ betarepertoire using TaqManR PCR. J Immunol Methods. 1997;203:181-192.

Lang R, Pfeffer K, Wagner $\mathrm{H}$, Heeg K. A rapid method for semiquantitative analysis of the human $\mathrm{V}$ betarepertoire using TaqManR PCR. J Immunol Methods. 1997;203:181-192.

Lang $\mathrm{R}$, Pfeffer $\mathrm{K}$, Wagner $\mathrm{H}$, Heeg K. A rapid method for semiquantitative analysis of the human $\mathrm{V}$ betarepertoire using TaqManR PCR. J Immunol Methods. 1997;203:181-192.

Lang $\mathrm{R}$, Pfeffer $\mathrm{K}$, Wagner $\mathrm{H}$, Heeg K. A rapid method for semiquantitative analysis of the human $\mathrm{V}$ betarepertoire using TaqManR PCR. J Immunol Methods. 1997;203:181-192.

Larsson K, Aschan J, Remberger M et al. Reduced risk for extensive chronic graft-versus-host disease in patients receiving transplants with human leukocyte antigen-identical sibling donors given polymerase chain reaction-based preemptive therapy against cytomegalovirus. Transplantation. 2004;77:526-531.

Laughlin MJ, Eapen M, Rubinstein P et al. Outcomes After Transplantation of Cord Blood or Bone Marrow From Unrelated Donors in Adults With Leukemia. Obstet Gynecol Surv. 2005;60:295-296.

Lee $C$, Brouillette $M$, Lamb $L$ et al. Use of a closed system for $V$ alpha beta-positive $T$ cell depletion of marrow for use in partially mismatched related donor (PMRD) transplantation. Prog Clin Biol Res. 1994;389:523-532.

Lee SJ, Zahrieh D, Alyea EP et al. Comparison of T-cell-depleted and non-T-cell-depleted unrelated donor transplantation for hematologic diseases: clinical outcomes, quality of life, and costs. Blood. 2002;100:2697-2702.

Lewin SR, Heller G, Zhang L et al. Direct evidence for new T-cell generation by patients after either Tcell-depleted or unmodified allogeneic hematopoietic stem cell transplantations. Blood. 2002;100:22352242.

Li Y, Szabo P, Posnett DN. The genomic structure of human $\mathrm{V}$ beta $6 \mathrm{~T}$ cell antigen receptor genes. J Exp Med. 1992;175:617.

Lima M, Teixeira MA, Queiros ML et al. Immunophenotype and TCR-Vbeta repertoire of peripheral blood T-cells in acute infectious mononucleosis. Blood Cells Mol Dis. 2003;30:1-12.

Liu J, Farmer JD, Jr., Lane WS et al. Calcineurin is a common target of cyclophilin-cyclosporin A and FKBP-FK506 complexes. Cell. 1991;66:807-815. 
Liu X, Chesnokova V, Forman SJ, Diamond DJ. Molecular analysis of T-cell receptor repertoire in bone marrow transplant recipients: evidence for oligoclonal T-cell expansion in graft-versus-host disease lesions. Blood. 1996;87:3032-3044.

Liu X, Chesnokova V, Forman SJ, Diamond DJ. Molecular analysis of T-cell receptor repertoire in bone marrow transplant recipients: evidence for oligoclonal T-cell expansion in graft-versus-host disease lesions. Blood. 1996;87:3032-3044.

Liu X, Chesnokova V, Forman SJ, Diamond DJ. Molecular analysis of T-cell receptor repertoire in bone marrow transplant recipients: evidence for oligoclonal T-cell expansion in graft-versus-host disease lesions. Blood. 1996;87:3032-3044.

Liu X, Chesnokova V, Forman SJ, Diamond DJ. Molecular analysis of T-cell receptor repertoire in bone marrow transplant recipients: evidence for oligoclonal T-cell expansion in graft-versus-host disease lesions. Blood. 1996;87:3032-3044.

Liu X, Chesnokova V, Forman SJ, Diamond DJ. Molecular analysis of T-cell receptor repertoire in bone marrow transplant recipients: evidence for oligoclonal T-cell expansion in graft-versus-host disease lesions. Blood. 1996;87:3032-3044.

LORENZ E, UPHOFF D, REID TR, SHELTON E. Modification of irradiation injury in mice and guinea pigs by bone marrow injections. J Natl Cancer Inst. 1951;12:197-201.

Lynas C, Howe D. Additional TCRV beta primers and minor method modifications improve detection of clonal T-cell populations by RT-PCR. Mol Pathol. 1997;50:53-55.

Lynas C, Howe D. Additional TCRV beta primers and minor method modifications improve detection of clonal T-cell populations by RT-PCR. Mol Pathol. 1997;50:53-55.

Lynas C, Howe D. Additional TCRV beta primers and minor method modifications improve detection of clonal T-cell populations by RT-PCR. Mol Pathol. 1997;50:53-55.

Lynas C, Howe D. Additional TCRV beta primers and minor method modifications improve detection of clonal T-cell populations by RT-PCR. Mol Pathol. 1997;50:53-55.

Lynas C, Howe D. Additional TCRV beta primers and minor method modifications improve detection of clonal T-cell populations by RT-PCR. Mol Pathol. 1997;50:53-55.

Maki N, Sekiguchi F, Nishimaki J et al. Complementary DNA encoding the human T-cell FK506-binding protein, a peptidylprolyl cis-trans isomerase distinct from cyclophilin. Proc Natl Acad Sci U S A. 1990;87:5440-5443.

Margolis DA, Casper JT, Segura AD et al. Infiltrating T cells during liver graft-versus-host disease show a restricted T-cell repertoire. Biol Blood Marrow Transplant. 2000;6:408-415.

Marijt WA, Kernan NA, Diaz-Barrientos T et al. Multiple minor histocompatibility antigen-specific cytotoxic T lymphocyte clones can be generated during graft rejection after HLA-identical bone marrow transplantation. Bone Marrow Transplant. 1995;16:125-132.

Marks DI, Bird JM, Vettenranta $\mathrm{K}$ et al. T cell-depleted unrelated donor bone marrow transplantation for acute myeloid leukemia. Biol Blood Marrow Transplant. 2000;6:646-653.

Martin PJ, Hansen JA, Buckner CD et al. Effects of in vitro depletion of T cells in HLA-identical allogeneic marrow grafts. Blood. 1985;66:664-672. 
Martin PJ, Rowley SD, Anasetti C et al. A phase I-II clinical trial to evaluate removal of CD4 cells and partial depletion of CD8 cells from donor marrow for HLA-mismatched unrelated recipients. Blood. 1999;94:2192-2199.

Martino R, Martin-Henao G, Sureda A et al. Allogeneic peripheral blood stem cell transplantation with CD34+-cell selection and delayed T-cell add-back in adults. Results of a single center pilot study.

Haematologica. 2000;85:1165-1171.

Marton MJ, DeRisi JL, Bennett HA et al. Drug target validation and identification of secondary drug target effects using DNA microarrays. Nat Med. 1998;4:1293-1301.

Maslanka K, Piatek T, Gorski J, Yassai M, Gorski J. Molecular analysis of T cell repertoires. Spectratypes generated by multiplex polymerase chain reaction and evaluated by radioactivity or fluorescence. Hum Immunol. 1995;44:28-34.

Maslanka K, Piatek T, Gorski J, Yassai M, Gorski J. Molecular analysis of T cell repertoires. Spectratypes generated by multiplex polymerase chain reaction and evaluated by radioactivity or fluorescence. Hum Immunol. 1995;44:28-34.

Maslanka K, Piatek T, Gorski J, Yassai M, Gorski J. Molecular analysis of T cell repertoires. Spectratypes generated by multiplex polymerase chain reaction and evaluated by radioactivity or fluorescence. Hum Immunol. 1995;44:28-34.

Maslanka K, Piatek T, Gorski J, Yassai M, Gorski J. Molecular analysis of T cell repertoires. Spectratypes generated by multiplex polymerase chain reaction and evaluated by radioactivity or fluorescence. Hum Immunol. 1995;44:28-34.

Mason DW, Dallman M, Barclay AN. Graft-versus-host disease induces expression of la antigen in rat epidermal cells and gut epithelium. Nature. 1981;293:150-151.

Mathe G, Amiel JL, Schwarzenberg L, Cattan A, Schneider M. Adoptive immunotherapy of acute leukemia: experimental and clinical results. Cancer Res. 1965;25:1525-1531.

Mathe G, JAMMET H, PENDIC B et al. [Transfusions and grafts of homologous bone marrow in humans after accidental high dosage irradiation.]. Rev Fr Etud Clin Biol. 1959;4:226-238.

Matsutani T, Yoshioka T, Tsuruta Y, Iwagami S, Suzuki R. Analysis of TCRAV and TCRBV repertoires in healthy individuals by microplate hybridization assay. Hum Immunol. 1997;56:57-69.

Matsutani T, Yoshioka T, Tsuruta Y, Iwagami S, Suzuki R. Analysis of TCRAV and TCRBV repertoires in healthy individuals by microplate hybridization assay. Hum Immunol. 1997;56:57-69.

Matsutani T, Yoshioka T, Tsuruta Y, Iwagami S, Suzuki R. Analysis of TCRAV and TCRBV repertoires in healthy individuals by microplate hybridization assay. Hum Immunol. 1997;56:57-69.

Matsutani T, Yoshioka T, Tsuruta $Y$ et al. Restricted usage of T-cell receptor alpha-chain variable region (TCRAV) and T-cell receptor beta-chain variable region (TCRBV) repertoires after human allogeneic haematopoietic transplantation. Br J Haematol. 2000;109:759-769.

Mavroudis DA, Dermime S, Molldrem J et al. Specific depletion of alloreactive T cells in HLA-identical siblings: a method for separating graft-versus-host and graft-versus-leukaemia reactions. $\mathrm{Br} \mathrm{J}$ Haematol. 1998;101:565-570.

McCarthy KP, Sloane JP, Kabarowski JH, Matutes E, Wiedemann LM. The rapid detection of clonal T-cell proliferations in patients with lymphoid disorders. Am J Pathol. 1991;138:821-828. 
McCarthy KP, Sloane JP, Kabarowski JH, Matutes E, Wiedemann LM. The rapid detection of clonal T-cell proliferations in patients with lymphoid disorders. Am J Pathol. 1991;138:821-828.

McCarthy KP, Sloane JP, Kabarowski JH, Matutes E, Wiedemann LM. The rapid detection of clonal T-cell proliferations in patients with lymphoid disorders. Am J Pathol. 1991;138:821-828.

McCarthy KP, Sloane JP, Kabarowski JH, Matutes E, Wiedemann LM. The rapid detection of clonal T-cell proliferations in patients with lymphoid disorders. Am J Pathol. 1991;138:821-828.

McCarthy PL, Jr., Abhyankar S, Neben S et al. Inhibition of interleukin-1 by an interleukin-1 receptor antagonist prevents graft-versus-host disease. Blood. 1991;78:1915-1918.

McGregor DD. Bone marrow origin of immunologically competent lymphocytes in the rat. J Exp Med. 1968;127:953-966.

Medawar PB. The immunology of transplantation. Harvey Lecture Series. 1958;52:144.

Metcalfe S. Cyclosporine does not prevent cytoplasmic calcium changes associated with lymphocyte activation. Transplantation. 1984;38:161-164.

Michalek J, Collins RH, Durrani HP et al. Definitive separation of graft-versus-leukemia- and graft-versushost-specific CD4+ T cells by virtue of their receptor beta loci sequences. Proc Natl Acad Sci U S A. 2003;100:1180-1184.

Morecki S, Gelfand Y, Nagler A et al. Immune reconstitution following allogeneic stem cell transplantation in recipients conditioned by low intensity vs myeloablative regimen. Bone Marrow Transplant. 2001;28:243-249.

Mowat AM. Antibodies to IFN-gamma prevent immunologically mediated intestinal damage in murine graft-versus-host reaction. Immunology. 1989;68:18-23.

Muluk SC, Hakim FT, Shearer GM. Regulation of graft-versus-host-reaction by Mlsa-reactive donor T cells. Eur J Immunol. 1992;22:1967-1973.

Nikaein A, Poole T, Fishbeck R et al. Characterization of skin-infiltrating cells during acute graft-versushost disease following bone marrow transplantation using unrelated marrow donors. Hum Immunol. 1994;40:68-76.

Nuovo GJ, Morrison C, Porcu P, Caligiuri MA, Suster S. In situ determination of T-cell receptor beta expression patterns. J Histochem Cytochem. 2001;49:139-145.

Nuovo GJ, Morrison C, Porcu P, Caligiuri MA, Suster S. In situ determination of T-cell receptor beta expression patterns. J Histochem Cytochem. 2001;49:139-145.

Nuovo GJ, Morrison C, Porcu P, Caligiuri MA, Suster S. In situ determination of T-cell receptor beta expression patterns. J Histochem Cytochem. 2001;49:139-145.

Nuovo GJ, Morrison C, Porcu P, Caligiuri MA, Suster S. In situ determination of T-cell receptor beta expression patterns. J Histochem Cytochem. 2001;49:139-145.

O'Brien SN, Blijlevens NM, Mahfouz TH, Anaissie EJ. Infections in patients with hematological cancer: recent developments. Hematology (Am Soc Hematol Educ Program ). 2003;438-472.

Oaks MK, Downs JA, Tector AJ. T-cell receptor alpha and beta chain gene expression in cells infiltrating human cardiac allografts. Am J Med Sci. 1995;309:26-34. 
Oaks MK, Downs JA, Tector AJ. T-cell receptor alpha and beta chain gene expression in cells infiltrating human cardiac allografts. Am J Med Sci. 1995;309:26-34.

Oaks MK, Downs JA, Tector AJ. T-cell receptor alpha and beta chain gene expression in cells infiltrating human cardiac allografts. Am J Med Sci. 1995;309:26-34.

Oaks MK, Downs JA, Tector AJ. T-cell receptor alpha and beta chain gene expression in cells infiltrating human cardiac allografts. Am J Med Sci. 1995;309:26-34.

Obata F, Shiiba R, lizuka M et al. Human T-cell receptor BV6 gene polymorphism in relation to expression level and CD4/CD8 skewness. Scand J Immunol. 2000;51:543-547.

Orsini E, Alyea EP, Schlossman $\mathrm{R}$ et al. Changes in $\mathrm{T}$ cell receptor repertoire associated with graftversus-tumor effect and graft-versus-host disease in patients with relapsed multiple myeloma after donor lymphocyte infusion. Bone Marrow Transplant. 2000;25:623-632.

Orsini E, Alyea EP, Schlossman $\mathrm{R}$ et al. Changes in $\mathrm{T}$ cell receptor repertoire associated with graftversus-tumor effect and graft-versus-host disease in patients with relapsed multiple myeloma after donor lymphocyte infusion. Bone Marrow Transplant. 2000;25:623-632.

Orsini E, Alyea EP, Schlossman $\mathrm{R}$ et al. Changes in $\mathrm{T}$ cell receptor repertoire associated with graftversus-tumor effect and graft-versus-host disease in patients with relapsed multiple myeloma after donor lymphocyte infusion. Bone Marrow Transplant. 2000;25:623-632.

Orsini E, Alyea EP, Schlossman $\mathrm{R}$ et al. Changes in $\mathrm{T}$ cell receptor repertoire associated with graftversus-tumor effect and graft-versus-host disease in patients with relapsed multiple myeloma after donor lymphocyte infusion. Bone Marrow Transplant. 2000;25:623-632.

Panigrahi S, Morecki S, Yacovlev E et al. A novel approach for prevention of lethal GVHD by selective elimination of alloreactive donor lymphocytes prior to stem cell transplantation. Exp Hematol. 2004;32:756-764.

Panzara MA, Gussoni E, Steinman L, Oksenberg JR. Analysis of the T cell repertoire using the PCR and specific oligonucleotide primers. Biotechniques. 1992;12:728-735.

Panzara MA, Gussoni E, Steinman L, Oksenberg JR. Analysis of the T cell repertoire using the PCR and specific oligonucleotide primers. Biotechniques. 1992;12:728-735.

Panzara MA, Gussoni E, Steinman L, Oksenberg JR. Analysis of the T cell repertoire using the PCR and specific oligonucleotide primers. Biotechniques. 1992;12:728-735.

Panzara MA, Gussoni E, Steinman L, Oksenberg JR. Analysis of the T cell repertoire using the PCR and specific oligonucleotide primers. Biotechniques. 1992;12:728-735.

Parham P, Ohta T. Population biology of antigen presentation by MHC class I molecules. Science. 1996;272:67-74.

Parkman R, Lenarsky C, Barrantes B, et al. Cytokines versus cytotoxic T lymphocytes (CTL) in the pathogenesis of acute graft-versus-host disease (GVHD). J Cellular Biochem. 1992;16a (Supp):186.

Petersdorf EW, Longton GM, Anasetti $C$ et al. The significance of HLA-DRB1 matching on clinical outcome after HLA-A, B, DR identical unrelated donor marrow transplantation. Blood. 1995;86:16061613. 
Petersdorf EW, Longton GM, Anasetti C et al. Association of HLA-C disparity with graft failure after marrow transplantation from unrelated donors. Blood. 1997;89:1818-1823.

Petersdorf EW, Longton GM, Anasetti C et al. Definition of HLA-DQ as a transplantation antigen. Proc Natl Acad Sci U S A. 1996;93:15358-15363.

Petersdorf EW, Smith AG, Mickelson EM et al. The role of HLA-DPB1 disparity in the development of acute graft-versus-host disease following unrelated donor marrow transplantation. Blood. 1993;81:19231932.

Petrie HT. Role of thymic organ structure and stromal composition in steady-state postnatal T-cell production. Immunol Rev. 2002;189:8-19.

Piguet PF, Grau GE, Allet B, Vassalli P. Tumor necrosis factor/cachectin is an effector of skin and gut lesions of the acute phase of graft-vs.-host disease. J Exp Med. 1987;166:1280-1289.

Pilch $\mathrm{H}, \mathrm{Hohn} \mathrm{H}$, Freitag $\mathrm{K}$ et al. Improved assessment of T-cell receptor (TCR) VB repertoire in clinical specimens: combination of TCR-CDR3 spectratyping with flow cytometry-based TCR VB frequency analysis. Clin Diagn Lab Immunol. 2002;9:257-266.

Pilch H, Hohn H, Freitag K et al. Improved assessment of T-cell receptor (TCR) VB repertoire in clinical specimens: combination of TCR-CDR3 spectratyping with flow cytometry-based TCR VB frequency analysis. Clin Diagn Lab Immunol. 2002;9:257-266.

Pilch H, Hohn H, Freitag K et al. Improved assessment of T-cell receptor (TCR) VB repertoire in clinical specimens: combination of TCR-CDR3 spectratyping with flow cytometry-based TCR VB frequency analysis. Clin Diagn Lab Immunol. 2002;9:257-266.

Pilch H, Hohn H, Freitag K et al. Improved assessment of T-cell receptor (TCR) VB repertoire in clinical specimens: combination of TCR-CDR3 spectratyping with flow cytometry-based TCR VB frequency analysis. Clin Diagn Lab Immunol. 2002;9:257-266.

Posnett DN, Vissinga CS, Pambuccian C et al. Level of human TCRBV3S1 (V beta 3) expression correlates with allelic polymorphism in the spacer region of the recombination signal sequence. $J$ Exp Med. 1994;179:1707-1711.

Power M, Rosenbloom AJ. Immunological Aspects of Transplant Management: Pharmacotherapy and Rejection. Journal of Intensive Care Medicine. 2000;15:126.

Przepiorka D, Ippoliti C, Khouri I et al. Allogeneic transplantation for advanced leukemia: improved shortterm outcome with blood stem cell grafts and tacrolimus. Transplantation. 1996;62:1806-1810.

Puisieux I, Even J, Pannetier $\mathrm{C}$ et al. Oligoclonality of tumor-infiltrating lymphocytes from human melanomas. J Immunol. 1994;153:2807-2818.

Puisieux I, Even J, Pannetier C et al. Oligoclonality of tumor-infiltrating lymphocytes from human melanomas. J Immunol. 1994;153:2807-2818.

Puisieux I, Even J, Pannetier $\mathrm{C}$ et al. Oligoclonality of tumor-infiltrating lymphocytes from human melanomas. J Immunol. 1994;153:2807-2818.

Puisieux I, Even J, Pannetier C et al. Oligoclonality of tumor-infiltrating lymphocytes from human melanomas. J Immunol. 1994;153:2807-2818. 
Randak C, Brabletz T, Hergenrother M, Sobotta I, Serfling E. Cyclosporin A suppresses the expression of the interleukin 2 gene by inhibiting the binding of lymphocyte-specific factors to the IL-2 enhancer. EMBO J. 1990;9:2529-2536.

Rencher SD, Houston JA, Lockey TD, Hurwitz JL. Eliminating graft-versus-host potential from T cell immunotherapeutic populations. Bone Marrow Transplant. 1996;18:415-420.

Rice A, Reiffers J. Mobilized blood stem cells: immunophenotyping and functional characteristics. J Hematother. 1992;1:19-26.

Ringden O. Viral infections and graft-vs.host disease. In: Burakoff SJ, Deeg HJ, Ferrara J, Atkinson K, eds. Graft-vs.-Host Disease. New York: Marcel Dekker, Inc.; 1990:467.

Rocha V, Cornish J, Sievers EL et al. Comparison of outcomes of unrelated bone marrow and umbilical cord blood transplants in children with acute leukemia. Blood. 2001;97:2962-2971.

Roers A, Montesinos-Rongen M, Hansmann ML, Rajewsky K, Kuppers R. Amplification of TCRbeta gene rearrangements from micromanipulated single cells: T cells rosetting around Hodgkin and ReedSternberg cells in Hodgkin's disease are polyclonal. Eur J Immunol. 1998;28:2424-2431.

Roers A, Montesinos-Rongen M, Hansmann ML, Rajewsky K, Kuppers R. Amplification of TCRbeta gene rearrangements from micromanipulated single cells: T cells rosetting around Hodgkin and ReedSternberg cells in Hodgkin's disease are polyclonal. Eur J Immunol. 1998;28:2424-2431.

Roers A, Montesinos-Rongen M, Hansmann ML, Rajewsky K, Kuppers R. Amplification of TCRbeta gene rearrangements from micromanipulated single cells: T cells rosetting around Hodgkin and ReedSternberg cells in Hodgkin's disease are polyclonal. Eur J Immunol. 1998;28:2424-2431.

Roopenian D, Choi EY, Brown A. The immunogenomics of minor histocompatibility antigens. Immunol Rev. 2002;190:86-94.

Roullet E. Opportunistic infections of the central nervous system during HIV-1 infection (emphasis on cytomegalovirus disease). J Neurol. 1999;246:237-243.

Russell JA, Brown C, Bowen T et al. Allogeneic blood cell transplants for haematological malignancy: preliminary comparison of outcomes with bone marrow transplantation. Bone Marrow Transplant. 1996;17:703-708.

Russell NH, Hunter A, Rogers S, Hanley J, Anderson D. Peripheral blood stem cells as an alternative to marrow for allogeneic transplantation. Lancet. 1993;341:1482.

Saiki RK, Gelfand DH, Stoffel S et al. Primer-directed enzymatic amplification of DNA with a thermostable DNA polymerase. Science. 1988;239:487-491.

Sarzotti M, Patel DD, Li X et al. T cell repertoire development in humans with SCID after nonablative allogeneic marrow transplantation. J Immunol. 2003;170:2711-2718.

Sarzotti M, Patel DD, Li X et al. T cell repertoire development in humans with SCID after nonablative allogeneic marrow transplantation. J Immunol. 2003;170:2711-2718.

Sarzotti M, Patel DD, Li X et al. T cell repertoire development in humans with SCID after nonablative allogeneic marrow transplantation. J Immunol. 2003;170:2711-2718.

Sarzotti M, Patel DD, Li X et al. T cell repertoire development in humans with SCID after nonablative allogeneic marrow transplantation. J Immunol. 2003;170:2711-2718. 
Schreiber SL, Crabtree GR. The mechanism of action of cyclosporin A and FK506. Immunol Today. 1992;13:136-142.

Schreuder GM, Pool J, Blokland E et al. A genetic analysis of human minor histocompatibility antigens demonstrates Mendelian segregation independent of HLA. Immunogenetics. 1993;38:98-105.

Schwinger W, Mache C, Urban C, Beaufort F, Toglhofer W. Single dose of filgrastim (rhG-CSF) increases the number of hematopoietic progenitors in the peripheral blood of adult volunteers. Bone Marrow Transplant. 1993;11:489-492.

Sebille F, Gagne K, Guillet M et al. Direct recognition of foreign MHC determinants by naive T cells mobilizes specific Vbeta families without skewing of the complementarity-determining region 3 length distribution. J Immunol. 2001;167:3082-3088.

Sebille F, Gagne K, Guillet M et al. Direct recognition of foreign MHC determinants by naive T cells mobilizes specific Vbeta families without skewing of the complementarity-determining region 3 length distribution. J Immunol. 2001;167:3082-3088.

Sebille F, Gagne K, Guillet M et al. Direct recognition of foreign MHC determinants by naive T cells mobilizes specific Vbeta families without skewing of the complementarity-determining region 3 length distribution. J Immunol. 2001;167:3082-3088.

Sebille F, Gagne K, Guillet M et al. Direct recognition of foreign MHC determinants by naive T cells mobilizes specific Vbeta families without skewing of the complementarity-determining region 3 length distribution. J Immunol. 2001;167:3082-3088.

Sebille F, Gagne K, Guillet M et al. Direct recognition of foreign MHC determinants by naive T cells mobilizes specific Vbeta families without skewing of the complementarity-determining region 3 length distribution. J Immunol. 2001;167:3082-3088.

Severino ME, Laulis MK, Horwitz LR, Hess AD. Cyclosporine preferentially inhibits clonal deletion of CD8positive T cells with an MHC class II restricted autoreactive T-cell receptor. Transplant Proc. 1993;25:520523.

Sheridan WP, Begley CG, Juttner CA et al. Effect of peripheral-blood progenitor cells mobilised by filgrastim (G-CSF) on platelet recovery after high-dose chemotherapy. Lancet. 1992;339:640-644.

Siekierka JJ, Hung SH, Poe M, Lin CS, Sigal NH. A cytosolic binding protein for the immunosuppressant FK506 has peptidyl-prolyl isomerase activity but is distinct from cyclophilin. Nature. 1989;341:755-757.

Simpson D. T-cell depleting antibodies: new hope for induction of allograft tolerance in bone marrow transplantation? BioDrugs. 2003;17:147-154.

Small TN, Papadopoulos EB, Boulad F et al. Comparison of immune reconstitution after unrelated and related T-cell-depleted bone marrow transplantation: effect of patient age and donor leukocyte infusions. Blood. 1999;93:467-480.

Smith KA. Interleukin-2. Curr Opin Immunol. 1992;4:271-276.

Smith TJ, Terada N, Robinson CC, Gelfand EW. Acute infectious mononucleosis stimulates the selective expression/expansion of $\mathrm{V}$ beta 6.1-3 and V beta $7 \mathrm{~T}$ cells. Blood. 1993;81:1521-1526.

Smith TJ, Terada N, Robinson CC, Gelfand EW. Acute infectious mononucleosis stimulates the selective expression/expansion of $\mathrm{V}$ beta 6.1-3 and V beta $7 \mathrm{~T}$ cells. Blood. 1993;81:1521-1526. 
Smith TJ, Terada N, Robinson CC, Gelfand EW. Acute infectious mononucleosis stimulates the selective expression/expansion of $\mathrm{V}$ beta 6.1-3 and $\mathrm{V}$ beta $7 \mathrm{~T}$ cells. Blood. 1993;81:1521-1526.

Smith TJ, Terada N, Robinson CC, Gelfand EW. Acute infectious mononucleosis stimulates the selective expression/expansion of $\mathrm{V}$ beta 6.1-3 and V beta $7 \mathrm{~T}$ cells. Blood. 1993;81:1521-1526.

Snell GD. Methods for the study of histocompatibility genes. J Genetics. 1948;49:87.

Solomon SR, Mielke S, Savani BN et al. Selective depletion of alloreactive donor lymphocytes- a novel method to reduce the severity of graft-versus-host disease in older patients undergoing matched sibling donor stem cell transplantation. Blood. 2005.

Soroosh P, Shokri F, Azizi M, Jeddi-Tehrani M. Analysis of T-cell receptor beta chain variable gene segment usage in healthy adult responders and nonresponders to recombinant hepatitis $B$ vaccine. Scand J Immunol. 2003;57:423-431.

Standaert RF, Galat A, Verdine GL, Schreiber SL. Molecular cloning and overexpression of the human FK506-binding protein FKBP. Nature. 1990;346:671-674.

Storek J, Witherspoon RP, Storb R. T cell reconstitution after bone marrow transplantation into adult patients does not resemble T cell development in early life. Bone Marrow Transplant. 1995;16:413-425.

Szilvassy SJ, Humphries RK, Lansdorp PM, Eaves AC, Eaves CJ. Quantitative assay for totipotent reconstituting hematopoietic stem cells by a competitive repopulation strategy. Proc Natl Acad Sci U S A. 1990;87:8736-8740.

Tatari Z, Esperou H, Chastang C, and et al. Influence of donor/recipient HLA-C disparity in 110 unrelated bone marrow transplantation [abstract]. Human Immunology. 1996;47:80.

Thomas E, Storb R, Clift RA et al. Bone-marrow transplantation (first of two parts). N Engl J Med. 1975;292:832-843.

THOMAS ED, Blume KG. Historical markers in the development of allogeneic hematopoietic cell transplantation. Biol Blood Marrow Transplant. 1999;5:341-346.

THOMAS ED, LOCHTE HL, Jr., LU WC, FERREBEE JW. Intravenous infusion of bone marrow in patients receiving radiation and chemotherapy. N Engl J Med. 1957;257:491-496.

Torrelo A, Madero L, Mediero IG, Zambrano A. A cutaneous eruption from G-CSF in a healthy donor. Pediatr Dermatol. 2000;17:205-207.

Troutt $A B$, Kelso $A$. Enumeration of lymphokine mRNA-containing cells in vivo in a murine graft-versushost reaction using the PCR. Proc Natl Acad Sci U S A. 1992;89:5276-5280.

Trowsdale J, Campbell RD. Complexity in the major histocompatibility complex. Eur J Immunogenet. 1992;19:45-55.

Tsuruta Y, Yoshioka T, Suzuki R, Sakata T. Analysis of the population of human T cell receptor gamma and delta chain variable region subfamilies by reverse dot blot hybridization. J Immunol Methods. 1994;169:17-23.

Tsuruta Y, Yoshioka T, Suzuki R, Sakata T. Analysis of the population of human T cell receptor gamma and delta chain variable region subfamilies by reverse dot blot hybridization. J Immunol Methods.

1994;169:17-23. 
Tsuruta Y, Yoshioka T, Suzuki R, Sakata T. Analysis of the population of human T cell receptor gamma and delta chain variable region subfamilies by reverse dot blot hybridization. J Immunol Methods.

1994;169:17-23.

Tsuruta Y, Yoshioka T, Suzuki R, Sakata T. Analysis of the population of human T cell receptor gamma and delta chain variable region subfamilies by reverse dot blot hybridization. J Immunol Methods. 1994;169:17-23.

Tsutsumi Y, Tanaka J, Miura $Y$ et al. Molecular analysis of T-cell repertoire in patients with graft-versushost disease after allogeneic stem cell transplantation. Leuk Lymphoma. 2004;45:481-488.

Tsutsumi Y, Tanaka J, Sugita J et al. Analysis of T-cell repertoire and mixed chimaerism in a patient with aplastic anaemia after allogeneic bone marrow transplantation. Br J Haematol. 2002;118:136-139.

Tsutsumi Y, Tanaka J, Sugita J et al. Analysis of T-cell repertoire and mixed chimaerism in a patient with aplastic anaemia after allogeneic bone marrow transplantation. Br J Haematol. 2002;118:136-139.

Tsutsumi Y, Tanaka J, Sugita J et al. Analysis of T-cell repertoire and mixed chimaerism in a patient with aplastic anaemia after allogeneic bone marrow transplantation. Br J Haematol. 2002;118:136-139.

Tsutsumi Y, Tanaka J, Sugita J et al. Analysis of T-cell repertoire and mixed chimaerism in a patient with aplastic anaemia after allogeneic bone marrow transplantation. Br J Haematol. 2002;118:136-139.

Ueda D, Sato N, Matsuura A et al. T-cell receptor gene structures of HLA-A26-restricted cytotoxic T lymphocyte lines against human autologous pancreatic adenocarcinoma. Jpn J Cancer Res.

1995;86:691-697.

Ueda D, Sato N, Matsuura A et al. T-cell receptor gene structures of HLA-A26-restricted cytotoxic T lymphocyte lines against human autologous pancreatic adenocarcinoma. Jpn J Cancer Res.

1995;86:691-697.

Ueda D, Sato N, Matsuura A et al. T-cell receptor gene structures of HLA-A26-restricted cytotoxic T lymphocyte lines against human autologous pancreatic adenocarcinoma. Jpn J Cancer Res.

1995;86:691-697.

Ueda D, Sato N, Matsuura A et al. T-cell receptor gene structures of HLA-A26-restricted cytotoxic T lymphocyte lines against human autologous pancreatic adenocarcinoma. Jpn J Cancer Res.

1995;86:691-697.

van Bekkum DW. Conditioning regimens for marrow grafting. Semin Hematol. 1984;21:81-90.

van Bekkum DW, de Vries MJ, van der WD. Lesions characteristic of secondary disease in germfree heterologous radiation chimeras. J Natl Cancer Inst. 1967;38:223-231.

van Bekkum DW, Roodenburg J, Heidt PJ, van der WD. Mitigation of secondary disease of allogeneic mouse radiation chimeras by modification of the intestinal microflora. J Natl Cancer Inst. 1974;52:401404.

van der HD, Goulmy E, Falkenburg JH et al. Recognition of minor histocompatibility antigens on lymphocytic and myeloid leukemic cells by cytotoxic T-cell clones. Blood. 1994;83:1060-1066.

Vargas AL, Lechner F, Kantzanou M, Phillips RE, Klenerman P. Ex vivo analysis of phenotype and TCR usage in relation to CD45 isoform expression on cytomegalovirus-specific CD8+ T lymphocytes. Clin Exp Immunol. 2001;125:432-439. 
Vassallo C, Brazzelli V, Alessandrino PE et al. Normal-looking skin in oncohaematological patients after allogenic bone marrow transplantation is not normal. Br J Dermatol. 2004;151:579-586.

Velardi A, Varese P, Terenzi A et al. Lymphokine production by T-cell clones after human bone marrow transplantation. Blood. 1989;74:1665-1672.

Vincenti F. What's in the pipeline? New immunosuppressive drugs in transplantation. Am J Transplant. 2002;2:898-903.

Vissinga CS, Charmley $\mathrm{P}$, Concannon $\mathrm{P}$. Influence of coding region polymorphism on the peripheral expression of a human TCR V beta gene. J Immunol. 1994;152:1222-1227.

von Boehmer H. The developmental biology of T lymphocytes. Annu Rev Immunol. 1988;6:309-326.

von Boehmer H, Aifantis I, Gounari F et al. Thymic selection revisited: how essential is it? Immunol Rev. 2003;191:62-78.

Wang L, Tadokoro $\mathrm{K}$, Tokunaga $\mathrm{K}$ et al. Restricted use of T-cell receptor $\mathrm{V}$ beta genes in posttransfusion graft-versus-host disease. Transfusion. 1997;37:1184-1191.

Warren EH, Greenberg PD, Riddell SR. Cytotoxic T-lymphocyte-defined human minor histocompatibility antigens with a restricted tissue distribution. Blood. 1998;91:2197-2207.

Weaver $\mathrm{CH}$, Buckner CD, Longin $\mathrm{K}$ et al. Syngeneic transplantation with peripheral blood mononuclear cells collected after the administration of recombinant human granulocyte colony-stimulating factor.

Blood. 1993;82:1981-1984.

Willenbrock K, Roers A, Blohbaum B, Rajewsky K, Hansmann ML. CD8(+) T cells in Hodgkin's disease tumor tissue are a polyclonal population with limited clonal expansion but little evidence of selection by antigen. Am J Pathol. 2000;157:171-175.

Willenbrock K, Roers A, Blohbaum B, Rajewsky K, Hansmann ML. CD8(+) T cells in Hodgkin's disease tumor tissue are a polyclonal population with limited clonal expansion but little evidence of selection by antigen. Am J Pathol. 2000;157:171-175.

Willenbrock K, Roers A, Blohbaum B, Rajewsky K, Hansmann ML. CD8(+) T cells in Hodgkin's disease tumor tissue are a polyclonal population with limited clonal expansion but little evidence of selection by antigen. Am J Pathol. 2000;157:171-175.

Wingard JR. Opportunistic infections after blood and marrow transplantation. Transplant Infectious Disease. 1999;1:3-20.

Wucherpfennig KW, Ota K, Endo $\mathrm{N}$ et al. Shared human $\mathrm{T}$ cell receptor $\mathrm{V}$ beta usage to immunodominant regions of myelin basic protein. Science. 1990;248:1016-1019.

Wucherpfennig KW, Ota K, Endo $\mathrm{N}$ et al. Shared human $\mathrm{T}$ cell receptor $\mathrm{V}$ beta usage to immunodominant regions of myelin basic protein. Science. 1990;248:1016-1019.

Wucherpfennig KW, Ota $\mathrm{K}$, Endo $\mathrm{N}$ et al. Shared human $\mathrm{T}$ cell receptor $\mathrm{V}$ beta usage to immunodominant regions of myelin basic protein. Science. 1990;248:1016-1019.

Xun CQ, Thompson JS, Jennings CD, Brown SA, Widmer MB. Effect of total body irradiation, busulfancyclophosphamide, or cyclophosphamide conditioning on inflammatory cytokine release and development of acute and chronic graft-versus-host disease in $\mathrm{H}$-2-incompatible transplanted SCID mice. Blood. 1994;83:2360-2367. 
Yamanaka K, Kwok WW, Mickelson EM et al. Selective T-cell-receptor gene usage in allorecognition and graft-versus-host disease. Transplantation. 1993;55:1167-1175.

Yawalkar N, Ferenczi K, Jones DA et al. Profound loss of T-cell receptor repertoire complexity in cutaneous T-cell lymphoma. Blood. 2003;102:4059-4066.

Yoshioka T, Matsutani T, Iwagami S et al. Quantitative analysis of the usage of human T cell receptor alpha and beta chain variable regions by reverse dot blot hybridization. J Immunol Methods. 1997;201:145-155.

Yoshioka T, Matsutani T, Iwagami S et al. Quantitative analysis of the usage of human T cell receptor alpha and beta chain variable regions by reverse dot blot hybridization. J Immunol Methods. 1997;201:145-155.

Yoshioka T, Matsutani T, Iwagami S et al. Quantitative analysis of the usage of human T cell receptor alpha and beta chain variable regions by reverse dot blot hybridization. J Immunol Methods. 1997;201:145-155.

Zinkernagel RM, Callahan GN, Klein J, Dennert G. Cytotoxic T cells learn specificity for self $\mathrm{H}-2$ during differentiation in the thymus. Nature. 1978;271:251-253. 